Portland State University

PDXScholar

$11-10-2021$

\title{
Letitia Carson in Court: African American Women, Property, and Wages in the Pacific Northwest
}

Stephanie Marie Vallance

Portland State University

Follow this and additional works at: https://pdxscholar.library.pdx.edu/open_access_etds

Part of the African American Studies Commons, United States History Commons, and the Women's Studies Commons

Let us know how access to this document benefits you.

\section{Recommended Citation}

Vallance, Stephanie Marie, "Letitia Carson in Court: African American Women, Property, and Wages in the Pacific Northwest" (2021). Dissertations and Theses. Paper 5866.

https://doi.org/10.15760/etd.7737

This Thesis is brought to you for free and open access. It has been accepted for inclusion in Dissertations and Theses by an authorized administrator of PDXScholar. Please contact us if we can make this document more accessible: pdxscholar@pdx.edu. 


\title{
Letitia Carson in Court:
}

African American Women, Property, and Wages in the Pacific Northwest

$$
\text { by }
$$

Stephanie Marie Vallance

\section{A thesis submitted in partial fulfillment of the} requirements for the degree of

\author{
Master of Arts \\ in \\ History
}

\author{
Thesis Committee: \\ Katrine Barber, Chair \\ Darrell Millner \\ Patricia Schechter \\ Chia Yin Hsu
}

\section{Portland State University}


C 2021 Stephanie Marie Vallance 


\begin{abstract}
Letitia Carson arrived in Oregon from Missouri in 1845, accompanied by David Carson and their newborn child, a daughter named Martha. The Carsons settled in the Soap Creek Valley and took advantage of Oregon's Provisional Government's donation land claim program, living on 640 acres in the newly formed Benton County with Martha and a second child, a son named Adam, born a few years after arriving in Oregon. Within ten years, however, David would be dead and Letitia would be dispossessed of all property and belongings. A former slave, Letitia had little social standing in the new territory and no legal right to inherit David's estate. Yet, Letitia filed suit against the executor of David's estate, asserting agency in defining their relationship - and her own status - on her own terms. In so doing, Letitia revealed the intricacies of a complicated racial and political landscape.
\end{abstract}

David and Letitia's relationship has been difficult to define. He likely owned Letitia as a slave in Missouri. However, he was also the father of her two young children, living and working together on the difficult task of rural homesteading. While he was alive, their relationship was protected by his Whiteness. Seven years after arriving in Oregon, however, David died suddenly, without a will, leaving Letitia and their two children unprotected. The land she lived on and all her possessions were taken from her by Greenberry Smith, a wealthy White landowning neighbor who became executor of the late David Carson's estate. Remarkably, Letitia sued Smith in Benton County probate court in 1853. Claiming she was Carson's employee, she sued for back wages - and won. Letitia's status in relation to David became the center of the court case, and the conflict reveals a complicated and contradictory racial reality in antebellum Oregon. A year later 
Letitia sued Smith again for the loss of her cattle and was victorious a second time. While the first case centered on Letitia's status in relation to David, the second focused on individual property rights. Both cases provide a microcosm that better illuminate the larger debates in Oregon - and nationally - around slavery, land, and labor.

Given the pervasive White supremacy that dominated antebellum Oregon, including notorious Black exclusion laws, it seems unlikely that a Black woman would file suit against a White man at all, let alone win. Analyzing how and why Letitia won her cases illuminates key understandings of early Oregon history and the history of Black women in the West. Though source material on Black women in antebellum Oregon is rare, Letitia Carson's court records survived and analysis of them is critical to developing a nuanced understanding of the political and racial realities of Oregon prior to statehood. Namely, that while even anti-slavery laws at the time were underpinned by nearubiquitous racial prejudice, there existed other structures of power that overlapped and competed to expose cracks in the still-forming racialized landscape. With the help of recent scholarship on race and gender as well as land and labor policy, this thesis maintains that the political debates of the antebellum decades created a specific and unique context in which a White jury may have been sympathetic to a single Black woman. Additionally, this thesis argues that Letitia Carson was successful because of her shrewd legal strategy. She recognized an opportunity and took it, exploiting the cracks in the racialized landscape to demand the right to define herself and determine her destiny. 
To Gomma and Gompa

And to my darling Louisa 


\section{Acknowledgments}

I contemplated a return to graduate school for 13 years before I finally made the leap. I was only two quarters into this master's program when the Covid-19 pandemic became a global reality and life as we knew it changed indefinitely. My experience in graduate school turned out to be vastly different than what I had imagined and from what I had planned. Completing this degree - indeed this thesis - while social distancing and quarantining has been an added challenge for which I was not prepared. I owe many people gratitude for their support and encouragement during this strange time. Without it, I would never have completed this program, much less this thesis.

I was lucky enough to be assigned Dr. Katy Barber as my graduate adviser and she has been an incredible source of inspiration and guidance. I am still in awe of her seemingly never-ending font of knowledge, her professionalism, and her personalized and deeply invested feedback and support of all her students. I reached many points in this thesis journey where I felt stuck, alone, and isolated. I would schedule a meeting with Dr. Barber and would invariably leave feeling inspired, excited, and motivated. Along with Dr. Patricia Schechter and Dr. Chia Yin Hsu, she gave me the confidence to continue when I doubted if I even belonged in graduate school. Seeing their belief in me gave me the courage to believe in myself. Dr. Schechter's intimate seminar courses even over Zoom - allowed me to see public history in action and to develop as an academic thinker and writer. Successfully completing Dr. Hsu's introduction course remains one of my proudest achievements, giving me faith in my own brain and work ethic. I aspire to someday emulate all three of these brilliant women. 
I am in debt to those historians and researchers who have laid the groundwork for my research and generously guided the direction of this thesis paper. Dr. Darrell Milner read the early seminar paper that evolved into this thesis, providing unparalleled expertise and necessary insight into where to take my research. His words still echo in my head and I hope to do them justice here.

A global pandemic meant that archives, libraries, historical museums, and other public research facilities closed their doors, leaving few options for primary research. I thank my lucky stars each day that Dr. Bob Zybach and Janet Meranda dedicated three decades to researching Letitia Carson and then made those records available by digitizing them and providing access to them online. I stumbled upon their repository of scanned documents last year, encountered the incredible Letitia Carson and my life will never be the same. However, even more than that, Bob's kindness and encouragement, his incredible generosity of time and spirit, and his dedication to Letitia have kept me grounded, hopeful, and invigorated. Jan and her husband John drove many miles in the rain to generously hand over physical copies of their files on Letitia and Greenberry Smith, representing decades of hard work, with no questions asked. Her keen eye and attention to detail provided invaluable edits. Larry Landis, Oregon State University archivist and Letitia Carson researcher, also provided valuable insight, knowledge, background, context, and missing primary sources. He offered his support unhesitatingly, and I am very grateful. I am honored to join the ranks of these and the many others working to bring Letitia Carson's story to the public. As I write these words, I am notified that a Corvallis, Oregon elementary school will now be known as Letitia Carson 
Elementary School. This incredible news is in part due to work of the of these dedicated activists.

My late grandfather and grandmother were both historians in their own right, instilling in me a reverence for the past, respect for memory, and the urgent necessity in applying historical lessons in a troubled world. I miss them terribly and wish they were here to read this paper; I hope I make them both proud. My parents are the best in the world and have given me support of all kinds, most of all unwavering faith and boundless love. My mom taught me to love books and to express myself in writing, to question the world, and respond to the despair in it with joy. My dad told me I was an academic when I didn't know it myself. He made me see myself as such and he honored the delight I felt in school. I wouldn't be in graduate school without his words. I hope to one day see myself the way he sees me.

Thank you to my incredible sister, Katie, who listened patiently to every thought, crisis, and breakthrough I've had while attending graduate school and writing this thesis. She kept me company in coffee shops while I wrote, read many drafts of every chapter, and provided a mirror through which I could accurately see my work. She is my best friend, my confidante and without her, I would be lost.

Thank you to my daughter, Louisa, who endured a confusing and scary pandemic with an often-preoccupied mother. Precious are the memories I have of doing online school together, her in kindergarten, me in graduate school, side-by-side. I hope she remembers, too. She is the best girl, my shining light, and the inspiration to me to stay curious, to keep learning, and to be brave, even when you're scared. I love her with all my heart. And to the new little love just beginning to grow: we have been waiting for you 
for so long. Thank you for planning your arrival for the very week this paper was completed. As I close this chapter of my life, I open a new one with such a full heart. And finally, the biggest thanks of all are given to my golden-hearted husband, Adam. He made my dream of graduate school a reality, allowed me to take the huge risk while keeping our family afloat with his generosity and incredible hard work. I will never be able to appropriately thank him for his support, for listening to my ideas, reading my words, and providing feedback with love and insight. His presence in my life is the greatest solace to me, his love the greatest gift, and our home my greatest source of joy. 


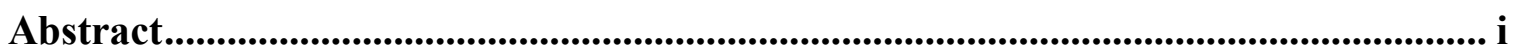

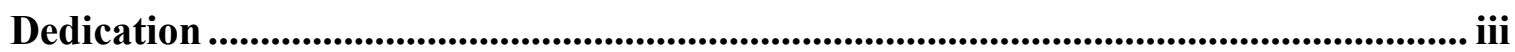

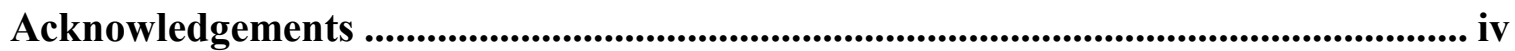

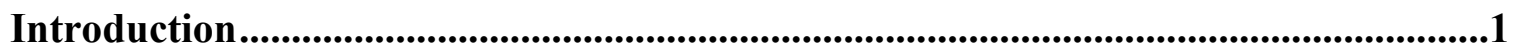

Chapter One: The Court Cases ............................................................................17

Chapter Two: Land and Labor in the West........................................................44

Chapter Three: An Intersectional Strategy ............................................................75

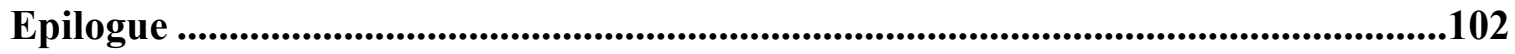

Bibliography .............................................................................................................................108 
"Yet the lives of lesser figures, men and women who lived and died in virtual anonymity, often better illustrate certain aspects of the major issues of a particular period than do the lives of those who, through significant achievement, the appeal of the orator, or the skill of the polemicist, achieve national prominence."

- Melton McLaurin, in Celia, A Slave ${ }^{1}$

\section{Introduction}

In 1854, Letitia Carson, a Black woman living in Benton County, Oregon, sued her white, land-owning neighbor and won. Twice. She had arrived in the Willamette Valley in 1845 with David Carson, a White settler from Missouri. Having likely owned Letitia as a slave in Missouri, David was also the father of Letitia's two young children. The Carsons lived for seven years on a land claim granted by Oregon's provisional government. When David died, their neighbor, Greenberry Smith, used Letitia's one-time status as a slave to dispossess her of her land, her home, and her belongings. Letitia sued Smith as an employee of David Carson, claiming back wages for seven years of uncompensated labor. She won. The next year, she brought a second suit against the same neighbor for the loss of cattle she owned separately from David. Again, the all-White jury sided with Letitia. Given the Black exclusion laws and anti-Black sentiment that dominated Oregon politics during the time, it is remarkable that a Black woman entered a courtroom space at all, much less succeeded in recouping much of what had been taken from her. Upon closer examination, however, the cases reveal valuable insight into the complex, nuanced, and fluid political and social context of antebellum Oregon.

For two decades prior to the Civil War, Oregon's political status was constantly in flux: from the establishment of a flimsy provisional government in 1843 to territorial

\footnotetext{
${ }^{1}$ Melton A. McLaurin, Celia, a Slave (Athens, United States: University of Georgia Press, 1991), ix, http://ebookcentral.proquest.com/lib/psu/detail.action?docID=3038977.
} 
status in 1848 and finally statehood in 1859 , much changed in a short amount of time. Each year, more settlers arrived in the region, bringing with them distinct ideals, beliefs, and attitudes. The political landscape shifted with the arrival of each new wagon train. Debate raged over the role of slavery as well as the rights of free Blacks. Eventually, Oregon joined the Union as the only state to outlaw slavery and exclude any Black people from settling in the state. The duality of the seemingly contradictory laws defined early Oregon statehood. Barring slavery was rarely a moral issue for early Oregonians. Instead, it was firmly rooted in white supremacy, meant in part to create an even playing field for White farmers tired of competing with slave labor. Since racially codified systems of supremacy are based on fundamentally flawed logic and ever-evolving regulations, nothing was set in stone. There existed in antebellum Oregon other structures of power and supremacy which blurred racialized lines and allowed wiggle room for those savvy enough to recognize and exploit it. Letitia Carson's court cases are evidence of the complexity of the formative racialization in early Oregon and the shifting nature of a state whose citizens and residents were still deciding what it would become, illuminated by a Black woman who stepped into the chaos and demanded her own right to selfdetermination.

Letitia Carson arrived in Oregon in 1845 after making the overland journey by wagon train from Missouri. Accompanying her was David Carson, the white man who likely owned or leased Letitia as a slave in Missouri. ${ }^{2}$ She embarked on the difficult

\footnotetext{
${ }^{2}$ There exists no record of sale or lease proving Letitia was enslaved by David. However, there is record of David leasing other slaves in Missouri. Given Letitia and Greenberry Smith's testimony in court, however, it seems they both agreed upon Letitia's enslaved status in Missouri, making it likely David owned or leased her as a slave.
} 
journey pregnant with her daughter, Martha, who was born along the trail. Letitia, David, and their young daughter settled in the Soap Creek Valley on a provisional government land claim of 640 acres. Several years later, in 1849, Letitia gave birth to a son, Adam (later known as Andrew and Jack). When David died without a will in 1852, Letitia and their two young children were left unprotected. Greenberry Smith, a wealthy White neighbor, became the executor of David's estate and immediately seized all land and property, selling it at auction and leaving Letitia and her children homeless. They moved to nearby Douglas County, and the next year she filed suit against Smith and the estate of David Carson.

At the heart of the case was Letitia's status - her role in relation to David - and what she was entitled to based on that status. Was she his slave, his wife (albeit common law) or both? That she didn't claim to be David's wife may seem obvious; marriage across the color line was prohibited, if not formally, then by custom. However, such obvious conclusions demand further examination given that Letitia's presence in court was also prohibited; clearly, what was formally prohibited wasn't necessarily an indicator of what was done. In fact, nearly a decade after David's death, Letitia filed a Homestead Act claim as a widow, prompting many to consider him Letitia's husband. ${ }^{3}$ Questions surrounding her relationship to David are central to this thesis, as they were to Letitia's court cases. Grappling with the relationship between David and Letitia has been a

\footnotetext{
${ }^{3}$ Homestead Act Affidavit for Letitia Carson, June 17th, 1863. http://www.orww.org/History/Letitia_Carson/Documentation/18531922 Douglas_County/18630617_Affidavit.jpg. I owe an incredible debt of gratitude to Bob Zybach, PhD, as well as Janet Meranda, whose research on Letitia Carson has spanned three decades and resulted in the digitization of many Benton County historical documents associated with her life. Given Covid-19 restrictions on visiting the physical archives, I have used these digitized records extensively for this paper. I have accessed them here: http://www.orww.org/History/Letitia_Carson/Documentation/.
} 
significant challenge, as evidenced by my lack of finding a fitting term to refer to David's position in Letitia's life. Titles such as husband, owner, master, and employer likely all contain shades of truth, though in the end, I realized that how Letitia saw herself is essentially unknowable. It also may be less helpful to historians than what we can ascertain from the information that is available to us. I argue later in this thesis that Letitia's decision to claim that she had been David's employee and not his widow was more likely a legal strategy than a reflection of the truth. Working with her lawyer, Letitia would have entered into the lawsuit knowing the inherent risk involved. Her approach tells us a lot about what she felt would resonate with a jury. Her decision to claim an employee's status provides important insight into early 19th-century issues of gender, property, and power.

Smith's central defense against Letitia was that she was David's slave in Missouri and remained enslaved in Oregon. But Letitia sidestepped her former enslavement - and her role as wife or mother - entirely and instead claimed in court a different status that both entitled her to compensation and nodded to the popular anti-slavery tenant of free labor; Letitia claimed to be David's uncompensated employee. Though pro-slavery sentiment certainly existed in Oregon at the time, free labor advocates championed the rights of settlers to work their land without the threat of slavery undercutting their labor prices; their views eventually won out. That her approach worked is evidence of the salience of such ideals in the region still grappling with its identity. It also underscores the reality that though structural racism underpinned the foundation of the territory, other power structures were at play and the machinations of the racist state were not fully functioning. 
Perhaps what is most striking about Letitia's court case is that she won. Oregon's provisional government passed the first Black exclusion law in 1844, just one year after initial governmental organization and the initial prohibition of slavery. ${ }^{4}$ Blacks were required to leave within three years, under punishment of a severe lashing. Though repealed before it was put into effect, it nevertheless illustrated the prevailing attitudes of most white settlers in Oregon: Slavery had no place in the newly settled land, but neither did free Blacks. A second exclusion law was passed four years later, this time leading to the forced expulsion of a Black man from Oregon City, Oregon. ${ }^{5}$ With territorial status came the repeal of previous exclusion laws but the topic didn't die. Slavery itself was still debated in the years leading to statehood, in local newspapers and in the legislature. Eventually the state constitution, approved in 1857 , included an exclusion law, passed with widespread popular support; more Oregonians voted for Black exclusion, in fact, than voted to outlaw slavery. ${ }^{6}$ Though opposition arose, the prevailing attitude in antebellum Oregon was to "consecrate Oregon to the use of the white man, and exclude the negro." ${ }^{7}$ With such blatant state-sanctioned racism, and arduous anti-Black sentiment, the question is begged, how did Letitia Carson win two court cases against a wealthy, white, land-owning man in Oregon in the 1850s? The complicated answer to that central question is the purpose of this thesis.

${ }^{4}$ Elizabeth McLagan, A Peculiar Paradise: A History of Blacks in Oregon, 1788-1940, 1 st ed. (Portland, Or.: Georgian Press, 1980), 26.

${ }^{5}$ Kenneth R. Coleman, Dangerous Subjects: James D. Saules and the Rise of Black Exclusion in Oregon (Corvallis: Oregon State University Press, 2017), 154, http://muse.jhu.edu/book/56398.

${ }^{6}$ K. Keith Richard, "Unwelcome Settlers: Black and Mulatto Oregon Pioneers," Oregon Historical Quarterly 84, no. 1 (1983): 32, https://www.jstor.org/stable/20613888.

${ }^{7}$ Charles Carey, The Oregon Constitution and Proceedings and Debates of the Constitutional Convention of 1857 (Salem, Or.: State Printing Department, 1926), 362. 
I first heard of Letitia Carson while watching “Oregon's Black Pioneers," an Oregon Experience documentary produced by Oregon Public Broadcasting. Intrigued by the remarkable story, I chose Letitia as the subject of a graduate seminar research paper. After finding the records of both court cases digitized and online, I was able to dig deeply into the legal proceedings of Letitia Carson v. Greenberry Smith. Initially, the wrangling over Letitia's status arose as most significant to me. The whole case centered around the debate over who and what she was, and it seemed a perfect microcosm of the external conflict surrounding the case. As Letitia struggled to define her identity for herself, so too, it seemed Oregon struggled to define itself. That remains so, though other themes emerged, complicating the narrative, but impossible to ignore. Letitia doesn't appear in many historical publications, but where she does, she is listed as David Carson's wife. Was it accurate to refer to her as such? Further research suggested that to do so oversimplified extremely fraught and overlapping social and historical issues. Could a marriage as we understand it exist where the relationship of master and slave once existed? Greenberry Smith attempted to define her status for her in court. By labeling her as David's wife, were we doing the same thing, 170 years later? Yet, a document exists in which she referred to herself as David's widow, how might that be accounted for? Eventually, I concluded that an objective truth as to the reality of the intimate relationship between Letitia and David can never be known, and more frankly, might not matter. What remains is a striking amount of source material regarding a Black woman in the West and more important than what conclusions we cannot draw are what conclusions we can. Instead of looking at either her court cases or her later Homestead Act as evidence of how Letitia genuinely saw herself, I reframed her actions in both instances as strategy. It 
can be assumed that when Letitia took the enormous risk of entering the courthouse, a historically unwelcome space for a Black woman, she did so with a calculated plan, choosing the path she - and her lawyer - felt had the highest chance of success. Viewing her court cases through that lens recognizes Letitia's agency as a historical actor in her own right while examining what her strategy illuminates about the social and political landscape of the time.

Clearly, the tactics employed by Letitia were at least partially effective, though other factors contributed to that success. For all the shrewd legal maneuvering on the part of Letitia's legal team, other social and political factors coalesced to create a unique moment in Oregon history where such an unlikely win might be possible. This important context provides a starting point for how Letitia's case could possibly have been sympathetic to a jury of all-white males, who, if they were representative of the majority of the population, would likely have harbored deeply racist beliefs. On the surface, it was easy to see that Letitia's court case centers on her right to define herself, to reclaim her own property and, eventually, to lay claim to her own land. Given the symbolic - and literal - importance of land to settlers in Oregon in 1855 and how fragile those land claims were, it is possible that the juries were primed to hear her case as a reflection of their own unfair treatment.

The importance of land property, the true currency of the west, can only be understood by tracing the history of land claims in Oregon specifically and the importance land played in national politics. Senator Lewis Linn and other early settlers had long been canvassing Congress for legitimate and nationally recognized land claims 
as a reward for westward emigrants who settled the Oregon territory. ${ }^{8}$ Westward settlement in Oregon followed typical settler colonial patterns of laying claim to a desired land by overwhelming it with colonizing bodies. During the 1840s, the Oregon Country was jointly occupied with Great Britain. The Treaty of Ghent, which ended the War of 1812 and was designed to diffuse conflict, allowed both nations to remain in the Oregon Country without giving either nation sovereignty. However, the British owned the Hudson's Bay Company, which made up the largest White population in the region for nearly two decades. ${ }^{9}$ Once American settlers arrived in larger numbers during the $1830 \mathrm{~s}$ and 1840s, joint occupation became far more tenuous. American settlers felt wary given the lack of federal protections in the face of perceived Indian threat and foreign interference. A provisional government was organized in 1843 and a charter drafted. The provisional government hoped to persuade Congress of the need for federal jurisdiction. It also provided 640 acres to every white man, echoing Linn's earlier proposal. ${ }^{10}$ In reality, individual land claims had no federal sanction and therefore lacked legitimacy. As the number of bodies in the region increased, drawn by the promise of land, Great Britain saw their claim on the territory weaken. Eventually, the United States and Great Britain settled the boundary dispute but the region, though no longer under joint occupation, had yet to become a territory. When it gained territorial status in 1849 , all previous land claims were null and void. ${ }^{11}$ That which brought the wagon trains to the region had been ripped from the settlers' grasps. Their claims would be reinstated, though slightly

\footnotetext{
${ }^{8}$ Richard H. Chused, "The Oregon Donation Act of 1850 and Nineteenth Century Federal Married Women's Property Law," Law and History Review 2, no. 1 (1984): 58, https://doi.org/10.2307/743910. 9 John Suval, "The Nomadic Race to Which I Belong: Squatter Democracy and the Claiming of Oregon," Oregon Historical Quarterly 118, no. 3 (September 22, 2017): 312.

${ }^{10}$ Ibid, 319.

${ }^{11} \mathrm{Ibid}, 326$.
} 
amended, in 1850 when Congress passed the Donation Land Claim Act. When Letitia presented her case in court in 1854, Oregonians had experienced the fragility of their hard-fought property rights.

The two court cases brought by Letitia are incredibly important to the history of Black women, and the history of the American West. In the past few decades, historians of the region have worked to correct misleading narratives in which women and people of color were largely absent, save for bit parts as foils or sidekicks. In the latter part of the 20th-century, such omissions were noted, and historians set to work to correct the record. Beginning in the 1990s, "new western history" produced works that provided accounts of the rich and varied lives of Native Americans, Chinese Americans, Mexican Americans, and African Americans. However, many of those attempts amount to simply additive history, most notably in the historiography of Blacks in the US West. Collections of Black pioneer stories were published, offered as proof that Black people existed in and contributed to the settlement of the American frontier.

Yet, Black women in the US West bore a double burden of external control, both because they were women and because they were Black in a place most commonly associated with and attributed to White men. They certainly didn't share the same experiences as White women, and their experiences often differed from Black men. Is placing their experience within the larger pioneer history adequate? Though working to add proof of women who have been systematically erased is important, it can only be seen as a first step toward reframing the understanding of Black women's experiences. In fact, contributionist literature has often colluded in the minimization and homogenization in the Black female experience. Questions of choice, agency, and power differentials 
were initially ignored in favor of the familiar nationalist narrative. Historians know that the lived experience of all westward emigrants was not the same yet used familiar frameworks to treat those experiences as such.

Roger Hardaway’s 1997 article “African-American Women on the Western Frontier" is a good example of the turning point at which scholars identified the need for a separate and unique black women's history but fell short of a meaningful analysis. Hardaway is clear that his goal is contributionist, to include what has been ignored. Providing short biographical accounts of a handful of Black women, Hardaway intends to "alleviate partially this unfortunate situation and make a contribution to the body of work being developed by only a handful of historians."12 His accounts are compelling and certainly achieve the goal of populating the landscape with the lives of women who are routinely erased from it. Hardaway does not offer much in the way of comparative understanding of the women or a framework from which to view the experiences of the women, though his tone tends to follow a similar pattern. Describing the women in a decidedly sympathetic view, Hardaway often refers to their "generosity," "kindheartedness," their charitable work, and also how they were viewed from the perspectives of the White community in which they found themselves. They "earned the respect" and were held in "high esteem" by the larger White community. Indeed, the lives of the women highlighted are remarkable and provide a fuller picture of the contributions of Black women in the region. Yet, it lacks context and succumbs somewhat to a tokenization of Black women with its lack of sophisticated analysis.

${ }^{12}$ Roger D. Hardaway, "African-American Women on the Western Frontier," Negro History Bulletin 60 , no. 1 (1997): 8 . 
More successful contributions, such as Quintard Taylor and Shirley Ann Moore's anthology African American Women Confront the West, 1600-2000 (2008), provide an intersectional lens that examines the complexity of being both a woman and Black. The anthology provides evidence that supports the idea that black women contributed to the formation of the region, "building communities, caring for families, founding and maintaining institutions, and attaining social and economic justice" while possessing a "profound conviction in their own abilities to move beyond the limitations racism and sexism had placed on them."13 Yet, even these analytical contributions span a vast geographic area and time frame. I had great difficulty finding scholarship focused on Letitia Carson's peers specifically: Black women in the antebellum Pacific Northwest.

As Susan Armitage and Deborah Wilbert put it, "The black woman is truly the forgotten person in Pacific Northwest history." " What does exist in Black Western studies centers mostly on the decades following the Civil War, and in urban areas. Indeed, Black women congregated in urban areas of the U.S. West, creating and establishing networks (clubs and churches, for instance) and important scholarship exists about such foundational communities. Much less has been written, however, about the contributions of Black women in antebellum westward settlement, and even less about Oregon specifically. By 1870, Portland boasted a substantial Black community, but less source material is available on Black people in Oregon prior to the Civil War and outside of the urban landscape. There were less than 200 Black residents in the state of Oregon

\footnotetext{
${ }^{13}$ Quintard Taylor and Shirley Ann Wilson Moore, African American Women Confront the West, 16002000, First paperback edition (Norman, Oklahoma: University of Oklahoma Press, 2008), 17.

${ }^{14}$ Susan Armitage and Deborah Gallacci Wilbert, "Black Women in the Pacific Northwest: A Survey and Research Prospectus," in Women in Pacific Northwest History: An Anthology, ed. Karen J. Blair (Seattle: University of Washington Press, 1988),136.
} 
and even fewer Black women during the 1850s, and most of them were employed as domestics servants or laborers. ${ }^{15}$ Written records of their lives beyond census notes are rare. For many years, what was available was overlooked and Black women remained mostly invisible in the story of settlement. According to Armitage and Wilbert, "for black women in rural areas...the sources appear to be too scanty to re-pay the necessary research effort. ${ }^{" 16}$ Certainly, written records of Black women during this era are few and rare. Yet, important sources do exist, such as Letitia Carson's court records, and have yet to be thoroughly examined for what they can illuminate about the lives of the important women whose story remains mostly untold as well as what can be learned about the often-contradictory racial landscape of Oregon's early statehood. The life of Letitia Carson provides historians a glimpse into both.

To revisit, then, the initial central question of Letitia's improbable legal success, it was clear to me that there were key external factors that allowed her case to be sympathetic to a jury of white, male Oregonians in 1854 and crucial strategic decisions that led to her triumph in court. A Peculiar Paradise: A History of Blacks in Oregon, 1788-1940 (1980) provided an initial jumping off point, a helpful overview to which I referred throughout my research. McLagan's description of the importance of popular sovereignty to early Oregon settlers gave life to the connection between Letitia's case and the causes likely most dear to her juries. Several Oregon historians provided key insights to the significance of land in the settlement of the region, including "'The Nomadic Race to Which I Belong: Squatter Democracy and the Claiming of Oregon" (2017), by John

${ }^{15}$ Richard, "Unwelcome Settlers," 37.

${ }^{16}$ Armitage and Wilbert, "Black Women," 45-51. 
Suval and "The Oregon Donation Act of 1850 and Nineteenth Century Federal Married Women's Property Law" (1984), by Richard Chused. I borrow from Kenneth Coleman’s description of the Oregon Donation Land Claim Act in "“We'll All Start Even": White Egalitarianism and the Oregon Donation Land Claim Act" (2019) as an example of how White supremacy functioned in the antebellum Oregon and the long-term impact of free land on generational wealth.

I used Gregory Nokes' book Breaking Chains: Slavery on Trial in the Oregon Territory (2013) on the Robin Holmes court cases as an example of how to place a court case within the larger context of antebellum politics, as well as providing helpful insight into other frontier figures, such as the judge presiding over Letitia's case. The debate surrounding Oregon's future as a slave state mimicked the national conversation and highlighted the hot button of slavery's extension West and into the territories. Jonathan Earle's Jacksonian Antislavery and the Politics of Free Soil (2004) and Stacey Smith's California and the Struggle over Unfree Labor, Emancipation, and Reconstruction (2013) put the closely related issues of Free Soil and Free Labor into the conversation with slavery's extension. Eugene Berwanger's The Frontier Against Slavery: Western Anti-Negro Prejudice and the Slavery Extension Controversy (1967) illuminated how divorced anti-slavery politics were from any widespread support of civil rights.

None of the previously mentioned literature, however, provided any insight into Letitia's personal life or her relationship with David. Peggy Pascoe's What Comes Naturally: Miscegenation Law and the Making of Race in America (2009) and Nancy Cott's Public Vows: A History of Marriage and the Nation (2000) were influential in my understanding of how race and gender functioned in marriage in the early 19th century. 
Both works illuminated the significance of mutual obligation present in both slavery and marriage, lending to my argument that the truth of Letitia and David's relationship was likely reflective of both institutions. Cott's work specifically influenced my understanding of common law marriage and the importance of the larger community in how early marriages were defined.

Building upon these works and others, an explanation emerged as to how Letitia Carson was successful in court in 1850s Oregon: that particular decade was a unique period of time in which her case may have been reflected in the plight of Oregon settlers and she employed the most effective strategy when approaching the court cases. In Chapter One, I outline the two court cases in detail, using the available court records to flesh out a picture of the court proceedings. A striking number of documents survived the 166 years since the first case was filed, though key pieces of testimony have been lost. Much can be gleaned from these records but not everything. Melton McLaurin, author of Celia, A Slave, about a young, enslaved woman who stood trial for killing her sexually abusive master described the impact of such voids. His explanation applies exactly to the way I approached Letitia's case:

Since the significance of [her] story rests in large part upon the manner in which others responded to her, the gaps in the historical record only underscore the historian's difficulty in assessing the motives of those individuals, of determining intent. Assumptions are employed to fill these gaps. Such assumptions are based upon a careful consideration of the record extant, of the historical backdrop against which the events of [her] life played out, and of the past quarter-century of scholarship on slavery. ${ }^{17}$

${ }^{17}$ McLaurin, Celia, a Slave, 12. 
The intent and motivations of individual members of the jury are as unknowable as the inner workings of Letitia's relationship with David. I made assumptions with the benefit of hindsight; two positive verdicts in two years give a jumping off point around which to build scaffolding of likelihoods and educated guesses. Though I don't intend to speak for the members of the jury, in Chapter Two I discuss the external political factors surrounding the case that may have prepared the jury in a sympathetic way. As hardy squatters-turned-settlers, the twelve white men who heard each case would have no doubt been influenced by the biggest issues of their day: land, slavery, and labor. The two court cases between Letitia and Smith centered around those same themes. I address the intersection of context and reality as it relates to power and politics in the West.

While setting and circumstances illustrate the how, Letitia's own actions answer the why. In Chapter Three, I address the choices Letitia made and why they might have led to a victory in court. She claimed a very specific role in court and that decision directed the course of her case and the counterpoint against which Smith created his argument. There was strategy in choosing this role, just as there was strategy in not choosing others. She did not claim a widow's rights, or even the role of a mother. To do so would be fraught with challenges, even if she deserved the benefits of those stations. Trying to prove her womanhood would be to fight an uphill battle, against intersecting forms of oppression, as a woman and as Black person. As historian Deborah Gray White explained, "Black women were unprotected by men or by law, and they had their womanhood totally denied."18 There were laws that prevented formalized marriage across

\footnotetext{
${ }^{18}$ Deborah G. White, Ar'n't I a Woman?: Female Slaves in the Plantation South, Rev. ed. (New York: W.W. Norton, 1999), 12.
} 
the color line, but as I argue later, there existed a vast chasm between what was law and what was done. Relying too heavily on statutes for historical understanding can be shortsighted and misleading, as addressed by historian Diane Somerville. ${ }^{19}$ It doesn't account for the wide variance in public sentiment and action. In the antebellum far West, enforcement of the law could be scattershot, and the opinion of the community was the real gauge for what was tolerated. As I explain in Chapter Three, whatever David and Letitia's relationship was, it would need the approval of their nearest neighbors and community. The members of the jury came from this community, and Letitia and her lawyer would undoubtedly hope to appeal to them.

Throughout this thesis I refer to Letitia by her first name. This is intentional. While I contend that Letitia's true relationship with David Carson cannot be known, I want to recognize her in this paper by her own identity, separate from David. Her right to self-determination was robbed from her, likely many times during her life. I believe she is owed that respect now. Given the likelihood she was at one point owned or leased by David Carson and the common practice of enslaved people taking the last names of their owners, to refer to her as Carson inextricably links her to David. Where I use the name Carson without a first name, I am referring to David. Additionally, I use the 1850 census spelling of Letitia, as well as the spelling of her name on her Homestead Act application, though she is referred to in several places by different spellings, including her gravestone..$^{20}$

\footnotetext{
${ }^{19}$ Diane Somerville addresses the drawbacks of using statutes to understand social thought in both Martha Elizabeth Hodes, Sex, Love, Race: Crossing Boundaries in North American History (New York: University Press, 1999) and Catherine Clinton and Michele Gillespie, The Devil's Lane: Sex and Race in the Early South (New York: Oxford University Press, 1997).

${ }^{20}$ The gravestone, found in Stephens Cemetery in Douglas County, is inscribed with the name "Lutiche Carson."
} 


\section{Chapter One: The Court Cases}

The two court cases brought by Letitia against Greenberry Smith and the estate of David Carson reflect the turmoil and strife that defined the Oregon Territory. In the first case, Oregon's contested status as either free or enslaved is mirrored in the legal debate surrounding Letitia's own status as slave, employee or even wife. In the second, Letitia's status had been established, and as a non-enslaved person, her rights had been violated. Like members of the early Oregon settler classes, she sought to regain control over her livelihood and her valuable possessions. She had proven that she was not property, but rather that she had owned property - valuable property that had been taken from her.

The first court case brought by Letitia addresses most directly the topic of Letitia's status; more specifically her status in relation to David. Since she sued his estate, her position in his life was of the utmost importance. There are three roles Letitia might have possibly filled, though only two were actually mentioned or debated overtly in court: that of his slave or his employee. Her possible role as wife, or even simply as the mother of David's children remained in the background of the court proceedings, never acknowledged in court, despite the frequent mention of their shared children. Instead, Letitia and Smith each identified a role they felt they could use to win. Smith declared her a slave; Letitia claimed she was a servant, an employee. Her status underpinned the case, because the classification determined what, if anything, she was owed. But the case did more than settle a probate conflict; it raised questions that residents of the new territory were still struggling to answer. The biggest question remained: did enslaved status move with a person? What happened when an enslaved person crossed into free territory? Did they move from being a possession to being able to own possessions? The 
cases, a description of which follows, highlight how little precedent had been established in the Oregon Territory in the lead up to the Civil War, how fluid opinions on slavery remained, and how much was yet to be determined. Eventually, Letitia was able to utilize the uncertainty as well as the popular rallying cries of early Oregonians to present a sympathetic case to the juries.

\section{Background}

In 1852, David Carson grew ill and died at the age of 52, leaving Letitia and their two children on their land, but without a will. ${ }^{21}$ It seems he died quite suddenly, without adequate time to prepare his estate and leaving many questions unanswered. ${ }^{22}$ Dying intestate had grave implications for any heir left behind, regardless of race. A will indicated the wishes of the deceased, hopefully limiting questions of intention and providing a neat ordering of property and inheritance. However, from the records of contested wills that remain from the same time period, even the presence of a recorded testament did not guarantee a lack of confusion or conflict. This was especially true when the wills of White men left property or inheritance to women and children across the color line. ${ }^{23}$ As will be discussed later, relationships between White men and Black or Native women were often tolerated while the men were alive, though certainly not encouraged. However, as historian Bernie Jones notes, "in the view of the greater society

\footnotetext{
${ }^{21}$ Greenberry Smith, "Probate Document,” 1852 Benton County Probate Court, http://www.orww.org/History/Letitia Carson/Documentation/18521857 Oregon Probate/18521125 Administrator Smith-1.jpg

${ }^{22}$ Ronald Lansing, author of Nimrod: Courts, Claims, and Killings on the Oregon Frontier, shows David Carson as a member of jury of a murder trial two months before his death. He was dismissed, however, possibly due to illness. Ronald B. Lansing, Nimrod: Courts, Claims, and Killing on the Oregon Frontier (Pullman: Washington State University Press, 2005), 115.

${ }^{23}$ Bernie D. Jones et al., Fathers of Conscience: Mixed-Race Inheritance in the Antebellum South (Athens: University of Georgia Press, 2009), 4. http://ebookcentral.proquest.com/lib/psu/detail.action?docID=3038991.
} 
miscegenation between white men and enslaved women or free women of color was not a problem. Instead, the color line was breached when white men recognized and accorded enslaved women and their mixed-race children status in white society by bequeathing them property and manumitting them."24 Though Jones' research focused on the antebellum South, the same could be said for the far West frontier. While there weren't many Black women in the region at the time, interracial relationships and marriages between White men and Native women were common in the West in the early-19th century. American and European exploration and settlement meant many White men had taken Native wives in the decades prior to Letitia's arrival. Surviving court records show that the White families of deceased men often took issue with contested inheritance rights of those mixed-race widows or progeny. ${ }^{25}$

However, the lack of a will meant Letitia had very little formal claim or any legal recognition. Greenberry Smith, a prominent wealthy landowner and neighbor, was appointed administrator of David's estate in order to make an inventory of the estate and pay all his debts, according to Benton County probate court records. ${ }^{26}$ While the specifics of how he came to be the administrator of the estate are unclear, Smith had prior experience, already having served as executor of his deceased brothers' estate. ${ }^{27}$ Once appointed, Smith made an account of those who stood to inherit; it did not include Letitia - or any of David's biological children. Smith provided testimony that most of Carson's

\footnotetext{
24 Ibid, 2.

${ }^{25}$ Katrina Jagodinsky, Legal Codes and Talking Trees : Indigenous Women's Sovereignty in the Sonoran and Puget Sound Borderlands, 1854-1946, Lamar Series in Western History (New Haven: Yale University Press, 2016).

${ }^{26}$ Greenberry Smith, "Probate Document," 1852.

${ }^{27}$ Wilmer C. Smith, The Smith Chronicle: Two Centuries of an American Farm Family (self-pub., 1973). On loan from the personal collection of Janet Meranda.
} 
family - and therefore heirs - resided in North Carolina, Missouri, and Virginia. It seems David likely had an illegitimate son, David Carson, Jr., who was not listed as an heir but arrived in Benton County in 1851 and made a Donation Land Claim adjacent to Letitia and David. ${ }^{28} \mathrm{He}$ did buy several items at the public auction of David and Letitia's possession, including a pot, some plates and shirts and underwear. ${ }^{29}$ He would later be subpoenaed in the court case. Though Carson also had a son and daughter with Letitia at the time of his death, they were not considered heirs given that they were born outside of recognized wedlock.

The inheritance rights of illegitimate children were limited long before the death of David Carson. From the days of ancient Roman society, children born out of wedlock had been excluded from the rights of legally recognized families. Eventually English common law, with its obsession with Christian morals and its abhorrence of extramarital sexual relations, incorporated the same doctrine. ${ }^{30}$ Known as filius nullius, the doctrine literally translated to "child of no one," giving an illegitimate child no legal right to support from either parent. ${ }^{31}$ As with much of English Common Law, filius nullius was inherited by the American colonies and became American law. In fact, the doctrine was included in every U.S. jurisdiction, save Connecticut. In essence, a child born outside of a

28 "Early Oregonian Person Profile," Oregon Secretary of State Archives Division, accessed August 20, 2021, https://secure.sos.state.or.us/prs/profile.do?ancRecordNumber=94926.

${ }^{29}$ Greenberry Smith, "Estate Sale Record,” 1852 Benton County Probate Court, http://www.orww.org/History/Letitia_Carson/Documentation/1852-

1857 Oregon_Probate/18530104_Estate_Sale-1.jpg

${ }^{30}$ Horace H. Robbins and Francis Deák, "The Familial Property Rights of Illegitimate Children: A Comparative Study," Columbia Law Review 30, no. 3 (1930): 308-29, https://doi.org/10.2307/1115305.

${ }^{31}$ Jay R Petterson, “A Return to Filius Nullius,” North Dakota Law Review 48, no 1 (1971): 59 
legally recognized (read Christian, White, heterosexual) marriage was denied inheritance rights from either their father or mother. ${ }^{32}$

As a filius nullius himself, David Carson, Jr. was unable to lay legal claim to his father's property or possessions. Neither were his half siblings, Martha and Andrew, seven and three at the time of their father's death. Might David have included these children in his will had he made one? It is possible. Free land was a major incentive for those who travelled the Oregon Trail and settled in Oregon, as will be discussed further in Chapter Two. It is important to note that a significant part of that motivation came from the promise of passing on property to future generations. The 640 acres originally granted by the provisional government in Oregon was far too large for individual farmers to utilize fully. Instead, the appeal of a full square mile of rich farmland was the ability to pass on land to progeny, thereby building intergenerational wealth and security. ${ }^{33}$ David Carson, Jr. was able to claim his own land tract with the passage of the Oregon Donation Land Act, and lived for a short while adjacent to Carson, Sr., Letitia and the children, but according to probate and estate records, did not inherit any of his father's property or possessions. ${ }^{34}$

David might have intended to leave property to Letitia and their children. It was not uncommon for White men in the slave-holding South to bequeath property or even to manumit enslaved women they had relationships with and their mixed-race children. Indeed, as long as slavery had existed, so too had sexual liaisons - most commonly forced

\footnotetext{
${ }^{32}$ Ibid, 62.

${ }^{33}$ Cynthia Culver Prescott, "Gender and Generation on the Far Western Frontier," in Women's Western Voices, ed. Laura Woodworth-Ney (Tucson: University of Arizona Press, 2007), 9.

${ }^{34}$ Surveyor General's Office. "Township No 10 South Range No 5 West Willamette Meridian” (Eugene: Surveyor General's Office, 1860).
} 
or coerced - between White masters and the enslaved women who toiled for them. Some of those men left property in their wills to the women they had relationships with and the offspring that were produced. The wills were often contested and the judges who heard the cases had to choose between upholding rights of individual White men and upholding the social orders of slave society. ${ }^{35}$ As Bernie Jones notes, "Free blacks, particularly when they had money, were deemed uncontrollable, arrogant, and a bad influence on the bonded. In the eyes of jurists who ascribed to this view, wealthy free black status was to be denied at all costs, for the benefit of the white social order." ${ }^{36}$ Though a White widow would have inherited a third of her husband's estate by default, regardless of the presence of a will, a judge could deny property or manumission left to enslaved women, even if spelled out explicitly in a White man's will. ${ }^{37}$ Again, even if David had left a will directing his estate to be deeded to Letitia, her perceived status would be the best indication of whether she received it. Given that we know at least one neighbor considered her a slave, it is possible she would have been similarly dispossessed regardless.

Smith was tasked with liquidating Carson's estate. ${ }^{38}$ He quickly seized all property from Letitia and her children in 1852 and very soon after held an estate sale wherein all of David and Letitia's possessions were sold publicly, including livestock, furniture, and tools, as well as such intimate items as the family Bible, books and

\footnotetext{
${ }^{35}$ Jones et al., Fathers of Conscience, 5.

${ }^{36}$ Ibid, 3 .

${ }^{37}$ Ibid, 7.

${ }^{38}$ Greenberry Smith, "Probate Document," 1852.
} 
clothes. ${ }^{39}$ Letitia's property was most likely sold to her neighbors as she watched, given that the estate sale records show that Letitia herself spent $\$ 104$ to buy back some of her own possessions, including a tub, an iron pot, a toilet, plates, a bed and bedding, two cows and one calf; the livestock was the most expensive. ${ }^{40}$ In essence, the estate sale robbed Letitia - and her children - of security, their livelihood, and a future in Benton County. With no home and very few possessions, Letitia took her children and moved south to Douglas County. She did not disappear, however. Over the course of the next two years, Letitia took a powerful and public step to demand recompense for what was taken from her. On February 27th, 1854, Letitia Carson filed a Note of Complaint against Greenberry Smith and the estate of David Carson for "the damages which I have sustained in consequence of the non-performance of the following personal contract made and entered into by and between the said David Carson during his lifetime and myself." 41

\section{The Case}

The initial Notice of Complaint summed up Letitia's entire argument. Her case depended on the personal contract described in the document. According to the notice, David and Letitia entered into the verbal compact "sometime in the months of May or June in the Year AD...while on the road from the state of Missouri to the territory of Oregon and after he had passed the state line of the said state of Missouri..." which

\footnotetext{
${ }^{39}$ Greenberry Smith, "Estate Sale Record," 1853 Benton County Probate Court, http://www.orww.org/History/Letitia_Carson/Documentation/18521857 Oregon_Probate/18530104_Estate_Sale-1.jpg.

${ }^{40} \mathrm{Ibid}$.

${ }^{41}$ Letitia Carson vs. Greenberry Smith, "Carson Complaint," 1854 Benton County Probate Court, http://www.orww.org/History/Letitia_Carson/Documentation/18541857 Carson_vs_Smith/18540227_Complaint_L_Carson-1.jpg.
} 
means that the agreement would have been made within weeks of the birth of Martha, the first child born of the same two parties. As noted in the 1850 census, Martha was born June 9th, 1845 in the "Rocky Mountains."42 According to the deal described, while traveling the rough terrain with a very pregnant Letitia, David "stipulated \& agreed to \& with me that in consideration that I would live with \& work for the said David Carson for and during the term of his natural life that at his decease he would make me his sole heir or that he would give me his entire property which should own or be possessed of at the time of his said decease..." ${ }^{43}$ The significance of the compact was found in the next section. For Letitia stated that "In pursuance of said contract I continued to live with \& work for the said David until the time of his decease."44 Letitia declared clearly that she stayed with David Carson in Oregon because of the promise David made on the trail. To take Letitia at her word means that the inverse might well be true. Had Letitia not been promised to inherit the estate of the propertied White man, she might not have lived and worked for David. Hypothetical scenarios aside, what is clear is that Letitia asserted in court that she and David had entered into a compact of mutual obligation. In truth, the promise to live and work for a man in exchange for security and inheritance resembled more than just an employment contract; it bears striking resemblance to most early 19 th century marriages. Though, as Letitia noted, David "neglected to make me heir to his entire property...by will or otherwise." 45 The lack of documentation meant that she

\footnotetext{
42 "1850 Federal Census of Benton County OR," accessed August 21, 2021, http://genealogytrails.com/ore/benton/census/1850/18501.html.

${ }^{43}$ Carson vs. Smith, "Carson Complaint," 1854.

${ }^{44}$ Ibid.

${ }^{45}$ Carson vs. Smith, "Carson Complaint 2," 1854, http://www.orww.org/History/Letitia Carson/Documentation/18541857 Carson_vs_Smith/18540227 Complaint_L_Carson-2.jpg.
} 
"sustained great damage to wit five thousand dollars," enumerating the damages as follows: ${ }^{46}$

$\begin{array}{lc}\text { Damages on contract } & \$ 5000.00 \\ \text { To } 7 \text { years } 5 \text { months labor at } \$ 400500.00^{47} \text { per year } & 3750.00 \\ \text { " } 29 \text { head of Cattle at } \$ 50.00 \text { per head } & 1450.00 \\ \text { " the use of } 10 \text { cows } 7 \text { years } & 1000.00\end{array}$

The amount demanded by Letitia totaled $\$ 11,200$. According to a New York University Law School Publication, the intended purpose of awarding damages on contract is to "put promisee in position he would have been in had the contract been performed." ${ }^{48}$ Had the contract been completed as Letitia expected, she would have been the recipient of all of David's land, property, and possessions. According to the verbal contract they made, David believed such compensation was commensurate for the work Letitia would perform upon arrival in Oregon. It was not an arrangement typically made with enslaved people.

The other charges against David Carson's estate are specific and important. Letitia claimed back wages, and in doing so, both claimed for herself the role of an employee and put a value on her labor, work that an enslaved person (nor a wife) would have been paid for. Greenberry Smith quickly responded, countering that she was in fact David's slave, and therefore owed nothing for the work she performed. Indeed, the crux of the matter lay with whom the jury would agree.

\footnotetext{
${ }^{46}$ Ibid.

47 The strikeout of $\$ 400$ and the change to $\$ 500$ is included in the original document.

48 "Damages for Breach of Contract," n.d., 65, accessed August 21, 2021, https://www.law.nyu.edu/sites/default/files/ECM PRO 063763.pdf.
} 
Letitia likely made her legal decisions in conference with her lawyer, Andrew Thayer. Letitia lived in Douglas County during the court proceedings and therefore was represented by Thayer many times. Andrew Jackson Thayer had only recently arrived in Oregon when he took on Letitia's case. He grew up and went to law school in New York and arrived in Oregon in 1853 with his brother. After the Carson trial, he went on to become an influential figure in Oregon law and politics. He was a circuit court judge, he was elected to Congress in 1860 and later served on the Oregon Supreme Court. ${ }^{49}$ Though no evidence remains for why Thayer decided to defend Carson in his new home, his obituary described him as "unwavering in his political faith" as a life-long Democrat, "conscientious in his decisions" as a judge, and "true to the people" as a citizen. ${ }^{50}$

Regardless of why Thayer took Letitia's case, he no doubt played an important role in designing the approach to the case.

\section{Greenberry Smith Responds}

Smith was served the notice the following day, according to court documents, and responded to the notice by calling into question the legal standing of all of Letitia's claims. ${ }^{51}$ Seemingly set on undermining the legitimacy of the complaint itself, Smith's lawyer, John Kelsay, refuted the claimed damages. With nary a comma in a long list of complaints, Kelsay declared that Letitia's complaint was 'not entitled of any court,' that it wasn't clear in which court she was bringing the action anyway, that 'it doth not appear in...the said declaration who the plaintiff is in said suit,' that the causes of action didn't

\footnotetext{
${ }^{49}$ Andrew Thayer obituary. 1873. Albany Democrat, May 2, 2.

${ }^{50}$ Ibid.

${ }^{51}$ Letitia Carson vs. Greenberry Smith, "Notice to Greenbury Smith,” 1854 Benton County Probate Court, http://www.orww.org/History/Letitia Carson/Documentation/18541857 Carson_vs_Smith/18540228_Notice_Smith.jpg.
} 
appear to be within the jurisdiction of the probate court. The statement goes on to call into question every "count" raised by Letitia's notice of complaint. Where had she gotten the cattle she claimed were hers? When exactly was the labor done? At the heart of the four-page statement, Smith and his lawyer allege that Letitia and her lawyer hadn't shown how David was indebted to Letitia "nor when said indebted ness accrued, nor when nor where the said administrator was indebted to the said Lutertia Lutersha Carson and for that the said last mentioned counts are uncertain and obscure. ${ }^{" 52}$ Smith and his lawyer employed a kitchen sink strategy throughout the court proceedings, running through many tactics to test whichever defense might stick. Initially, it seems their approach was to undermine the legality of Letitia's claims; in essence, to fight her with red tape, casting doubt on her legitimacy and stopping the suit before it had begun.

In addition to dismissing Letitia's suit, Smith's response used a wide array of spellings of Letitia's name. Within the single document, Kelsay referred to Lutersha, Lutisha, and Lutensha. For the remainder of the court case, however, many more versions of her name appeared. Smith's lawyers weren't the only ones who took liberties with the spelling. The county clerk even issued subpoenas in the case listing her name as Lucretia. While spelling conventions were still becoming streamlined and standardized, and others were misspelled in court documents including Greenberry himself, no effort seemed to have been made to identify and use one single way of referring to her. ${ }^{53}$ The vast array of spellings, even among the same document, is worth noting, for it reflects the confusion

\footnotetext{
52 Letitia Carson vs. Greenberry Smith, "Kelsay Statement," 1854 Benton County Probate Court, http://www.orww.org/History/Letitia Carson/Documentation/18541857 Carson vs Smith/18540300 Kelsay Statement-1.jpg.

${ }^{53}$ Court documents often use "Green B Smith" instead of Greenberry. Even "Green Bery” once.
} 
over her status. Seen as property, an enslaved person would not have had a legal name, instead being called whatever their current master pleased. Her own signature on court documents is an "X," commonly used by those unable to read or write and indicating her own inability to monitor the written spelling of her name.

\section{Subpoenas issued}

Smith and Kelsay's objections to Letitia's claims didn't seem to sway the court, as the proceedings continued with subpoenas issued the next week on Smith's behalf. Among those subpoenaed was Andrew Carson, a nephew of David who arrived in the region in 1851 from North Carolina, and David Carson, Jr., likely David's illegitimate son. Smith must have been confident that the testimony of the two men would help his case, which soon rested on proving to the court that Letitia had been David's slave. However, Andrew Carson proved to be "Not found in the County," according to the county sheriff. ${ }^{54}$ Indeed, an 1854 tax roll shows A J Carson in neighboring Lane County. ${ }^{55}$ In the meantime, other subpoenas were issued and though the records indicate that the subpoenas were delivered - either "Personally Served By delivering a copy" "served personally by reading," 57 no record of testimony or deposition remains for most of them (the exception being in the second case brought by Letitia the following year). A

\footnotetext{
${ }^{54}$ Letitia Carson vs. Greenberry Smith, "Bill for Andrew Carson Subpoena," 1854 Benton County Probate Court, http://www.orww.org/History/Letitia_Carson/Documentation/1854-

1857 Carson_vs_Smith/18540313 Subpoena_A_Carson_Bill.jpg.

${ }^{55}$ Lane County Assessment Rolls, Lane County Historian XII, no. 3 (1967): 73.

A valuation for tax purposes shows his property to be worth $\$ 165$.

${ }^{56}$ Letitia Carson vs. Greenberry Smith, "Walker Deposition Bill," 1854 Benton County Probate Court, http://www.orww.org/History/Letitia_Carson/Documentation/1854-

1857 Carson vs Smith/18540327 Walker Deposition Bill.jpg.

${ }^{57}$ Letitia Carson vs. Greenberry Smith, "Subpoena Writsman, et al," 1854 Benton County Probate Court, http://www.orww.org/History/Letitia_Carson/Documentation/18541857 Carson_vs Smith/18541009 Subpoena Writsman et al.jpg.
} 
recent email conversation with a Processing Archivist at the Oregon State archives confirmed that the existence of such specific documents in archived files is rare. ${ }^{58}$ Yet, the subpoenas issued on both sides provide helpful insight into strategy.

For her part, Letitia had two men subpoenaed whose depositions were crucial to her case: Henry William Knighton and William Walker, neither of whom could be found in the county, either. Letitia's lawyer, Andrew Thayer, however, outlined to the court the importance that Knighton and Walker held to the case. Thayer had proof, he claimed, that Knighton, who came across the Oregon trail in the same year as the Carsons, had sold a cow to David and that David had told Knighton he was buying the cow for Letitia, with her own money. Walker, on the other hand, could prove that the rest of the cattle taken as a part of David's estate (29 head of cattle) all descended from that same cow, making the whole herd Letitia's own property. The testimony of both Knighton and Walker was central to Letitia's original claim that she was owed the value of the cows that had been wrongly taken from her. Neither material witness, however, could be located.

Additional subpoenas issued on behalf of Greenberry Smith included neighboring landowners Francis Writsman, Alfred Writsman, Joseph Hughart and John Wiles. ${ }^{59}$ Along with Smith, all four men owned land claims in the immediate vicinity of David Carson's claim. ${ }^{60}$ They would have been some of the closest neighbors of Letitia and David, signalling perhaps that Smith counted on their close proximity as reliable sources

\footnotetext{
58 Todd Shaffer, email message to author, May 3, 2021.

${ }^{59}$ Interestingly, Hughart had been employed by David Carson's estate to appraise his property prior to either court case. He was also Smith's brother-in-law, as Smith's second wife was Mary Hughart, brother to Joseph. "Appraiser Statements," 1852 Benton County Probate Court, http://www.orww.org/History/Letitia_Carson/Documentation/18521857 Oregon Probate/18521207 Appraiser Statements.jpg

${ }^{60}$ Surveyor General's Office. “Township No 10 South Range No 5 West Willamette Meridian” (Eugene: Surveyor General's Office, 1860).
} 
of information on the nature of Letitia and David's life in Benton County. If he was to prove that David saw Letitia as his slave, he would need to provide evidence from those who knew him well.

\section{Amended Labor Bill}

Much of Letitia's strategy revolved around harnessing the popular demand of early Oregonians for free labor. Discussed further in Chapter Two, free labor was the goal for most anti-slavery settlers. Underpinning what would later become the Republican party, the ideology of free labor was more than just a political preference. As Eric Foner writes, it "expressed a coherent social outlook, a model of the good society." ${ }^{61}$ Free labor proponents in Oregon and around the nation sought to distinguish themselves from the Southern slave-holding way of life and to clear the way for hard working (White) men. It "was an affirmation of the superiority of the social system of the Northa dynamic, expanding capitalist society, whose achievements and destiny were almost wholly the result of the dignity and opportunities which it offered the average laboring man. ${ }^{" 62}$ Free labor ideology was not intended to bolster opportunity for people like Letitia. However, its widespread support meant that to ignore her demand for payment would have been a denial of free labor and a tacit approval of slavery in the region.

In July of 1854, Letitia submitted a revised bill for her labor. For whatever reason, she amended her prior claim of $\$ 500$ a year for labor to only $\$ 200$ a year, for a total of $\$ 1500$, a significant reduction from her original claim of $\$ 3750$ for seven and a half years

\footnotetext{
${ }^{61}$ Eric Foner, Free Soil, Free Labor, Free Men: The Ideology of the Republican Party Before the Civil War (Cary, United States: Oxford University Press USA - OSO, 1995), 11, http://ebookcentral.proquest.com/lib/psu/detail.action?docID=694007.

62 Ibid.
} 
of labor. Apparently, Letitia and her lawyer felt their initial claim to be too high. Indeed, the back wages she demanded would need to be accepted as reasonable to a jury of her fellow Benton County residents in order for them to side with her. Her initial complaint asserted that she expected to receive the entirety of David's estate upon his death, but since the contract was not upheld without a will, she expected to be paid as an employee, a servant who "performed meneal [sic] service." ${ }^{63}$ Such staff were regularly employed in American households at the time, even in far-flung territories such as Oregon. Finding comparable wages is crucial for placing Letitia's labor bill in context. In 1848, the Commissioner of Patents compiled national average wages for many different trades and positions. For female domestic servants, the average monthly wages were $\$ 4$ to $\$ 6$ for whites and $\$ 3$ to $\$ 5$ for enslaved laborers. ${ }^{64}$ However, those figures include room and board, which was an integral part of the pay of many domestic servants around the nation. Letitia refers to work and labor and services many times throughout the case, but there is no mention of the exact tasks she completed. Therefore, it is difficult to place the wages demanded by Letitia in a more precise context. $\$ 500$ a year - indeed $\$ 200$ even - is much higher than the national average wage for a domestic servant with board in 1848 .

Letitia's amended labor bill made allowances for board, perhaps to better reflect the going rates for domestic service, or perhaps to proactively thwart Smith's defense that room and board constituted ample payment. By signing her "X" on the amended deposition, Letitia agreed that a $\$ 500$ allowance could be made for the room and board

\footnotetext{
${ }^{63}$ Letitia Carson vs. Greenberry Smith, "Response Thayer," 1854 Benton County Probate Court, http://www.orww.org/History/Letitia_Carson/Documentation/18541857 Carson vs Smith/18541011 Response Thayer-1.jpg.

${ }^{64}$ United States et al., Wholesale Prices, Wages, and Transportation. Report by Mr. Aldrich, from the Committee on Finance, March 3, 1893., 52d Cong., 2d Sess. Senate. Rept. 1394 (Washington: Govt. Print. Off., 1893), https://catalog.hathitrust.org/Record/001309548.
} 
and clothing provided to the children, leaving only $\$ 1,000$ demanded of Smith, a significant cut from the original claim of $\$ 11,200 \cdot{ }^{65}$ Of course, without the testimony of Walker and Knighton, the claim to the cattle was difficult to prove, and mention of the cattle was dropped from the proceedings. Additionally, without written evidence of or witnesses to the original alleged contract between David and Letitia, damages to said contract were perhaps unsupportable. For the rest of the first court case, Letitia's status and her uncompensated labor remained the center of the proceedings.

\section{Thayer Testifies}

Greenberry Smith's defense lay in proving Letitia's slave status and so again denied even her starkly reduced claim. Two months later, Thayer issued more subpoenas and filed another complaint for the modified amount. Those summoned to testify on behalf of Letitia included Thomas Read, David Davis, Jehial Kendall, Joseph Hughart, Archimedes Stewart, all of whom were fellow 1845 overlanders. ${ }^{66}$ David Davis, in fact, owned the land claim that directly abutted Carson's to the North. If Smith had neighbors who could provide evidence for his stance that Letitia was a slave, it seemed Letitia had just as many who could prove that she was a servant.

Thayer's amended complaint makes no mention of the verbal agreement between David and Letitia or the 29 head of cattle. Instead, he denies Smith's assertion that Letitia is a slave and instead emphasizes her role as laborer and the work done over seven and a half years and that "said work labor \& services were reasonably worth the just $\&$ full sum

\footnotetext{
${ }^{65}$ Letitia Carson vs. Greenberry Smith, "Letitia Carson Labor Bill," 1854 Benton County Probate Court, http://www.orww.org/History/Letitia Carson/Documentation/1854-

1857 Carson vs Smith/18540712 L Carson Labor Bill.jpg.

${ }^{66}$ Stephenie Flora. "Oregon In 1845.” Accessed August 21, 2021.

http://www.oregonpioneers.com/1845.htm.
} 
of one thousand dollars... ${ }^{67}$ Also issued the same day as the simplified complaint was a subpoena for Smith, summoning him to court in October. The subpoena included the important reminder that he must "appear and answer the complaint," for "the plaintiff will take judgment for the sum of one thousand dollars $(\$ 1000.00)$ if the defendant fails to answer the complaint." ${ }^{\prime 68}$

Thayer also submitted an affidavit on Letitia's behalf on the same day, given that she resided outside of the county. His deposition backed up Letitia's complaint, swearing his own belief that her claims regarding her status were founded in truth. That belief, Thayer swore, "is founded upon information derived from different individuals residing in said county \& who crossed the plains during the summer of AD 1845 and saw said plff at work for said Carson \& have known of her working for said Carson until the time of his death which took place during the Spring of AD 1853...” Those same overlanders also informed Thayer that they agreed "that said work \& labor was worth the sum of one thousand dollars." ${ }^{69}$ The testimony of their neighbors likely was important in proving that Letitia was seen by David as his laborer. If the jury agreed, then she was entitled to possession of property. Smith was determined to prove that she was entitled to nothing because, as a slave, she was herself property.

\section{Smith Responds}

\footnotetext{
${ }^{67}$ Letitia Carson vs. Greenberry Smith, "Letitia Carson Complaint,” 1854 Benton County Probate Court, http://www.orww.org/History/Letitia_Carson/Documentation/18541857 Carson_vs_Smith/18540922_L_Carson_Complaint.jpg.

${ }^{68}$ Letitia Carson vs. Greenberry Smith, "Subpoena Greenberry Smith," 1854 Benton County Probate Court, http://www.orww.org/History/Letitia_Carson/Documentation/1854-

1857 Carson vs Smith/18540922 Subpoena GB Smith.jpg.

${ }^{69}$ Letitia Carson vs. Greenberry Smith, "Thayer Testimony," 1854 Benton County Probate Court, http://www.orww.org/History/Letitia_Carson/Documentation/18541857 Carson_vs Smith/18540922 Testimony Thayer.jpg.
} 
In October of 1854, Greenberry Smith did appear in court to attempt to prove his assertions about Letitia's status. He laid out his argument in five points. First and foremost, Smith denied Letitia's claim that she was Carson's unpaid employee. Instead, Smith argued, she left Missouri as Carson's slave and was still his slave until he died. Specifically, he made sure to note that the two Carsons remained "up to the time of the death relation of master and slave." With that counterclaim, Smith grounded his argument: As a slave, she was due no back wages. Apparently, Smith didn't trust that his defense was strong enough. He followed up his own declaration by hedging his bets. Even though Smith contended that Letitia had been fairly and adequately recompensed as a slave, he still refuted the quantification she placed on her labor. Despite heartily denying her right to payment, he asserted that even if she had been an employee, the services performed were not "reasonable worth $\$ 1,000 . " 70$

Tellingly, Smith also invoked common pro-slavery language when he also told the court that Letitia resided with the late Carson as "one of his family." " Smith's description of the Carson "family," illustrated the popular sanitized view of slavery as one of benevolent paternalism where those enslaved were cared for by their master in exchange for obedience. In his response, Greenberry Smith insisted that as a slave, Letitia had been adequately compensated and that the clothing and housing Carson provided for her and her children was "reasonable worth as much as her labor and work." ${ }^{, 72}$ In other words, according to Smith, the relationship of mutual obligation was fulfilled on both

\footnotetext{
${ }^{70}$ Letitia Carson vs. Greenberry Smith, "Greenberry Smith Answer," 1854 Benton County Probate Court, http://www.orww.org/History/Letitia_Carson/Documentation/1854-

1857 Carson_vs Smith/18541010_Answer_GB Smith-1.jpg.

${ }^{71}$ Ibid.

${ }^{72}$ Ibid.
} 
sides, nothing was owed or due. Despite the claims to family, however, Martha and Andrew were referred to as "the children" or "her children," the second and third children apparently born to David, a man whose estate described him as childless.

Again, Smith took a different tack. Despite maintaining that nothing was owed to Letitia due to her enslaved status, Smith told the court that her emancipation upon David's death was worth more than the price she demanded of the estate. Smith's apparent legal interpretation appeared to be that slaves brought to the new territory maintained their enslavement status until the death of their master, when they were emancipated by the territory's antislavery law. The questions surrounding when and if an enslaved person was considered free after visiting a free territory was a central preoccupation of the entire nation at the time. In 1857, just a couple years after Letitia's case, the Dred Scott decision would answer this very question at a federal level, rocking the nation. Declaring that Blacks could never be citizens, even if free, and that Congress did not have the authority to prohibit slavery in the territories, the decision did little to quell sectionalist tension, instead hurtling the nation closer to war. ${ }^{73}$ At the time of the court case, however, consensus of when and if freedom could be gained by migration had not been reached. Smith's analysis seemed to deny that a slave could gain their freedom by anything other than their master's death.

To define Letitia's status, the perspective of her immediate community was essential. Both sides sought to prove that those who knew Letitia best knew the truth. Smith's testimony echoed the same language used by Thayer in his previous affidavit,

\footnotetext{
${ }^{73}$ Timothy S. Huebner, “'In Defiance of Judge Taney': Black Constitutionalism and Resistance to Dred Scott," Journal of Supreme Court History 45, no. 3 (2020): 222, https://doi.org/10.1111/jsch.12245.
} 
asserting "that he is informed by persons who knew said Carson Decease in Missouri \& in crossing the plains that plaintiff was a slave \& belonged to said Deceased."74 The testimony of their fellow community members was critical for both sides, as both Thayer and Smith claimed to have definitive proof of Letitia's status from those who travelled the Oregon Trail with her. Though no testimony exists, Thayer seemed to have witnesses who saw Letitia as David's servant, while Smith's informants believed Letitia to be enslaved by David. That everyone was telling the truth isn't out of the question. Likely fellow travellers assumed many different things about their relationship; likely many of them were right. It is reasonable to assume that the truth was blurry and difficult to define, resisting the compartments that others tried to place them in.

Smith's argument ended with what seemed like the last remnants of a stretched defense. He included a description of multiple periods wherein Letitia was unable to work for David due to health reasons. Smith testified that Letitia was too sick to work or "even to wait upon herself" during one of these times and that David "waited upon" her and "employed \& paid for her medical attendance at the instance and request of plaintiff." 75 The other period referred to the birth of their second child, wherein David paid for her to be boarded until she was "delivered of a child \& recovered."76 Therefore, Smith along with "the boarding clothing of plaintiff \& her children" and "the trouble \& expense of bringing her across the plains," "the attention bestowed upon her during her sickness" was above and beyond any compensation any slave was owed. That the

\footnotetext{
${ }^{74}$ Letitia Carson vs. Greenberry Smith, “Answer Greenberry Smith,” 1854 Benton County Probate Court, http://www.orww.org/History/Letitia_Carson/Documentation/18541857 Carson_vs Smith/18541010_Answer_GB Smith-1.jpg.

${ }^{75} \mathrm{Ibid}$.

${ }^{76}$ Ibid.
} 
children she bore and delivered were David's own was not mentioned. Smith ended his testimony with a sensational claim: he could prove Letitia's enslaved status because he had a bill of her sale to David. Such documents were never produced, however. ${ }^{77}$

\section{Letitia Responds}

Thayer quickly filed a motion to strike from the court record Smith's assertion that Letitia was David's slave in Missouri as it was "irrellivant [sic] and constitutes no defence $\left[\right.$ sic]. ${ }^{978}$ Seemingly Letitia did not seek to disprove she had been enslaved in Missouri, simply that she was no longer such when they got to Oregon. Thayer also asked that the court strike out Smith's assertion that emancipation was worth the labor Letitia performed as it was "pleading by implication and constitutes no defence [sic]." ${ }^{.79}$ Thayer appeared to call Smith out for creating a false equivalence between labor performed and emancipation, with no precedence mentioned. Both points remained visible on the document that remains. ${ }^{80}$

Evidence remains, however, that Thayer may have been successful in striking those points. Letitia and Thayer submitted a response to Smith's argument, addressing each of his five points and affirming her labor's worth at $\$ 1,000$. Though it originally included responses to the two points Thayer sought to remove, two responses have been crossed out: "that she denies that from the year 1845 she has remained a slave of said David Carson deceased up to the time of his death..." and that "...she further denies that the emancipation of said Plaintiff was reasonable worth as much as any labor she did for

\footnotetext{
${ }^{77}$ Ibid.

${ }^{78}$ Letitia Carson vs. Greenberry Smith, "Motion Thayer," 1854 Benton County Probate Court, http://www.orww.org/History/Letitia_Carson/Documentation/18541857 Carson_vs Smith/18541007_Motion Thayer.jpg.

${ }^{79}$ Ibid.

80 “Answer Greenberry Smith,” 1854.
} 
the defendeant $[\mathrm{sic}] . . . ”$ That they appear stricken may be proof that Thayer was successful in removing Smith's irrelevant arguments.

The same document maintained her labor's worth, but also made an important distinction about her role. Letitia directly and succinctly denied Smith's classification of her relationship with David. She denied "that she lived and continued to reside in the family of said David Carson decd as one of his family merely." Rather, she "avers that she resided in said family as a servant and performed meneal [sic] service as such during said period mentioned." Letitia dismissed Smith's allusions to the slave "family" and declared to the court her own definition of who she was: a servant. Put another way, Letitia asserted the right to determine her own status. Taken at her testimony, Letitia clearly stated that she did not consider herself David's family; rather, she saw herself as his employee. The case, therefore, came down to a very basic question. Would the jury see her as a slave (and therefore already overcompensated), or as a servant and therefore wrongly dispossessed of that which was rightly due.

\section{The Cause Continued}

Eventually, the case hit an impasse. With final arguments laid out, the jury was unable to reach unanimity. The Oregon Statesman reported (in the only real media coverage of the case) that in "...the absence of circumstances that could imply an agreement to pay," the jury was split. Nine members of the jury sided with Letitia and three with Smith. The jury was discharged, and the cause continued. The Statesman, however, seemed to side with Letitia. "This was an action by a black woman to recover the value of her services rendered in this territory to defendant from the year 1845 to 1852. Luteshia was a slave in Missouri but came to Oregon and served her master 
faithfully until his death." ${ }^{81}$ The Statesman was not a publication typically sympathetic to the plight of freed slaves, or any Blacks for that matter. Indeed, the next year the same newspaper would report on a conference of abolitionists that "A collection of old grannies held an abolition meeting in Albany," aghast that "n------ struck dames" wanted the Statesman "to publish their stale fanaticism" noting that the same abolitionists wanted the Statesman "to fill our columns with a batch of Fred Douglasisms, which the sensible men who do patronize and sustain the paper don't wish to see." ${ }^{" 82}$ Yet, the same publication which derided abolitionists as fanatics saw no inconsistency in supporting Letitia in seeking payment for services, despite Smith's insistence that her status as slave precluded her from payment.

\section{A Decision}

The next Spring, after both sides called more witnesses, a new jury came to a consensus. On May 7th, 1855, Benton County courts convened under Judge George Williams and the jury of 12 White Benton County male residents arrived at a verdict. "We the jury," read the judgment, "for the Plaintiff the sum of three hundred dollars." In addition to the award, the judge ordered Smith to pay Letitia's court fees, which totaled nearly as much. In all, the estate of David Carson owed Letitia the following ${ }^{83}$ :

$\begin{array}{lr}\text { Judgment } & \$ 300.00 \\ \text { Sheriffs fees } & 29.00 \\ \text { Clerks fees } & 27.10 \\ \text { Witness fees } & \mathbf{1 6 6 . 1 0} \\ \text { Total } & \$ 522.20\end{array}$

\footnotetext{
81 "District Court Benton County," The Oregon Statesman, Oct. 17, 1854.

82 "Cool!" The Oregon Statesman, July 14, 1855.

${ }^{83}$ Letitia Carson vs. Greenberry Smith, "Judgment Bill," 1855 Benton County Probate Court, http://www.orww.org/History/Letitia_Carson/Documentation/18541857 Carson_vs_Smith/18550624_Judgment_Bill.jpg.
} 
Though a far cry from the $\$ 11,200$ Letitia initially petitioned, the victory paved the way for her second court case. Letitia did not take her settlement and fade into Douglas County. Seemingly emboldened by the win, she returned to Benton County courts to insist upon her right to further compensation. When her status had been in question, it wasn't clear if she had a right to any possessions. Now that the court had determined she was a free laborer, rather than a slave, she was able to tackle the matter of her cattle.

\section{The Second Case}

While the first suit brought against Greenberry Smith centered on Letitia's status and relationship to David, the second case focused on her individual property rights. Unable to provide adequate evidence in the first case of her rightful claim to the 29 head of cattle, she dropped her demand for their compensation. Yet, two months after her victory in court, Letitia's lawyer, Andrew Thayer, filed a second complaint in Benton County on Letitia's behalf, reasserting her entitlement. According to the complaint filed in August 1855, Letitia "was lawfully possessed \& owned twenty nine head of cattle consisting of cows heifers, steers, \& calves" which were worth "the just $\&$ full sum of two thousand dollars." Thayer asserted that Smith "took said cattle \& converted them to his own use contrary to the will \& against the consent of said plff." $" 84$ Thayer contended that his knowledge of the case derived "from individuals who resided near said plff" and affirmed the aforementioned claims, again underscoring the importance of the opinion of

\footnotetext{
${ }^{84}$ Letitia Carson vs. Greenberry Smith, “Thayer Complaint,” 1855 Benton County Probate Court, http://www.orww.org/History/Letitia_Carson/Documentation/18541857 Carson_vs_Smith/18550802_Complaint Thayer-1.jpg.
} 
community members. ${ }^{85}$ Indeed, those same parties who were present "at the time when said Cattle were sold as alleged in said Complaint" would be "witnesses on the trial of said action.. ${ }^{\prime 66}$ Subpoenas were issued, many for the same men who had been called in the first case.

Shortly after the first complaint, Letitia amended her demand to $\$ 1200$ dollars, which reflected roughly the same amount at which the cattle had been appraised, according to Carson's estate documents. ${ }^{87}$ Smith responded to Letitia's complaint in short order, denying he had any reason to answer her claim and furthermore asserting that Letitia, in fact, owed the estate $\$ 500$. Indeed, he countered, that if the cattle were rightfully hers, she was in debt to the estate "for the securing and rearing of said cattle from 1845 to the time of said sale. ${ }^{" 88}$ Letitia summarily denied the counterclaim. Having now been located, David's nephew Andrew Carson and David Carson Jr. were called to testify on Smith's behalf. Additionally, Smith called two women to testify on his behalf, including Sarah Davis, wife of David and Letitia's closest neighbor David Davis, whom Smith identified as a material witness to his case. While her testimony is lost to history, it must not have made much of a difference in light of William Henry Walker's testimony, who had at this point been located. His deposition thankfully remains.

\footnotetext{
85 Ibid.

${ }^{86}$ Letitia Carson vs. Greenberry Smith, “Thayer Testimony,” 1855 Benton County Probate Court, http://www.orww.org/History/Letitia Carson/Documentation/18541857 Carson_vs_Smith/18550921_Testimony_Thayer-1.jpg

87 "Estate Appraisal," 1852 Benton County Probate Court, http://www.orww.org/History/Letitia Carson/Documentation/18521857 Oregon_Probate/18521207_Estate_Appraisal-1.jpg.

${ }^{88}$ Letitia Carson vs. Greenberry Smith, "Response Smith," 1855 Benton County Probate Court, http://www.orww.org/History/Letitia Carson/Documentation/18541857 Carson_vs_Smith/18551004_Response_Smith-1.jpg.
} 


\section{Walker Deposition}

One of the only testimonies that survived, Walker's deposition was incredibly

important to Letitia's success. The deposition is in question-and-answer format, including eight questions and Walker's succinct and direct responses. He attested that he has been acquainted with Letitia, David and Greenberry Smith since 1848 and had spoken with

David shortly before he died. He recalled the conversation as such:

In the last week of August 1852 David Carson \& Lutishia Carson were both sick, and I was stopping with them, taking care of them. When I first went there during said time David Carson asked me to get up the cattle, or cows for the purpose of milking. I drove into the corral seven calves and seven cows and two yoke of oxen. Out of the number which I had drove up which was about 40 head. While standing with me at the corral I remarked to David Carson that he had quite a large band of cattle. When he replied that those cattle there were not his except seven head ... and he further said that Twenty seven head of the cattle belonged to Lutishia Carson. He particularly pointed out an old pied cow that Lutishia Carson had bought said cow on the plains in 1845 and remarked that 27 head which he pointed out as Lutishia Carson's were the natural increase of said cow. ${ }^{89}$

Walker described the makeup of the herd and importantly, where he understood them to have been procured. "He told me she had bought that cow (which he pointed out) on the plains in 1845. That the balance were the offspring of said cow, all of which he said were the property of Lutishia Carson." "90 The testimony of Walker seemed to provide satisfactory evidence as to the rightful ownership of the cattle. Less than two weeks later, the jury found "a verdict for the plaintiff for twelve hundred dollars" and the additional court fees. ${ }^{91}$ Strikingly, unlike the previous case, Letitia won back the full amount to

\footnotetext{
${ }^{89}$ Letitia Carson vs. Greenberry Smith, "Walker Deposition,” 1856 Benton County Probate Court, http://www.orww.org/History/Letitia Carson/Documentation/18541857 Carson_vs_Smith/18561008_Deposition_Walker-2.jpg.

${ }^{90}$ Ibid.

${ }^{91}$ Letitia Carson vs. Greenberry Smith, "Judgment," 1856 Benton County Probate Court, http://www.orww.org/History/Letitia Carson/Documentation/18541857 Carson_vs Smith/18561020 Judgment \$1200.jpg.
} 
which she laid claim. The next year, the estate of David Carson, administered by Greenberry Smith, paid Letitia Carson "in full of all demands against estate." With that, Letitia Carson left the courtroom of Benton and indeed the entire county. Letitia Carson lived out the remainder of her days in Douglas County. 


\section{Chapter Two: Land and Labor in the West}

The twelve White men who heard the cases against Smith were no doubt influenced by the tumultuous political context of their day. To understand how they might have sided with a Black woman against an influential White community member, it is essential to examine how they were primed to hear the cases. While no written explanation exists of the individuals' specific reasons for deciding in Letitia's favor, it is possible to uncover what was important to the majority of early Oregonian settlers. Above all else was the entitlement of White men: to land, to labor, to self-determination. Letitia's case might have been tolerated because it posed no threat to those prerogatives. In fact, Letitia positioned her case in a way that appealed to the same themes, including the perils of land claims, the right to free labor, and the chance for self-sovereignty. The juries hearing the cases, if they were a representative sample, likely had experienced the fragility of property rights, supported free labor, and didn't question the morality of slavery but felt it had no place in Oregon.

Letitia's two court cases against Greenberry Smith and the estate of David Carson unfolded midway through the tumultuous 1850 s, a time of great upheaval across the nation. The court case cannot be separated from this unique historical context. Just over seven years after Letitia filed her Notice of Complaint, shots were fired at Fort Sumter, South Carolina, marking the beginning of the American Civil War. The buildup to what would be the bloodiest American conflict took decades to develop, snowballing in the late $1850 \mathrm{~s}$ and the first years of the $1860 \mathrm{~s}$. The debate over slavery and the increasing power of slave states in Congress extended to the far reaches of the frontier. Oregon settlers were not immune to these disputes; indeed, they flared up locally as well. As 
Gregory Nokes notes, "To say Oregon came close to becoming a slave state would be an exaggeration. But not a wild one. ${ }^{92}$ Nothing was decided. Prior to statehood, Oregon's status, like Letitia's, was unknown.

The two decades prior to the Civil War in Oregon were rife with change: they included the formation of a provisional government and the arrival of wagon trains. In the early 1840s, Americans in Oregon numbered in the low hundreds. By the end of the 1850 s, the population ballooned to over $12,000 .{ }^{93}$ The promise of free land enticed thousands of settlers to make the journey and soon Americans outnumbered any other colonial power in the region. Shortly after, Oregon gained territorial status but lost home rule. In addition to the struggle over the role that slavery would play in the future of the territory, Oregonians spent over a decade fighting to keep the land they claimed and their right to self-government. The political upheaval distracted from localized racial vigilance. Prior to statehood and the watershed of the Civil War, political and social life in Oregon was still taking shape. For a short time, overlapping priorities and power structures created opportunities for a Black woman that wouldn't exist even ten years later. Territorial law stated that no non-White person was "competent enough to testify" against a White party, yet Letitia's case was heard. ${ }^{94}$ Because the racialized social order was so engrained, there was little credible threat to its domination until emancipation, Reconstruction and the passage of the 13th, 14th and 15th amendments. During the

\footnotetext{
${ }^{92}$ R. Gregory Nokes, Breaking Chains: Slavery on Trial in the Oregon Territory (Corvallis, OR: Oregon State University Press, 2013), 32.

${ }^{93}$ US Census Bureau, "Resident Population and Apportionment of the U.S. House of Representatives," Census.gov, accessed August 21, 2021, https://www2.census.gov/library/visualizations/2000/dec/2000resident-population/oregon.pdf.

${ }^{94}$ Nokes, Breaking Chains, 96.
} 
antebellum period, White Oregonians had no reason to be concerned about a single Black woman. Their attention was elsewhere.

\section{Uncertainty and opportunity}

Letitia was likely held as a slave in Missouri, but like many enslaved people, little else is known of her early life. Formal manumission records for Letitia have not been discovered, but when she made the journey westward, it meant a chance to leave her enslaved status behind, crossing into terrain where slavery was not legally sanctioned. National consensus on the status of enslaved people in free territories had not been reached, but what is likely is that David and Letitia were very aware of the 1824 Missouri state statute that provided precedence for the doctrine of "once free, always free." ${ }^{.95}$ For the two decades prior to their departure, the Missouri legislature maintained that if an enslaved person was taken to a free territory, they could not be again enslaved. Whether that influenced their decision to emigrate cannot be known. Letitia left Missouri nearly ready to give birth and must have set forth hoping for the chance that she and her unborn child could be free. On the journey westward, Letitia's status certainly shifted. How much so remained to be seen. From the court records eight years later, we know that some Oregonians would not be willing to see beyond her once enslaved status, and indeed took an inverse perspective of the Missouri precedent. Greenberry Smith and others believed that "once a slave, always a slave."

As Letitia traveled West, so did questions about the extension of slavery. Thousands traveled the long trail the same year, heading to Oregon from Missouri and

${ }^{95}$ Secretary of State, Missouri. "Before Dred Scott History of Freedom Suits," accessed August 21, 2021, https://www.sos.mo.gov/archives/education/ahi/beforedredscott/history freedomsuits. 
many other states. Missouri had long been a hotbed of slavery debate, coming into national focus in 1820 when Congress attempted to quell the growing resentment between the North and South over the extension of slavery into new territories. The Missouri Compromise, as the separate agreements became known, allowed for Maine to be admitted as a free state and Missouri as a slave state in order to maintain Congressional balance. The status of any future territories would be decided by the latitudinal $36^{\circ} 30^{\prime}$ line; territories North of the line would enter as free states, and South of the line, slave. While the compromise marked a reprieve in the dispute, it proved shortlived. The annexation of Texas, a large slave-holding landmass, furthered sectional conflict. A border dispute with Mexico over Texas led to the Mexican American War in 1846. Though by no means ever fully extinguished, by the time the United States went to war with Mexico, the flame of slavery conflict fanned itself into a dangerous and imminent threat to the Union. War meant the possibility of adding additional territories and with each additional territory, the debate would rage anew.

Westward expansion caused significant strain on the country, threatening unity, and raising questions that weren't immediately answered. It was such a significant time in the restructuring of American history that historian Elliot West proposes it should be viewed as inseparable from the postbellum era. Instead of viewing them as distinct time periods, West maintains that the era of Westward expansion and the Civil War and Reconstruction eras in the South and East were really one longer period that he renames Greater Reconstruction. ${ }^{96} \mathrm{He}$ argues that the same questions plagued the nation during

\footnotetext{
${ }^{96}$ Elliott West, The Last Indian War: The Nez Perce Story (Cary: Oxford University Press, 2011), xxii, http://ebookcentral.proquest.com/lib/psu/detail.action?docID=431369.
} 
both previously demarcated eras; namely, how to keep a large nation together, the balance of federal power with state sovereignty and what do about citizenship of the region's non-White inhabitants. ${ }^{97}$ The era of Western expansion was equally critical, then, to the reshaping of the nation as was the Civil War era. Along with the land added from the annexation of Texas and the additional territories gained from the Mexican American War, American settler-colonists continued to travel further west, bringing with them the customs and beliefs of the regions they left, creating a contentious landscape and challenging previous stability. Oregon was no exception.

\section{Land as Enticement}

In 1845, when David and Letitia Carson arrived in the Willamette Valley, more than 3,000 others made the journey. ${ }^{98}$ Regardless of where their journey originated, emigrants largely came west seeking land. Like other emigrant trails at the time, the Oregon Trail was arduous, often deadly, and rife with risk. Conservative estimates put the total number of deaths on the trail between 15,000 and 30,000 , nearly ten percent of all who set out on the journey. ${ }^{99}$ Disease, gunshot wounds, accidents and drownings led to the Oregon Trail being known as "The Nation's Longest Graveyard." 100 The potential for reward had to be significant in order to pack up one's family and all worldly belongings

\footnotetext{
97 Ibid, xx-xxi.

${ }^{98}$ Suval, "The Nomadic Race," 320.

${ }^{99}$ William E. Hill, The Oregon Trail, Yesterday and Today: A Brief History and Pictorial Journey along the Wagon Tracks of Pioneers, Rev. ed (Caldwell, Idaho: Caxton Printers, 2000), xxxii; Andrea Mary Binder, "'Deep Is the Grave, and Silent:' Death and Mourning on the Oregon-California Trails" (M.A., United States -- Wyoming, University of Wyoming), 2, accessed September 10, 2021, http://www.proquest.com/docview/866190821/abstract/4E4483F838304452PQ/1; John Mack Faragher, "Midwestern Families in Motion: Women and Men on the Overland Trail to Oregon and California, 18431870." (Ph.D., United States -- Connecticut, Yale University, 1977), 16, accessed September 10, 2021, http://www.proquest.com/docview/302861507/citation/8FAB84C35C8D4B75PQ/1.

${ }^{100}$ William J. Bennett and John T. E. Cribb, The American Patriot's Almanac: Daily Readings on America (Thomas Nelson, 2013), 175.
} 
and make the trek. Land was the hoped-for reward, as well as the bountiful soil and temperate conditions that had been advertised for years already. ${ }^{101}$ When David and Letitia got to Oregon, they were able to claim 640 acres of land under the recently formed provisional government, a governmental body self-created in 1843, with dubious legitimacy. For years, vocal free land proponents in Oregon had been lobbying Congress to grant generous land tracts to settlers, without success. The provisional government didn't wait for federal legitimation, however, and passed the Organic Acts in 1843, granting a full square mile of land to any married white male settler. Claims to land, often the reason for emigration to the region, would prove fragile and therefore extremely precious to those who settled in Oregon.

Entitlement to land is a key function of settler colonialism, which functions in a distinctly different way than its more well-known cousin, exploitation colonialism. While classic colonialism is temporary, seeking to exploit the resources of a region and then retreat home, settler colonialism relies on physical bodies to replace original populations, a one-way system where settlers set forth from a home country with no intention of returning. ${ }^{102}$ Historian Gray Whaley describes the inherently oxymoronic justification of such a system. "Western sovereignty in the Americas rested on the doctrine of discovery, which conveniently trumped aboriginal occupation." ${ }^{103}$ Never free of people, or even free of sovereign nations, land ceded to the United States by force or sale continued to extend the nation's boundaries west. Yet, the question of what to do with that land was not

\footnotetext{
101 Suval, “The Nomadic Race,” 308.

${ }^{102}$ Katrine Barber, “'We Were at Our Journey’s End': Settler Sovereignty Formation in Oregon,” Oregon Historical Quarterly, 2019, 389.

${ }^{103}$ Gray H. Whaley, "Oregon, Illahee, and the Empire Republic: A Case Study of American Colonialism, 1843-1858,” Western Historical Quarterly 36, no. 2 (2005): 159, https://doi.org/10.2307/25443145.
} 
initially clear. Land gained from Britain at the end of the Revolutionary War was organized with the Northwest Ordinance of 1787 and formed the original American frontier. Land not yet admitted as states became the public domain, and the federal government created a revenue source by selling the land through private companies and speculators. ${ }^{104}$ As the United States grew, however, pressure mounted for Congress to distribute the land for free. Many resented land speculation and distrusted banks and creditors. However, one of the loudest chorus of demands came from those who insisted on free land as incentive or reward for settling in regions not yet populated with Americans. ${ }^{105}$ Many emigrants had already settled in regions outside of United States sovereignty, laying claim and setting precedent for American control before any formal treaty or sale. These "squatters" felt entitled to federally recognized lands in payment for their service.

\section{Land as Entitlement}

In Oregon, federal land donation proposals had been introduced in the late 1830s. In the decades prior to David and Letitia's arrival, the Oregon Country was sparsely populated by American settlers. New York capitalist John Jacob Astor had established his Pacific Fur Company at Fort Astoria at the mouth of the Columbia River in 1811, marking the beginning of permanent Euroamerican presence in the region. ${ }^{106} \mathrm{He}$ envisioned that the new American republic might "extend its dominion over a most interesting part of the opposite coast of the North American continent," with his help. ${ }^{107}$

\footnotetext{
${ }^{104}$ Chused, "The Oregon Donation Act," 49.

105 Ibid

${ }^{106}$ William G. Robbins, Oregon: This Storied Land, Second edition (Seattle: University of Washington Press, 2020), 16.

107 James P. Ronda, Astoria \& Empire (Lincoln: University of Nebraska Press, 1990), 243.
} 
Though his vision proved prescient, he was unable to keep a foothold for long. With the onset of the War of 1812 between the United States and Britain, the Pacific Fur Company outpost became endangered. Though far from the hostilities on the Atlantic front, Fort Astoria was cut off from supplies and important news, guarding against a perceived threat of a British naval attack. ${ }^{108}$ Feeling isolated and not optimistic about their future, the Americans at Fort Astoria sold the Pacific Fur Company to the British-owned North West Company in $1813 .{ }^{109}$ The War ended with the Treaty of Ghent the next year. Soon after, the North West Company merged with the British owned Hudson's Bay Company and all commercial efforts moved to Fort Vancouver. ${ }^{110}$ The British dominated regional commerce for the next two decades. The United States disputed British political claims to the region, however, and the Americans soon "came knocking at the Columbia." ${ }^{111}$ The Treaty of 1818, otherwise known as the Joint Occupation Treaty, was signed to avoid conflict so soon after the end of the War of 1812 . The treaty gave both nations tentative joint occupation rights to the region. Neither nation was granted sovereignty, and though settlement was allowed under the treaty, ownership of land was not. ${ }^{112}$ That didn't stop settlers from coming, and it didn't stop them from demanding land titles. By the time the wagon trains of 1845 hit Oregon soil, early settlers had been asking Congress for many years to grant them land that wasn't the nation's to give. ${ }^{113}$

\footnotetext{
108 Ibid, 277-288.

${ }^{109}$ Robbins, Oregon: This Storied Land, 17.

${ }^{110}$ Ronda, Astoria \& Empire, 335; Robbins, Oregon: This Storied Land, 32.

${ }^{111}$ Robbins, Oregon: This Storied Land, 305, 315.

112 Suval, "The Nomadic Race," 312.

${ }^{113}$ Kenneth R. Coleman, "'We'll All Start Even': White Egalitarianism and the Oregon Donation Land Claim Act," Oregon Historical Quarterly 120, no. 4 (2019): 417.
} 
In the latter part of the 1830s, American settlers started to arrive in the Oregon Country. Initially few in numbers, American settlers - mostly missionaries - lived fairly peacefully with their French Canadian and British counterparts prior to the 1830s. According to early Oregon historian Frederick Holman, "It was a peculiar, but pleasant, state of affairs, where men respected the rights of each other and there was no government." ${ }^{114}$ With no formal law of the land, Dr. John McLoughlin of the Hudson's Bay Company was widely considered de facto statesman, with his own claims on prime land in modern day Oregon City. ${ }^{115}$ Newly arrived American missionaries disputed those claims, asking for federal land grants to counter perceived outsized British influence. ${ }^{116}$ They wanted assurance from the federal government that the land they laid claim to and 'improved" ${ }^{117}$ would be protected. "We need a guarantee from the Government that the possession of the land we take up and the improvements we make upon it will be assured to us," Methodist missionary and settler Jason Lee wrote in a 1839 letter to Congressman Caleb Cushing. ${ }^{118}$ Senator Lewis Linn from Missouri beseeched Congress to entice more settlers by offering a whopping 640 acres of land to White male adults. ${ }^{119}$ Though it would take more than a decade before the federal government extended land grants to Oregonians, eventually Americans in Oregon took matters into their own hands.

\footnotetext{
${ }^{114}$ Frederick V. Holman, "A Brief History of the Oregon Provisional Government and What Caused Its Formation," The Quarterly of the Oregon Historical Society 13, no. 2 (1912): 89-139, https://www.jstor.org/stable/20609900.

${ }^{115}$ Ibid, 98.

${ }^{116}$ Suval, "The Nomadic Race," 314.

${ }^{117}$ Clearly, the colonizing view of what improvement of the land meant was inherently rooted in White supremacy. For more on the impact of settler colonialism and land hunger on native populations, see Katrine Barber, "We Were At Our Journey's End."

${ }^{118}$ A. Atwood, The Conquerors: Historical Sketches of the Settlement of the Oregon Country, Embracing Facts in the Life and Work of Rev. Jason Lee, The Pioneer and Founder of American Institutions on the Western Coast of North America (Glendale, Calif.: Arthur H. Clark Company, 1907), 66, quoted in Suval, "The Nomadic Race," 313.

${ }^{119}$ Coleman, "We'll All Start Even," 417.
} 
As evidenced from the thousands of emigrants who travelled the arduous Oregon Trail prior to territorial status, American settlers didn’t wait for formal agreements to move to new territories and claim them as emissaries of the United States. "Squatters," as they were known at the time, moved faster than the federal government, staking out prime real estate before any other pioneering spirit could take it first. ${ }^{120}$ For those small farmers tired of competing with increasingly powerful plantation owners in the South or those experiencing economic hardship in the Old Northwest, the promise of fertile soil at little or no cost was enticing. Squatters occupied land and then demanded the federal government legalize their claims. Initially, their claims proved problematic for politicians who weren't sure what to make of their demands for federal recognition. Eventually preemption laws allowed squatters a pathway to legal land claims; they could purchase the land they lived on for a good price. ${ }^{121}$

Squatters had been taking land since the 1780 s when states began ceding land to the government and the federal government made a habit of taking land from Native peoples and other countries. Federalists and Jeffersonians took an anti-squatter stance in the early days of the Republic, but as Jacksonian Democrats gained power in the 1820s and 1830 s, they used squatters' rights as a platform to broaden appeal and held squatters up symbolically as noble pioneers. ${ }^{122}$ They were useful to Jacksonians in justifying Indian removal and unified Democrats in the North and South, allowing them to rally behind something other than slavery. They were also key in outnumbering the British in

\footnotetext{
${ }^{120}$ Suval, "The Nomadic Race," 307-308.

${ }^{121}$ Ibid, 308.

${ }^{122}$ Ibid, 309.
} 
the Oregon Country and eventually convincing them that their time had come to give up joint occupation. $^{123}$

The United States and Britain engaged in a tug-of-war over power and control of the Oregon Territory for many years after the Treaty of Ghent, thereby turning the region into an overtly imperial space. As historian Robert Clayton explains, "the Pacific Northwest was not an inert plane over which a geopolitical drama unfolded. It was created through a concatenation of diplomatic arguments and competing national outlooks." 124 Though European and American settlers had been in contact with Native tribes in the region through exploration and trade, imperial interests eventually took precedence over in person contact. ${ }^{125}$ This shift became significant later in the justification of settler claims to the land. "Native land was appropriated from afar, and embodied geographies of interaction were pared down and abstracted away, to the point where territory actually became non-native, underlying Native claims to the soil were seen only dimly, if at all, and territory was emptied of prior significations and seen as an imperial shell awaiting colonial development." ${ }^{126}$ In the early decades of the nineteenth century, the British seemed to be dominating that development, but American proexpansionist boosters had not given up.

Though the native population still outnumbered the White settlers, the British had outnumbered Americans in Oregon since 1818. However, British Hudson's Bay Company employees and French Canadian Trappers saw the arrival of steadily increasing

\footnotetext{
${ }^{123}$ Ibid, 321.

${ }^{124}$ Daniel Clayton, "The Creation of Imperial Space in the Pacific Northwest," Journal of Historical Geography 26, no. 3 (2000): 345.

125 Ibid, 328.

126 Ibid, 345.
} 
numbers of Americans over the course of the 1830s. Though it would take until 1846 for the United States to "possess" the region, American "colonization was well underway by 1841."127 Jason Lee and other Methodist missionaries arrived in Oregon in 1834, with more missionaries making the trek over the next 10 years. Emigration picked up exponentially in the early 1840 s and the biggest inducement was land. What right they had to make land claims was not clear, however, they justified their squatting rights as beneficial to the nation and demanded that their claims be made legal. Given the stipulations of joint occupation, the United States wasn't at will to grant lands without notifying the British of their intentions. Their presence in the region seemed to echo an ever-building national sentiment that Oregon was an inevitable addition to the country. Squatters in Oregon began to see themselves as necessary to ensure Oregon went to the United States and not the British. Linn asked Congress for land grants to induce further emigration. "Without these encouragements," he argued, "there would be no emigration of our citizens, and England would be left to occupy the whole country, through the agency of her Hudson's Bay Company." 128

British control over the Oregon Country struck fear in the hearts of American expansionists, whose numbers continued to grow. To validate American settler claims, senators Linn and Thomas Benton asked Congress to establish a territorial government to protect Americans against Indian threats, validate land claims and end joint occupation. Though Linn's 1843 bill suggesting 640 acres of land for every White male settler passed the Senate, it faltered in the House for lack of support. ${ }^{129}$ However, many would-be

\footnotetext{
${ }^{127}$ Whaley, "Oregon, Illahee, and the Empire Republic," 2.

128 Congressional Globe, 27th Cong., 3rd Sess., app., 134, quoted in Suval, "The Nomadic Race," 318.

129 Suval, "The Nomadic Race," 318.
} 
settlers predicted it would eventually pass. The result was unprecedented migration of wagon trains to Oregon. In 1843 alone, nearly 1,000 settlers travelled the Oregon Trail to settle in the Oregon Country to take advantage of the land they felt was promised to them. ${ }^{130}$ "If you are going to Oregon by all means go this spring for if Linn's Bill pass next year every man and every man's neighbor will move in that direction," Missouri native Jesse Applegate wrote to his brother in $1843 .{ }^{131}$ Many others felt the same, arriving as Applegate did after a long five months on the trail.

Just prior to the Great Migration of 1843, those Oregon residents already in the region had grown frustrated with the lack of federal intervention and the growing threat of British control. After several years of failed attempts to self-organize a provisional government, in 1843, American, British and French-Canadian representatives met at Champoeg to vote on a provisional government. The motion passed, and on July 5, 1843, Oregonians entered into a tentative experiment in self-government. They quickly passed the Organic Acts, among them a land act that echoed back to Lewis Linn's prior Congressional petition: 640 acres for any White male - an entire square mile.

Oregonians bent on luring more settlers west knew that women must be among them. Inherent in the structure of settler colonialism is the need for a substantial population that reproduces itself, a need which necessitated women making the trek westward. More specifically, the need required White women to emigrate to the region, so as to establish dominion both by force and by numbers with the desired racial makeup. If the United States were to take Oregon Country by the validity occupancy, they needed

\footnotetext{
${ }^{130}$ Holman, "A Brief History," 118.

${ }^{131}$ Leta Lovelace Neiderheiser, Jesse Applegate: A Dialogue with Destiny (Mustang, Okla.: Tate Publishing \& Enterprises, 2010), 45, quoted in Suval, “The Nomadic Race,” 318.
} 
a self-perpetuating system, one that encouraged breeding. A London newspaper editorialized that "The

Hudson's Bay Company is a strong company, so strong that it consists of the stronger sex only. The American squatter takes his wife with him. The child follows." ${ }^{132}$ Support for the self-validating system came from the highest office of the United States. In his Inaugural Address, President Polk lauded the efforts of westward emigrants. "Our title to the country of Oregon is "clear and unquestionable," he asserted. "Already are our people preparing to perfect that title by occupying it with their wives and children."133 Land claims, sanctioned or not, were extremely important in early westward expansion. They were both the inducement to White Americans to come West and the proof offered by White Americans of their entitlement to the region.

The boosterism by Linn and others and allusions to potential British competition worked, and many Americans prepared to move west. Emigrants to Oregon from Iowa in 1843 set out with both a desire for individual land wealth and a sense of patriotism in viewing their presence as essential to establishing American title to the land. An emigrant group preparing for westward travel noted the reasons they had decided to set forth: "They believe the Oregon Territory to be far superior in many respects, to any other portion of the United States-they believe it to be superior in climate, in health, in water privileges, in timber, in convenience to market and in many other respects." ${ }^{\prime 134}$ They

\footnotetext{
${ }^{132}$ London Morning Chronicle, quoted in "England and the United States," Baltimore Sun, April 30, 1846, 1, https://www.newspapers.com/image/365244526/ (accessed August 21, 2021).

133 James K. Polk, Inaugural Address, March 4, 1845, http://avalon.law.yale.edu/19th_century/polk.asp (accessed December 13, 2020).

${ }^{134}$ The Iowa Standard (Iowa City), Vol. III, No. I7, March 30, 1843, quoted in "Emigration from Iowa to Oregon in 1843," The Quarterly of the Oregon Historical Society 15, no. 4 (1914): 293, http://www.jstor.org/stable/20609980.
} 
encouraged others to do the same, noting the duality of purpose: Both "to secure to themselves, a permanent and happy home," as well as "to (secure) their country, one of the fairest portions of her domain."

\section{Soil for Free or Free Soil}

By 1845 , emigration had steadily increased in tandem with public support for westward expansion. David and Letitia set out with thousands of others to stake out their claim in the far reaches of American frontier. Like most of their fellow travelers, they had no guarantees for what lay ahead. Though many lobbied for territorial status, whether Congress would pass federal protection measures was yet to be seen, and settlers still resented the presence of Great Britain. The provisional government's Organic Laws of 1843 guaranteed inhabitants due process of law and a right to a trial by jury, no cruel and unusual punishment, and no takings of property without compensation. ${ }^{136}$ Yet, what authority they possessed or mode of enforcement was unclear. However, unlike many white travelers, Letitia and David made the journey with additional unknowns. How Black emigrants would be received in Oregon was still uncertain. The provisional government had outlawed slavery in 1843 , yet the vast chasm existed between what was said and what was actually done. With no method to enforce the antislavery law, many slaveholding settlers shirked the law and brought those they enslaved with them to Oregon. Letitia may not have been brought to Oregon as David's slave, but was,

\footnotetext{
135 Ibid.

${ }^{136}$ James Rood Robertson, "The Genesis of Political Authority and of a Commonwealth Government in Oregon," The Quarterly of the Oregon Historical Society 1, no. 1 (1900): 36, http://www.jstor.org/stable/20609444.
} 
however, a Black woman. And though slavery had been outlawed in name in the Oregon Country, that was not indicative of prevailing support for racial equality.

Though far from ubiquitous, anti-slavery sentiment dominated early Oregon settlement. Yet, just one year after the provisional government outlawed slavery, the nascent government passed an exclusion law, barring all Black people from settling in Oregon, enslaved or not. The punishment for disobeying the law was severe lashing. Together, these two measures illustrate the widespread racist ideology of free soil, a position that would seek to establish a paradise for White non-slaveholders. It would influence policy throughout the next decade and a half and would even find itself baked into the Constitution of the state, some 15 years later. Free soil ideology grew out of the efforts to convince Congress to give land to squatters for no cost. It morphed quickly, however, to support keeping new territories free of slavery. ${ }^{137}$ Many emigrants struck out for Oregon to escape the slave power they were unable to compete with in their home states or to escape the racial discord they saw unfolding around them. Emigrants from Iowa to Oregon vowed to keep their own traveling groups White. They saw Oregon as the manifestation of Jacksonian egalitarianism, meant to level the playing field for White males. ${ }^{138}$ R.W. Morrison, an 1844 emigrant to Oregon described the situation as he saw it. Unless a man owned enslaved people, "he cannot compete with the man that does... I'm going to Oregon, where there'll be no slaves, and we'll all start even."'139

\footnotetext{
${ }_{137}$ Jonathan H. Earle, Jacksonian Antislavery and the Politics of Free Soil, 1824-1854 (Chapel Hill: The University of North Carolina Press, 2004), 14, http://ebookcentral.proquest.com/lib/psu/detail.action?docID=413263.

${ }^{138}$ Coleman, "We'll All Start Even," 3.

139 Oregon Pioneer Association, Transactions of the Twenty-Second Annual Reunion of the Oregon Pioneer Association (Portland: Geo. H. Himes and Company, 1894), 55, https://catalog.hathitrust.org/Record/008376302, (accessed August 21, 2021).
} 
Morrison's optimism would prove naive. Despite its provisional laws, enslaved people were indeed brought to Oregon anyway, most poignantly evidenced by the fact that the 1844 exclusion law gave slaveholders three years to free their slaves. ${ }^{140}$ And though Morrison's hopeful sentiment rang true to Jacksonian free soil sentiment of the time, racial restrictions on land claims meant that not everyone would start even. In fact, White male settlers were granted an institutionalized head start, a donation of land on which they could build wealth and power. ${ }^{141}$ Though there existed dissent among Oregonians to racial exclusions, most wanted nothing to do with slavery, and even less to do with the threat free Blacks might pose to their White privilege.

Peter Burnett, a prominent member of an 1844 emigration party became a member of the Oregon provisional government's seven-member Legislative Council and wrote at the time of his goal for the new territory: "The object is to keep clear of that most troublesome class of population. We are in a new world under the most favorable circumstances and we wish to avoid most of those evils which have so much afflicted the United States and other countries."142 Burnett summed up the attitude of many early Oregon settlers who wished to distance themselves from the national chaos surrounding slavery by keeping all Black people out of the territory. Burnett's comment hinted at an idealized White utopia, free from racial issues that were troubling the nation at large.

Black exclusion laws were not unique to Oregon. As emigrants journeyed the Oregon Trail, they brought their attitudes with them. Many emigrants arrived from Ohio,

\footnotetext{
${ }^{140}$ Elizabeth McLagan, A Peculiar Paradise: A History of Blacks in Oregon, 1788-1940, 1st ed. (Portland, Or.: Georgian Press, 1980), 185.

${ }^{141}$ Coleman, "We'll All Start Even," 415.

142 Nokes, Breaking Chains, 47.
} 
the Middle West and the Mississippi Valleys, where laws restricted voting rights, court testimony, and other rights of free African Americans, including the right to settle in the territories. ${ }^{143}$ Early settlers like Burnett, then, were intimately familiar with racial stratification, especially among free Blacks. State legislatures in the Old Northwest at the time of frontier advancement feared freed slaves and passed laws specifically to keep Blacks from settling in the area, hoping to influence them to instead "return" to Africa. ${ }^{144}$ Settlers from the Old Northwest brought these ideas with them. However, not all Oregonians felt the same. Support for the exclusion act of 1844 was strong - though not unanimous - but the lash law proved repugnant to enough Oregonians that the law was repealed shortly after it was passed. ${ }^{145}$ There existed a line of racial exclusion that the majority of Oregonians felt comfortable with, and a law that threatened physical lashings apparently exceeded it. Many, like Burnett, pushed the line and others pushed back. Where the line would eventually land would take the next 15 years to solidify. When David and Letitia set out for Oregon, that line was still forming, and their presence would test it.

Letitia was certainly not the only Black person in Oregon in 1845 , nor was she the only formerly enslaved person as the subsequent 1850 census would show. The census listed 56 Black people living in Oregon, proving the ineffectiveness of total Black exclusion. ${ }^{146}$ This very well may be a low-end figure, but regardless, the population of Black settlers in the region did not equal the outsized attention paid to them as a subject

\footnotetext{
${ }^{143}$ McLagan, Peculiar Paradise, 24.

${ }^{144}$ Eugene H Berwanger, "The Frontier against Slavery: Western Anti-Negro Prejudice and the Slavery Extension Controversy” (Urbana: University of Illinois Press, 1967), 3.

${ }^{145}$ McLagan, A Peculiar Paradise, 26.

146 Richard, "Unwelcome Settlers," 37.
} 
of debate. Much of the early support for exclusion laws revolved around White anxiety over race mixing. An integral part of settler colonialism is in producing a population, and in the settlement of the west (Oregon Country in particular) that meant a White population. This clearly meant a goal of erasure for the existing native population, but it would also mean overlooking the impact Black people had in the region before the 1840s. For as long as Whites existed in Oregon Country, there were Black people as well. In fact, Black men like Moses Harris directly impacted the settlement of the Oregon Country, saving early wagon trains and facilitating the U.S. claim to the region. Harris was a mountain man who came west for fur trapping and came to know the region through which the wagon trains eventually arrived. He acted as a guide and rescued several lost parties on their way to Oregon. ${ }^{147}$ Rachel Belden Brooks arrived in Oregon in 1843, enslaved by Daniel Delaney. She had two children, likely Delaney's offspring, and continued working for the family after the Civil War. Records of her life in Marion County, Oregon, include the lawsuit she filed after Delaney died against his estate on behalf of herself and their child. Like Letitia, Rachel won. ${ }^{148}$ Others arrived in the Oregon Trail era, though the overall population of Black Oregonians remained relatively low.

Though the journey to Oregon may have also been financially prohibitive to many free Blacks interested in making it, the exclusion laws doubtlessly impacted the low numbers of Black emigrants. George Washington Bush, a free Black man who set out in 1844 with his family to Oregon, illustrated the desire to avoid potential trouble when he

\footnotetext{
${ }^{147}$ Oregon Northwest Black Pioneers Organization, Perseverance: A History of African Americans in Oregon's Marion and Polk Counties (Salem, Or.: Oregon Northwest Black Pioneers, 2011), 29-30.

${ }^{148}$ Oregon Northwest Black Pioneers Organization, Perseverance, 36-37.
} 
told fellow Missouri emigrants along the overland trail that his plan was to "watch, when we go to Oregon, what usage was awarded to people of color, and if he could not have a free man's rights," he would seek them elsewhere. ${ }^{149}$ Hearing of the atmosphere in Oregon, Bush eventually decided to avoid the territory altogether, settling north of the Columbia River, in British territory where "a recently passed black exclusion law would be difficult to enforce in that area." ${ }^{150}$ Bush arrived in the Oregon territory one year prior to the Carsons, who, like Bush, couldn't be sure of the usage awarded to free Blacks. Though they finished the journey despite the Black exclusion laws, like Bush, they were certainly aware of them, and were likely not expecting a warm welcome.

\section{Letitia's Arrival in Oregon}

Letitia's journey west held uncertainty, her status unclear, a metaphor for the spread of slavery into the western territories at the time. When she arrived in the Oregon Country, the status of land claims was equally nebulous. Perhaps the lure of free land enticed David and Letitia west, perhaps they hoped to take advantage of the freedom that might be granted Letitia under the "Once Free, Always Free" precedent. They were able to take advantage of the provisional land donation in any case and settled on 640 acres in the Soap Creek Valley in what is currently Benton County, Oregon. The next year, however, the status of Oregon shifted and with it, the fragility of land claims became clear.

\footnotetext{
149 John Minto, "Reminiscences of Experiences on the Oregon Trail in 1844.--II," The Quarterly of the Oregon Historical Society 2, no. 3 (1901): 212.

${ }^{150}$ Quintard Taylor, In Search of the Racial Frontier: African Americans in the American West, 1528-1990, 1st ed. (New York: Norton, 1998), 82.
} 
Oregonians had been canvassing Congress for territorial status for many years. Polk was elected in 1844 and praised the settlers who were already claiming the Oregon Country that "unquestionably" belonged to the United States. The next year, the dominant expansion narrative took on a decidedly divine tone. An article written in December 1845 explained that "true title is by the right of our manifest destiny to overspread and to possess the whole of the continent which Providence has given us for the development of the great experiment of liberty and federative self government entrusted to us." ${ }^{151}$ The occupation of the Oregon Country was key to fulfilling a divine right, a responsibility to spread democracy to the far reaches of the continent. It worked; Americans eventually outnumbered the British. Joint occupation was finally dissolved in 1846 and the boundary with Great Britain was settled at the 49th parallel, securing a vast swath of land for the burgeoning American empire. ${ }^{152}$ Oregonians looked forward to the promise of territorial status and secure land claims. When they finally achieved that goal, however, it proved complicated.

Territorial status didn't come immediately. For two years after the boundary was settled, Oregonians lived in a state of uncertainty. Congress would need to formally grant territorial status, but Congress was distracted. ${ }^{153}$ National events dominated Congressional attention and so the Oregon Bill was put on the back burner. Texas had been annexed the previous year which brought intense scrutiny over expansion of slave power. The United States went to war with Mexico in 1846, increasing the likelihood that additional territories would soon be added. The debate over slavery in the new territories

\footnotetext{
${ }^{151}$ Suval, "The Nomadic Race," 321.

${ }^{152}$ Ibid.

${ }^{153}$ Ibid, 6 .
} 
dominated all. Jacksonian Democracy fractured, as Northern Democrats resented the single focus of Southern Democrats: the extension of slavery. For a short time, Democrats had tried to ignore the slavery issue altogether and focus instead on supporting westward expansion. Yet expansion unavoidably brought slavery onto center stage. Attempts were made to compromise - Oregon for the North in exchange for Texas for the South, but they failed. ${ }^{154}$

With war in Mexico flaring up, a Northern Democrat proposed a controversial resolution: "That, as an express and fundamental condition to the acquisition of any territory from the Republic of Mexico by the United States...neither slavery nor involuntary servitude shall ever exist in any part of said territory, except for crime, whereof the party shall first be duly convicted." ${ }^{\prime 155}$ Even though it didn't pass, the Wilmot Proviso, so named for its proponent, David Wilmot, caused immediate outrage among southern Democrats. Fracture lines formed earlier in the party had been patched with the binding support of westward expansion, but the slavery question proved too strong. The substantial faction that splintered off from the slavery focused southern Democrats formed the basis of the emergent Free Soil party.

The Free Soil Party would prove short-lived, but the ramifications of the split were great. Anti-slavery Democrats would eventually form an important part of the Republican Party that emerged in 1854 . The events of the 1840s deepened sectional divides that would eventually tumble into war. Yet the annexation of Texas and the War with Mexico, paired with the Wilmot Proviso delayed Oregon's formal entry into the

\footnotetext{
${ }^{154}$ Ibid.

${ }^{155}$ Wilmot Proviso, https://www.archives.gov/files/legislative/resources/education/wilmot-polk/wilmotproviso.pdf, (accessed August 21, 2021).
} 
United States, leaving residents in limbo for over two years. Many had heeded the booster's call and came west to seek free land. Like David and Letitia, thousands of settlers had already claimed 640 acres and wanted to ensure the validity of their claim. "Our situation is not a pleasant one, on account of the uncertainty of it," explained provisional Governor George Abernethy. "We may be, in less than six months, under the laws and government of the United States; and we may, on the other hand, exist in our present state several years." ${ }^{156}$ Land claims held particular importance for settlers who felt they were owed a debt of gratitude for their service to the United States. After all, Oregon had been won from the British by the fortitude of the westward emigrants. Provisional supreme court judge J. Quinn Thornton summed up the reasoning for the sense of entitlement to land claims. "Whatever may have been the strength of the American title resting upon discovery, exploration, cession, and contiguity, an actual possession of the country by an agricultural people was wanting to render that title clear and indisputable." ${ }^{157}$ Early settlers, including members of Letitia Carson's juries, felt intensely that they were owed for the service they completed.

Territorial status was eventually granted in 1848 with the Oregon Bill, settling two issues regarding the land. It would be free of slavery and all land claims given under the provisional government would be revoked. Ironically, with long-awaited territorial status came both the end of self-government and nullification of most laws passed under the provisional government, including the 640 -acre land allowance. That which brought the wagon trains had been taken from the grasp of those settlers who had recently secured

\footnotetext{
${ }^{156}$ Provisional and Territorial Documents, MSS 1226, Reel 77, Item 12189, OHS Research Library, quoted in Suval, "The Nomadic Race," 322.

${ }^{157}$ Ibid.
} 
their claim. It would not be the end of the conversation about 640 acres in Oregon, however.

\section{Oregon Donation Land Act}

Just two years after the Oregon Bill passed, Congress was busy with the Great Compromise, aimed at quelling the slavery question that had erupted during the expansionist 1840 s without tipping the balance to either the North or the South. During that same session, however, Congressional delegate Samuel Thurston of Oregon had another goal. He had been sent from the Oregon Territory to once again claim for settlers the property they felt they were due. Thurston was singly focused on passing a Donation Land Claim Act for his state. Echoing Linn's' earlier reasoning that land would serve as reward and enticement for the necessary occupation of Oregon, Thurston endeavored to convince Congress of the necessity to repay the efforts of the early settlers with official land donations. He introduced a bill that would allow for any White male already settled in Oregon to receive 320 acres of land and 320 acres more if he was married. Many in Congress, as well as President Polk, agreed that current settlers should be recompensed. They were less comfortable with granting the same generosity in perpetuity. ${ }^{158}$ Thurston proposed that future settlers would be granted half that. Regardless of when they arrived, however, the bill required settlers to cultivate the land for four years in order to receive their title. Debate in Congress revised the bill some, most importantly by adding a provision that any male had to be an American citizen, providing further exclusion of Blacks from the opportunity to own land in Oregon.

\footnotetext{
158 James M. Bergquist, "The Oregon Donation Act and the National Land Policy," Oregon Historical Quarterly 58, no. 1 (1957): 19, https://www.jstor.org/stable/20612302.
} 
The DLCA had major implications. For one, it worked. Emigration increased, peaking in 1852 when 10,000 people made the westward journey to Oregon. ${ }^{159}$ Additionally, it was the first federal land act to give property title to women. Though state and federal land acts were evolving over the early 19th-century to allow more progressive protection for widows, it was believed that married women were incapable of buying land from the federal government. ${ }^{160}$ Yet, Thurston, the booster of the DLCA, knew how important it would be to provide special land allowances for married women.

The feature of the bill securing one-half of the land to the wife, is deemed to be just. The law of "homestead exemption," is fast becoming the doctrine of the day. This provision is merely the same law in substance. Besides, emigrating to Oregon from the States, places the female beyond the reach of her kindred and former friends; and it is certainly no more than right to place some little means of protection in her own hands. But the object is to produce a population, and this provision is an encouragement of the women to peril the dangers and hardships of the journey. ${ }^{161}$

The exemption Thurston mentioned referred to the growing practice of excluding women's property from being seized to pay their husbands' debts. He recognized the momentum of relatively progressive gender-based land policy and took it a step further to underline the importance of bringing both men and women in hopes of occupying the Oregon Country for the United States' continued expansionist goals.

The DLCA also provided a racially exclusionary land grant system, setting up a government funded entitlement system that would privilege Whites in Oregon. Race and land were inexplicably tied for generations to come. Inherent in the donation act was the

\footnotetext{
159 John David Unruh, The Plains Across: The Overland Emigrants and the Trans-Mississippi West, 184060 (University of Illinois Press, 1993), 120.

${ }^{160}$ Chused, "The Oregon Donation Act," 53.

${ }^{161}$ Ibid, 65.
} 
desire to establish a regional bastion for Whites, to support the upward mobility of the 'hardy yeomanry' the country was indebted to. For free-soil advocates and many antislavery members of other parties, the desire to keep Oregon, and other newly added territories, White was intentional. The intense abhorrence of the growing slave power was rarely a moralistic one, and in Oregon it was no different. The assumption of White supremacy permeated anti-slavery politics in Oregon, as it did around the country. Free land for non-elite Whites had long been the rallying cry of supporters of squatters' rights. One Jacksonian Democrat, Theodore Sedgwick III, denounced slavery for its impact on labor. "The institution is in every way a blight and a curse [that has] plunged the laboring class into degradation, and made labor itself dishonorable." 162 For Sedgwick and others, slavery's blight was due not to its degradation of human beings, but to its negative impact on the white laboring class. Still others accepted that slavery existed and did not object to its continuance, though desired to keep it contained.

Not everyone agreed, however. Southern Democrats worked in Congress to prove the federal government had no right to ban slave owners from bringing their "property" into western territories. ${ }^{163}$ Pro-slavery sentiment existed in Oregon as well and as more emigrants arrived, the political makeup shifted with each new group of settlers; there existed a constant state of flux. Given the focus on securing land claims and the prohibition of slavery by the provisional government in 1843, pro-slavery agitation in Oregon took a back seat during the 1840s. It wasn't until territorial status was granted, land claims were somewhat solidified, and statehood seemed inevitable that political

\footnotetext{
${ }^{162}$ Earle, Jacksonian Antislavery, 5.

${ }^{163}$ McLagan, Peculiar Paradise, 37.
} 
parties formed, and the slavery debate took on new life in Oregon. Part of the reason debate raged so heartily in Oregon, however, was the introduction of the idea of popular sovereignty as a way to determine slavery's role in the territories.

The same Congress that passed the Oregon Donation Land Claim Act was responsible for passing the Compromise of 1850 , again attempting to settle the everpresent slavery extension issue. Land ceded to the United States at the end of the Mexican-American war created conflict over how it should enter the union and threatened the tenuous balance of power. The Compromise of 1850 allowed California to enter the Union as a free state and for the territorial inhabitants of New Mexico and Utah to decide for themselves. The idea of letting territorial voters settle the slavery question had been introduced in 1847 by Senator Lewis Cass while Oregon was still fighting for territorial recognition. ${ }^{164}$

Conflict among Democrats over the extension of slavery threatened the party's future. Cass's proposed doctrine of "popular sovereignty," letting territories decide for themselves whether they would outlaw or allow slavery, removed the question from Congress' hands and, according to Cass, provided "another tribute to the original principles of our Government, and furnish another guaranty[sic] for its permanence and prosperity." Rather than quelling conflict, the doctrine of popular sovereignty seemed to sow further seeds of discord during the 1850 s, paving the way for the Kansas-Nebraska Act of 1854 and the violence associated with the events known as Bleeding Kansas.

However, in Oregon, the idea of popular sovereignty held a specifically attractive meaning. In 1848 , residents had gained territorial status and given up the ability to self-

${ }^{164}$ Suval, “The Nomadic Race,” 323-324. 
govern. Leaders were federally appointed, instead of elected, and weren't held in high regard by the prominent Oregonians. ${ }^{165}$ The loss of autonomy dealt a major blow to the individualism that defined settlers' view of themselves. Territorial rule was likened to England's rule over the Thirteen Colonies. ${ }^{166}$ The idea of popular sovereignty, come to fruition in the Kansas-Nebraska Act and meant to extend only to the matter of territorial slavery, took on a different meaning to Oregonians who were eager to apply the doctrine to all matters of governance. ${ }^{167}$ By the time the Kansas-Nebraska Act was passed in 1854, extending popular sovereignty to Oregon, the doctrine was celebrated as a reclamation of previously held self-determination. In the territorial legislature resolutions were introduced supporting the act and asserting that "... we claim for ourselves what we freely concede to our brethren in the States, the right to decide for our- selves what we will adopt, and what we will not adopt, in the government of our local affairs." ${ }^{\prime 68}$ The spirit of popular sovereignty ran high in 1854 and 1855, and though meant to deny federal regulation of slavery, ironically provided the backdrop against which members of the juries heard Letitia's demand for self-determination.

In Oregon, the Democratic party had formed in 1852 and hoping to avoid the conflict that threatened the national party, inserted a gag rule on the topic of slavery. ${ }^{169}$ By far the majority party in Oregon, Democrats were far from unanimous in their thoughts towards slavery but were forced to keep silent in order to maintain a semblance of unity. Nationally, southern Democrats railed against popular sovereignty, using

\footnotetext{
${ }^{165}$ McLagan, Peculiar Paradise, 38.

${ }^{166}$ Robert W. Johannsen, "The Kansas-Nebraska Act and the Pacific Northwest Frontier," Pacific Historical Review 22, no. 2 (1953): 131, https://doi.org/10.2307/4492028.

${ }^{167}$ Ibid.

${ }^{168}$ Ibid, 134.

${ }^{169}$ McLagan, Peculiar Paradise, 39.
} 
Oregon's anti-slavery ban as evidence of the potential evil of leaving "squatters" sovereignty over the land. ${ }^{170}$ However, even an informal agreement to side-step the slavery issue couldn't stop anti-slavery factions from forming, critical of the silence Oregon Democrats maintained. ${ }^{171}$ Anti-slavery Democrats were ridiculed publicly, accused of Black Republicanism and called insulting names, the worst being "abolitionist." 172

Abolitionism existed in Oregon, as it did elsewhere in the United States, and like ideas about free soil and squatters' rights, travelled with settlers on their journey from East to West. However, abolitionists were vilified and abused, and dissent was countered with slander, often from the pages of leading newspapers of the day. The Oregon Statesman printed the following editorial in 1851 condemning the work of the abolitionists and underlining the distinctly racist viewpoint of the paper and many Democrats of the day:

Their assertions that Negroes are entitled to approach our polls, to sit in our courts, to places in our Legislature are not more rational than a demand upon them that they let all adult bulls vote at their polls, all capable goats enjoy a chance at their ermine, all asses (quadruped) the privilege of running for their General Assemblies all swine for their seats in Congress. ${ }^{173}$

Despite the widespread distaste for abolitionism, eventually anti-slavery powers won the day. When the state constitution was approved in 1857 , slavery was voted against by a wide margin: 7,727 against to 2,645 in favor. ${ }^{174}$ The split illustrates well the political

\footnotetext{
170 Suval, "The Nomadic Race," 324.

${ }^{171}$ McLagan, Peculiar Paradise, 40.

172 Ibid.

173 “The African Race," The Oregon Statesman, July 13, 1851.

174 The Oregon Statesman, December 22, 1857.
} 
environment in Oregon before statehood; by far, more residents opposed slavery, though it was far from universal.

\section{Conclusion}

By the time David Carson died, Oregon was well on its way to statehood, but little else had been decided. Opportunity existed for those on the margins because the foundation was still being poured. Before it hardened, it could be tested. With emancipation and enfranchisement a decade later, White patriarchal rule would be threatened, and therefore racialized lines would solidify, leaving little wiggle room for anyone who might challenge them. The overwhelming sentiment in antebellum Oregon was rooted in the belief of White supremacy, but because that belief was so wholly taken for granted, there was little risk in allowing a Black woman the chance to recoup the value of the property and earnings she had lost. Given that she was requesting payment for herself as an employee, she affixed her own cause to the plight of the majority of early Oregon settlers and their quest for free labor. Judging against her would have been akin to sanctioning slavery. According to her testimony, she had quite literally labored under the belief that she would be compensated for her work. To ignore that agreement would be tantamount to allowing slavery to exist legally, setting a dangerous future precedent for a territory on the verge of statehood.

While little moral objection existed to the institution of slavery, Oregonians were eager to create a White settler utopia. However, banning Blacks from the region, or any other race for that matter, was not their sole preoccupation. Early Oregonians, including those sitting on the juries of the cases brought by Letitia Carson were determined to build their wealth and secure future stability for their progeny by farming the land they viewed 
as their entitlement. The land claims that brought them to Oregon, however, proved shaky. Considering what emigrants had to leave behind to make the journey, land was likely the most valuable asset for most settlers. They saw their sacrifice as part of a noble bargain: settlement on behalf of national expansionist pursuits in exchange for compensation. Though they held up their part of the contract, they had spent years uncertain if they would be repaid.

Perhaps the members of the jury saw themselves reflected in Letitia's case. That she was Black would have been unquestionably noted by all of them. But she had made the journey West, just like they had. She had settled down to the difficult life of homesteading - same as them. And though she was protected for a short time, her land, too, had been taken from her. Yet, importantly, she was not asking for her land back. To do so might have been a bridge too far, asking too much from the settlers to see her as David's wife and heir. Plus, if she had chosen to sue Smith as a widow, she would have lost her ability to sue for compensation as a laborer. But they knew her land had been taken, along with her biggest asset: her cattle. Just like they had, she held up her end of the bargain, and the jury provided her payment. 


\section{Chapter Three: An Intersectional Strategy}

In March of 1854, Letitia filed suit against Greenberry Smith for "the damages which I have sustained in consequence of the non-performance of the following contract made and entered into by and between the said David Carson during his lifetime and myself." ${ }^{\prime 175}$ The contract was at the very crux of Letitia's argument, the foundation on which she built her case. According to her, the contract promised payment for her service, which she had honored but for which she had received no payment. She had held up her end of the bargain, and in return all she had worked for was taken from her. Quite simply, the estate of David Carson owed what David himself had promised to her. Importantly, the contract was between employee and employer. Missing from her argument is any mention of being David's wife. Years later, Letitia would file a Homestead Act claim as a 'widow,' suggesting that she indeed considered herself married to David Carson. Why not then, file suit against David's estate as his widow, or on behalf of her children, the rightful heirs to his estate? Her willingness to step into a historically White space which had been designed to exclude her and demand her right to self-determination demonstrates extreme courage. ${ }^{176}$ Therefore, it is overly simplified to assume that Letitia didn't have any choice. She made the choice to bring a suit against an influential White man, she might very well have asserted that she and David were married. Interracial marriage was indeed outlawed, but so was slavery in the territory,

${ }^{175}$ Letitia Carson vs. Greenberry Smith, "Carson Complaint," 1854 Benton County Probate Court, http://www.orww.org/History/Letitia_Carson/Documentation/1854-

1857 Carson_vs_Smith/18540227_Complaint_L_Carson-1.jpg.

${ }^{176}$ For more on the history and evolution of the American courtroom as a historically White space, see Amanda Carlin, "The Courtroom as White Space: Racial Performance as Noncredibility," UCLA Law Review, February 17, 2016, https://www.uclalawreview.org/courtroom-white-space-racial-performancenoncredibility/. 
indeed so was the presence of Black people; clearly, there existed a wide chasm between what was law and what was done. Banning Blacks - enslaved or free - from testifying in court was a national standard, yet precedent existed even there. As explained below, formerly enslaved Robin Holmes sued his former owner in nearby Polk County just prior to Letitia's case. Letitia's choice to forgo a widow's status in favor of that of an employee deserves a more nuanced look, not only because failing to do so robs her of her agency, but because the success of her strategy provides a valuable insight into the complexities of the racial and political landscape of antebellum Oregon.

Taken on its own, the fact that Letitia Carson filed suit against a wealthy White neighbor in Benton County Court in 1854 is remarkable given the overt institutionalized racism of the era. Yet, despite the standard operating procedure of barring non-White testimony in court, there was precedent of just that; in a neighboring county even. ${ }^{177}$ Three years prior to Letitia's case, another former slave from Missouri brought suit in Polk County against his former master. Robin Holmes travelled with his wife, Polly, and three small children to Oregon in 1844 with the family of Nathaniel Ford, the man who had purchased them as slaves. After assisting him for several years in getting his land settled, Ford freed Robin and his wife, according to a promise made by Ford when they left Missouri. However, even though he freed Robin and Polly, Ford kept three of their children as wards, which he later alleged was an arrangement to which Robin and Polly had agreed. ${ }^{178}$ Robin and Polly brought suit against Ford, filing a writ of habeas corpus. The case predated Letita's suit by less than a year and was the first legal case brought by

${ }^{177}$ Nokes, Breaking Chains, 1.

${ }^{178}$ Ibid, 74. 
any Black person in the Oregon Territory. The case lasted more than a year, held up in court for various reasons, until Judge George H. Williams was appointed the new Supreme Court justice and handed down a definitive judgement only a few days after arriving in the territory. ${ }^{179}$ He judged in favor of the Holmeses and ordered Ford to return the children to their parents. Even though the family had once belonged to Ford as slaves in Missouri, according to Judge Williams, "as soon as the laws of Oregon touched the parties, the relation of master and slave was dissolved." 180

Likely Letitia was aware of the outcome of the Holmes case and the legal precedent it established; her attorney most certainly was. Perhaps the case gave Letitia confidence to file suit against Smith, as Judge Williams addressed the murky issue of the status of the formerly enslaved in no uncertain terms. Whether or not the judgment in the Holmes case influenced Letitia's legal strategy, it clearly did not dissuade Smith from using Letitia's once-held enslaved status as the crux of his argument against her. Despite Williams' decree that the enslaved were no longer bound once they were residents of Oregon, Smith obviously felt he had reasonable chances of success by invoking her enslaved status. Taking the constantly shifting laws and regulations regarding Blacks in the territory and the debate surrounding slavery as evidence, Smith may have relied on the fact that in the Oregon territory, no precedent held for long. Indeed, the 1853-1854 territorial legislature formally denied African Americans (as well as Native Americans) the right to testify against Whites in court, after the Holmes verdict and just one month

\footnotetext{
${ }^{179}$ Ibid, 92.

${ }^{180}$ Ibid, 92.
} 
before Letitia filed suit. ${ }^{181}$ The law didn't take effect until 1855 , however, giving Letitia a small window of opportunity to make her case. ${ }^{182}$

Judge Williams presided over Letitia's case as well. While describing clearly his views on the dissolution of enslaved status in a free territory, Williams was no friend to the Black race. "l have not objections to local slavery. I do not reproach the slaveholders of the South for holding slaves. I consider them as high-minded, honorable, and humane a class of men as can be found in the world," he once said. ${ }^{183}$ By his view, he was simply following the law. He would later describe his reasoning in the case:

"Whether or not slave holders could carry their slaves into the territories and hold them there as property had become a burning question, and my predecessors in office, for reasons best known to themselves, had declined to hear the case... I so held, that without some positive legislative establishing slavery here it did not and could not exist in Oregon and I awarded the colored people their freedom...So far as I know this was the last effort made to hold slaves in Oregon by force of law. There were a great many pro-slavery men in the territory, and this decision, of course, was very distasteful to them." 184

Williams wrote the famous "Free State Letter," published in in the Oregon Statesmen five years after the Holmes case that he was not against slavery where it already existed in the U.S., but was against slavery in Oregon as it violated the ideals of free labor, would encourage the presence of unwanted, "idle," and lazy Blacks, and risked alienating the free states. ${ }^{185}$ His letter represented the common anti-slavery sentiment in Oregon at the time: meant to bolster opportunities for White men and to discourage the growth of an

\footnotetext{
${ }^{181}$ Nokes, Breaking Chains, 95.

182 Ibid.

183 Philip Thoennes and Jack Landau, “Constitutionalizing Racism: George H. Williams's Appeal for a White Utopia," Oregon Historical Quarterly 120, no. 4 (2019): 473.

${ }^{184}$ George H. Williams, "Political History of Oregon from 1853 to 1865," The Quarterly of the Oregon Historical Society 2, no. 1 (1901): 6.

${ }^{185}$ Philip Thoennes and Jack Landau, "Constitutionalizing Racism," 473.
} 
undesirable population. When voting for the state constitution five years later, it was clear that most Oregonians agreed with him. ${ }^{186}$ That his judgment in favor of the Holmes' and his racist sentiments were not mutually exclusive shows how a jury of like-minded White men may have been primed to look at Letitia's case. If the voting patterns of 1857 were any indication, most of them were anti-slavery, and even more of them were against a Black presence in Oregon. Letitia's strategy of using an employee's status harnessed the current of anti-slavery sentiment and accessed the free labor ideology bolstering antiBlack sentiment.

Yet, what Letitia didn't claim to be is as important as what she did claim to be. While Letitia and Smith would argue in court documents over her status as either a slave or as an uncompensated employee, no mention was made to a marital or intimate relationship to David, which is conspicuous in its absence. It may be tempting as modern historians to assume that Letitia would eschew claiming a widow's status in court given the prevailing sentiment against racial mixing. Laws against interracial marriage, in fact, rose steadily in the second half of the 19th century. ${ }^{187}$ But the reality prior to the Civil War was more complex. White men on the frontier had long been used to choosing wives as they saw fit; for decades White male settlers married outside of their race when they took Native American wives. As historian Katrine Barber writes, White men "married Native women to tap into local knowledge and labor and to create the kinship ties necessary in the Indigenous economy..." ${ }^{188}$ More women eventually arrived in the region,

\footnotetext{
186 Richard, "Unwelcome Settlers," 5.

${ }^{187}$ Peggy Pascoe, What Comes Naturally: Miscegenation Law and the Making of Race in America (New York, NY: Oxford University Press, 2009), 3.

188 Barber, "We Were at Our Journey's End," 33.
} 
Black women included, and White men like David Carson still had need for labor divided along gender lines, and for offspring to support the difficult realities of homesteading.

Though freedom to choose a spouse was not the only right afforded to White men. Certainly, there was an important distinction between interracial marriage and interracial sex. Indeed, White male sexual privilege proved more powerful than legislation, especially in the antebellum era. It would be another half century before even they would face widespread enforcement of legal restrictions in whom they could marry. ${ }^{189}$

Formal anti-miscegenation laws came during and after the Civil War; the word miscegenation was coined a decade after Letitia filed suit in court. ${ }^{190}$ Oregon didn't pass formal anti-miscegenation legislation until 1866, when recently freed Blacks threatened the racial utopia White Oregonians had worked hard to create. ${ }^{191}$ As has been argued by historians Peggy Pascoe and others, anti-miscegenation legislation actually created racial distinctions and beliefs about interracial marriage, rather than reflecting the already existing beliefs of the populace. ${ }^{192}$ That's not to say that interracial mixing was encouraged or accepted prior to the Civil War. Oregon's exclusion laws of the previous decade had passed, in large part, due to White anxiety over race mixing. ${ }^{193}$ As Peggy Pascoe argues, though, the obsession with interracial marriage from the century after the

\footnotetext{
189 Ibid, 11.

190 Ibid, 1.

${ }^{191}$ Deenesh Sohoni, "Unsuitable Suitors: Anti-Miscegenation Laws, Naturalization Laws, and the Construction of Asian Identities," Law \& Society Review 41, no. 3 (2007): 597.

192 Pascoe, What Comes Naturally 2, 5. Peter Bardaglio, "Shamefull Matches': The Regulation of Interracial Sex and Marriage in the South before 1900," in Sex, Love, Race, ed. Martha Hodes (New York: New York University Press, 1999), 112.

${ }^{193}$ McLagan, Peculiar Paradise, 25.
} 
Civil War through the 1960s centered on miscegenation as unnatural. ${ }^{194}$ Prior to the Civil War, however, interracial sexual and marital relationships were regulated and criminalized in large part to uphold slavery. Racial mixing in southern states was dangerous because it threatened the precarious racialization that underpinned and justified slavery. While Oregon voters continued to bar slavery in Oregon, racial stratification was necessary for different reasons.

Racial lines in Oregon were drawn to uphold White supremacy and advance property and labor rights of White men. As evidenced in the debates surrounding the Oregon Donation Land Claim Act in Congress, restricting Blacks from owning land was a given; they had already been excluded from residing there. ${ }^{195}$ But other races were equally undesirable for the risk they posed to the purity of Whiteness and the threat they posed to the land rights of White settlers. Outlining his opposition to removing racial restrictions from the DLCA, Thurston declared that "It would give land to every servant of the Hudson's Bay Company, including some hundreds of Canakers, or Sandwich Islanders, who are a race of men as black as your negroes of the South, and a race, too, that we do not desire to settle in Oregon." 196

Racialized land claim requirements and interracial marriage restrictions represent how White supremacy functioned, in Oregon and beyond, to give Whites structural and institutional opportunity for advancement. In practice, however, the living arrangements of interracial couples may have been tolerated as long as it didn't threaten the property

\footnotetext{
${ }^{194}$ Pascoe, What Comes Naturally, 2-4,19.

${ }^{195}$ Coleman, "We'll All Start Even," 425.

${ }^{196}$ Debate of the House of Representatives, 28 May 1850, in Congressional Globe, 30 May 1850: 1079, col.

2, "A Century of Lawmaking for a New Nation: U.S. Congressional Documents and Debates, 1774 -

1875," accessed August 23, 2021, https://memory.loc.gov/cgi-bin/ampage.
} 
rights of White men, defined broadly. When David Carson was alive, his choices and his property were protected by his Whiteness. When he died, his property had the potential of adding to another White man's wealth. Whereas Letitia's Blackness may have been overlooked while David was alive, in his death she posed a threat.

For the seven years David and Letitia cohabited in Oregon, they likely lived like a married couple in many ways, though the evidence we have can never be conclusive. We know that Letitia and her children lived with David in a house on a land claim given by the provisional government. They built a home, raised a daughter, and had a son. David may have gone south in the Gold Rush as other neighboring Oregon settlers did, including Greenberry Smith. ${ }^{197}$ According to Smith's own testimony, Letitia was sick for six months in 1851 and 1852 and was unable to care for herself or her family and David "waited upon" her. ${ }^{198}$ They were joined by neighboring land claims and operated much out of sight of the historical record.

During the same seven years, Black exclusion laws were passed, repealed, amended, and passed again. Slavery was debated in local newspapers as well as local government. The two witnessed the evolution from a dubious provisional government to legitimated territorial status. In short, they bore witness to much change. The status of the region was in flux. The lives of individuals might not garner much attention. Married or not, on a functional level, it didn't really matter. What mattered is if their neighbors accepted their presence and whatever explanation they gave for their relationship. For

\footnotetext{
${ }^{197}$ Smith, The Smith Chronicle, 89.

${ }^{198}$ Letitia Carson vs. Greenberry Smith, "Greenberry Smith Answer," 1854 Benton County Probate Court, http://www.orww.org/History/Letitia_Carson/Documentation/18541857_Carson_vs_Smith/18541010_Answer_GB_Smith-2.jpg.
} 
whether David considered her a slave, a free Black servant or his wife, their relationship and her presence were illegal. But laws only matter as much as they are enforced; if Letitia and David lived outside of the law, they did so with the blessing - however tacit of their community. And the approval of one's community was more important than any law.

In early 19th century America, marriage was strongly encouraged by the government, both federal and state. From the colonial period to the antebellum period, the United States tried to bolster and buoy civil marriage contracts. As Peggy Pascoe and Nancy Cott argue, while the country grew, new states sought to strengthen their futures by encouraging marriage for the way it reflected and reinforced the ideal relationship between citizen and state. ${ }^{199}$ Monogamous marriage, after all, was a microcosm of the compact between the governed and governing. Marriages that qualified as acceptable were White, Christian, and heterosexual. An upstanding husband represented the head of state, taking care of his wife financially and ensuring her safety and well-being. His role also intentionally relied on Christian images of Christ as the head of his church. ${ }^{200} \mathrm{His}$ wife, on the other hand, by consenting to the marriage, reflected the obedient citizenry, whose duties and obligations were service in exchange for protection. The integrality of monogamous marriage to the endurance of the Union underpinned prevailing political beliefs and structured the framework around which the republic was built. ${ }^{201}$ The States, especially new ones, had vested interest in supporting the institution for the functions it

\footnotetext{
${ }^{199}$ Pascoe, What Comes Naturally, 23.

${ }^{200}$ Cott, Public Vows, 11.

${ }^{201}$ Ibid, 10-23.
} 
performed; codifying property, systematizing inheritance, channeling sexuality, and constructing race.

Along with the desire to encourage marriage, the government also had the power to limit it for those who did not fit the ideal. In doing so, the government established which bonds could be considered legitimate; all others it prohibited, and they were therefore illicit. ${ }^{202}$ Though the federal government played a big role in shaping marriage law and creating national policy around marriage, it was occupied with distribution issues - like the Oregon Donation Land Claim Act - and national defense. And while settlers moved west and further away from the legislative center of the nation, the reach of the federal government was not often felt. It fell to the states to create and regulate civil issues like marriage, but even then, in frontier areas, what was acceptable was more often decided by one's community - the 'informal public. ${ }^{203}$

As Nancy Cott argues, "State law set a framework that guided and influenced local communities, but because of its proximity, the community's ability to approve or chastise its members came first." ${ }^{204}$ This was especially true in the West. For much of the early 19th century, the western frontier of the United States was sparsely populated.

Governmental supervision was scarce. In Oregon, the self-formed provisional government created its own constitution, laying out laws they had no way to enforce, and without any legal claim. Indeed, the status of the region changed with every wagon train that arrived. The calls for territorial status and land grants were in some ways a request for federally given legitimacy and the resources and ability to regulate itself. Even with

\footnotetext{
${ }^{202}$ Ibid, 4.

${ }^{203}$ Ibid, 28-29.

${ }^{204}$ Ibid, 29.
} 
territorial status, much of the population remained diffuse and law enforcement scattershot. Despite laws against slavery and Black exclusion, for instance, the 1850 census shows 56 Blacks and "mulattoes" in the territory and while most of those listed show occupations as servants, domestics, or laborers, the 1860 census even lists two counted as "slaves." 205 In less densely populated regions, any laws were difficult to enforce; marriage laws were no exception. Thus, it fell to community members to be the enforcers of acceptable marriage and they were highly effective. Depending on the community, they could be liberal and open-minded with their approval, or they could be strict and unforgiving. A couple's fate, far from any other legal pathway to marriage, may very well have laid in the hands of their neighbors.

Additionally, marriage licenses were difficult to obtain and so could not be the only path to legally recognized marriage. ${ }^{206}$ In the early 19 th century, self-marriage, or common law marriage, was a typical avenue to marriage. In a settler colonial society, the necessity of reproduction was paramount and thus, legally recognized marriage was often secondary to childbearing. ${ }^{207}$ For White heterosexual couples on the frontier, if two people lived as a married couple with the approval of their community, they were considered legally married. In fact, as marriage became ever more encouraged by the state, the legal presumption of marriage became standard practice. In the court of law, a couple was presumed married unless proven otherwise. ${ }^{208}$

\footnotetext{
${ }^{205}$ Richard, "Unwelcome Settlers," 39.

${ }^{206}$ Cott, Public Vows, 28, 31.

207 Ibid, 31.

${ }^{208}$ Ibid, 39.
} 
Of course, David and Letitia were not a White couple; they were an interracial couple with an immense power differential. Not only was David significantly older than Letitia, David had likely owned or leased Letitia in Missouri. Whether or not their relationship was loving, committed, and mutually affectionate, it was also inherently unequal. David was 45 when he and Letitia set out for Oregon; she was not yet 30. No amount of genuine fondness could have outweighed the imbalance of power and position. White slaveholding men had long enjoyed unchecked sexual freedom over the females they enslaved, and the passage of anti-miscegenation legislation did little to curb their behavior. ${ }^{209}$ Despite laws banning interracial sex in the Southern slave states, it remained unenforced and overtly tolerated. In fact, the sexual exploitation of enslaved women often meant an increase in the wealth of a slave owner. If children were the product of such liaisons, and they often were, those mixed-race children inherited their enslaved status from their mother, in turn increasing the labor force of their father. ${ }^{210}$ Offspring of a sexual encounter between a slave owner and the woman he enslaved in essence reinforced established racial stratification. The same could not be said for the offspring of a White woman and a Black man, enslaved or free. If the enslaved status of the child followed its mother, then free 'mulatto' children would threaten the clear White supremacist distinctions necessary to justify slavery. ${ }^{211}$

While the vast majority of slave/master sexual encounters were forced, even socalled 'consensual' liaisons between Black Women and White men should be reframed and questioned, given the coercion inherent in them due to the limited choices of

\footnotetext{
${ }^{209}$ Bardaglio, "Shamefull Matches," 116.

${ }^{210}$ Ibid.

${ }^{211}$ Ibid.
} 
enslaved Black women and the disparity in society and under the law. ${ }^{212}$ There was little possibility of refusal, for fear of repercussions. There was no guaranteed redress for enslaved women against forced sexual intercourse - especially legally. In fact, as Sharon Block succinctly puts it: "No historian has recorded a conviction of a White man for the rape of a slave at any point from 1700 to the Civil War, let alone a conviction of a master for raping his own slave." 213 The prevailing theory supporting slavery was that masters would care for their enslaved in return for their obedience and servitude. In practice, the bodies of the enslaved were counted as property and therefore could be treated as desired.

The idealized relationship of mutual obligation between slave and master was based on the same nineteenth century ethos enshrined in the covenant between man and wife, citizen and state. The paternalistic theory held that it was a master's duty to clothe and feed, provide shelter and medication for his enslaved work force. Like a father, a king, a head of state, indeed Christ himself, the idealized slave master was held up as a firm but caring, benevolent leader. His subjects, in turn, were required to submit totally, in exchange for such protection and care. Total obedience and loyalty were demanded; total subordination taken for granted. Such ideals were fantastical; unimaginable cruelty and savagery was extended to the bodies, minds and souls of generations of slaves. No amount of socially encouraged 'noblesse oblige' could make up for holding humans as property. The inhumanity of slavery was debated by abolitionists, of course, but they were few. It was less common for anti-slavery advocates to argue against it based on

\footnotetext{
212 Bardaglio, "Shamefull Matches," 117. Also Sharon Block, "Lines of Color, Sex, and Service: Comparative Sexual Coercion in Early America," in Sex, Love, Race, ed. Martha Hodes (New York: New York University Press, 1999), 143-148.

${ }^{213}$ Ibid, 143.
} 
moral grounds. ${ }^{214}$ Even among its critics in the North and West, the belief in the inferiority of Black people was assumed. And Black enslaved women bore the brunt of the unchecked sexual proclivities of their masters.

While no evidence has yet been discovered that proves David Carson was Letitia's master, it seems most likely that he was. Beyond Greenberry Smith's testimony that David and Letitia were master and slave, there is evidence that David Carson had leased an enslaved woman prior to his departure from Missouri. The evidence exists precisely because David was involved in a court case that alleged his own mistreatment of a young, enslaved girl. Indeed, in 1844, a year before leaving Missouri with Letitia, David was the plaintiff in a court case that involved a young, enslaved girl he had 'hired' from her owner. According to the court records, in 1843 David "hired the negro girl" from her owner Susannah White, 'at the price of 45 dollars' for one year. However, in January of the following year, Ann Eliza, aged "13 or 14 years old," ran away from her post to the home of the Whites. When David sent for the young girl, Susannah White's son "refused to permit said negro to return to the service of (David), giving as a reason that she had been badly treated by (David), and showed...a scar on the face of said negro girl about two inches long which (White's son) stated had been inflicted by (David), and which had the appearance of having been inflicted by a stone or club." The Whites introduced Ann Eliza in court, offering to prove that while in his service, she "was treated

\footnotetext{
${ }^{214}$ Abolitionists were certainly present in Oregon, though often mocked and vilified. See Jim M. Labbe, "The Colored Brother's Few Defenders: Oregon Abolitionists and Their Followers," Oregon Historical Quarterly 120, no. 4 (2019). Only 13 percent of the anti-slavery vote in Oregon, for example, voted against along abolitionist lines. Labbe, "The Colored Brother's," 452.
} 
with inhumanity and cruelty," and that David had "debauched" her. 215 "Debauched" is used in the 19th century as a courtroom acceptable euphemism for child rape.

The aptly named Whites refused to honor their contract with David because he "treated the negro girl inhumanly (sic) or in a manner that endangered her health." The court documents provide a near perfect summation of the expected relationship between slave and master, as well as the reality of the type of latitude White men actually enjoyed. Submitted to the court is the contract David signed in hiring Ann Eliza: "I Susannah White have this day hired to David Carson my negro girl Ann Eliza for twelve months and said Carson does hereby bind himself to furnish said girl with good and sufficient clothing suited to the season...Said Carson hereby binds himself to treat said girl humanly

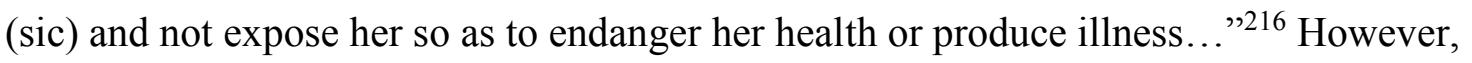
David objected to the testimony of the Whites and Ann Eliza and the court upheld his objection. The jury never heard the evidence, and the case was dismissed. Six months later, Letitia was pregnant with his child.

David appeared in court as the plaintiff, suing the Whites for refusing to release Ann Eliza to him in fulfilment of their contract. Whether or not the allegations made by the Whites were true, David felt confident enough in his position to file suit against them, likely knowing what they would allege. His confidence was rightly placed. As a White man, it was unlikely he would meet any serious consequences for any of his actions toward a young, enslaved girl, even one who belonged to someone else.

${ }^{215}$ Carson vs White, April 1844 Platte County Circuit Court. ${ }^{216}$ Ibid. 
The allegations against David do not provide unequivocal proof that he physically and sexually assaulted Ann Eliza, but the evidence against him was apparently serious enough that the White family chose to break a contract over it, triggering litigation. It also doesn't necessarily provide proof of how he treated Letitia, or the nature of their relationship, but it shows that he had experience using slave labor and raises serious questions regarding his treatment of enslaved people. Other accounts exist by enslaved women of sexual abuse by slave masters, and it is clear that sexual exploitation was rarely isolated behavior; indeed, it was often pathological. ${ }^{217}$ Within a year of the court case, David left Missouri with Letitia, an enslaved woman pregnant with his child. At the very least the Missouri court case should give pause and consideration to the choices Letitia had; in becoming pregnant - even in leaving Missouri.

Yet, David and Letitia did leave Missouri and a few weeks into the journey, she gave birth to their daughter, Martha. They made the journey with many other emigrants from Missouri, some of whom became their nearest neighbors. As the approval of the community was key to a successful and peaceful existence on the frontier, these fellow emigrants would become integral to the acceptance of whatever relationship David proffered. Greenberry Smith himself was a member of the emigration train. Letitia's presence on the journey is not mentioned in any account of the trip. As one of the only Black people on the journey, she is mentioned in the emigration census as a "negro woman” with David Carson's wagon train. ${ }^{218}$ Martha's birth was recorded five years later

\footnotetext{
217 "On Slaveholders' Sexual Abuse of Slaves Selections from 19th- \& 20th-century Slave Narratives," The Making of African American Identity: Vol. I, 1500-1865, Primary Resources in U.S. History and Literature, Toolbox Library, National Humanities Center, accessed August 23, 2021, http://nationalhumanitiescenter.org/pds/maai/index.htm.

${ }^{218}$ Travel journals referenced include those noted in Donna Wojcik Montgomery, The Brazen Overlanders of 1845, Rev. ed. (Bowie, Md: Heritage Books, 1992), Sarah J. Cummins, Autobiography and
} 
in the 1850 census as "in the Rocky Mountains." ${ }^{219}$ No doubt the birth was terrifying for Letitia, for as historian Robert W. Carter points out, "Child birth was a risky undertaking for American and European women in the nineteenth century, and the trail only augmented the problems." ${ }^{220}$ The birth must have been a remarkable event for those that traveled with Letitia, but the event doesn't make any of the travel journals or written reminiscences of fellow overlanders. David Carson does, however.

In an account given to the Oregon Pioneer Association in 1877, Stephen Staats, a fellow 1845 emigrant, gave an account of a harrowing experience while crossing near Mt. Hood that cast David Carson as a heroic figure. The group Staats and Carson were travelling with were caught in a blinding snowstorm and the company was separated from their cattle. David, determined not to lose a favorite cow, managed to save one of his own during the storm. The group made camp for the evening, but the next morning "Uncle Davy," as he is referred to in the account, set out in search of the lost cattle. Staats describes David as "an old mountaineer," with "more than ordinary courage and endurance."

Now as to the other lost cattle, early in the morning after the storm, Uncle Davy Carson, with a few trusty and dauntless spirits took the back trail in search of them, and after a toilsome and tedious ascent, found them huddled together, high up between two ridges running down from old Mt. Hood, with his covering of perpetual snow; and so completely bewildered, that it was almost impossible to start them from their sheltered nook; but Uncle Davy with true grit and unabated energy determined that to camp they must go; and go they did, but not until Uncle Davy became so wearied with excessive exertion that he must resort to some means to refresh himself, so after casting about for a time, a bright idea struck

Reminiscences of Sarah J. Cummins ... (La Grande, Or.: La Grande printing co., 1914), https://catalog.hathitrust.org/Record/008913258. "Diary of an Emigrant of 1845," The Washington Historical Quarterly 1, no. 3 (1907): 138-58, http://www.jstor.org/stable/40473807.

219 " 1850 Federal Census of Benton County OR," accessed August 21, 2021, http://genealogytrails.com/ore/benton/census/1850/18501.html.

${ }^{220}$ Robert W. Carter, "'Sometimes When I Hear the Winds Sigh': Mortality on the Overland Trail," California History (San Francisco) 74, no. 2 (1995): 153. 
him, (though he was always in the habit of being similarly stricken), espied a bell suspended from the neck of a poverty stricken cow, and immediately made for it; it was soon stripped from the cow and in a few minutes the lacteal fluid from the gentle beast had filled it to the brim, and soon Uncle Davy was himself again. The refreshing beverage restored him to new life and animation, and he shortly came shouting into camp with not a hoof missing. ${ }^{221}$

Staats' tale of David's heroism, told over 30 years later, might have been embellished or dramatized; they certainly fit into the romanticized tales of brave and hardy pioneers popularized in the late 19th century. Regardless, it is certainly indicative of the way in which David's fellow travelers viewed him. Coming to Oregon with Letitia, he had the admiration as an avuncular, but well-respected community member. Indeed, Staats ended his account with the following description of Carson: "But Uncle Davy is gone, peace to his ashes; a kind thought to his memory, and may some abler pen than mine, at some future time recount the nobleness of his actions in all his intercourse with his fellow man." 222 Clearly, David was a revered and respected member of the 1845 overland travelers. If many of those fellow travelers eventually became David and Letitia's neighbors, it's safe to assume that David could have counted on the benefit of their shared experience and regard. It may very well have extended to their tacit approval of whatever relationship they perceived between David and his Black female companion.

David and Letitia may have been able to count on the forbearance of their White neighbors due to David's trail reputation; they had something else on their side as well. While some unique communities in antebellum America might have had a certain level of patience for interracial relationships in their midst, it would be much more likely for

\footnotetext{
${ }^{221}$ Oregon Pioneer Association, Transactions of the Fifth Annual Reunion of the Oregon Pioneer Association (Salem: E.M. Waite, Steam Printer and Bookbinder, 1878), 52.

222 Ibid.
} 
couples that looked like David and Letitia. American anti-miscegenation legislation had always intended to bolster slavery, but it had a secondary goal: to preserve the purity of White womanhood. ${ }^{223}$ White men had less restrictions over their behavior and their sexual freedom was tolerated if not encouraged. The long precedent of White men marrying Indian women showed that even interracial marriages were sometimes accepted, as long as the man was White and the lawmakers far away. ${ }^{224}$ The dominion of White slave owners over the bodies of their enslaved was taken for granted. And even though anti-miscegenation laws technically applied to both men and women, even nonslaveholding White men were far less likely to be prosecuted for breaking that law than White women or Black men in the first half of the 19th century. ${ }^{225}$

The real obsession over interracial mixing came with the fear of White women having sexual relationships with Black men. The hysteria surrounding this type of miscegenation would culminate in the brutal and decades-long terrorism of lynching in the Jim Crow south after the Civil War. The accusation of rape of a White woman by a Black man was often enough for a White mob to seek out and publicly murder the accused. Accusations were flimsy or outright fabricated, but the threat to White womanhood was a rallying cry strong enough to muster the vigilantes to action.

David and Letitia were protected in some regards by his Whiteness and his maleness. Whether they lived together as husband and wife or not, her mere presence in Oregon threatened the White utopia early settlers planned for the region. In the hierarchy of discretionary enforcement, the will of a White man in the mid-19th century wasn't

\footnotetext{
${ }^{223}$ Bardaglio, "Shamefull Matches," 113.

${ }^{224}$ Pascoe, What Comes Naturally, 11.

${ }^{225}$ Ibid, 11.
} 
likely to be questioned as long as he lived within the accepted norms of his immediate community. As a Black woman, Letitia did little to threaten the sanctity of White womanhood. Their relationship might have been accepted by their neighbors as marital, it might have been ignored or overlooked, or it might have been assumed by their neighbors to resemble a servant and master relationship, including the tacit acknowledgement of a sexual relationship. None of these relationships would have been without precedence, though interracial marriage surely would have been the least commonly recorded. More interracial mixing surely happened than made it to the written record, however. Especially when communities were less likely to accept an interracial marriage, a couple might live in hiding or keep a relationship secret. Liaisons between White women and Black men show up in court rooms, especially when inheritance, estate or wills were contested. As historian Martha Hodes notes, "Testimony in all such cases often made it clear that White neighbors had known about a liaison before." ${ }^{226}$ If no court case surrounded an interracial relationship, that liaison might be lost to history. For if a mixedrace couple found a liberally minded community, they may well have lived in a tenuous peace if they maintained acceptable racial decorum and didn't demand too much. "The law was usually inclined to step in only when interracial couples began to claim the public respectability and the property and inheritance rights that went into marriage," writes Peggy Pascoe. ${ }^{227}$ Prior to David's death, he and Letitia may have been shielded by the relative freedom awarded to a White man to live as he chose, a tolerant community and the fact that they did not demand a stake in the public sphere.

\footnotetext{
${ }^{226}$ Martha Hodes, White Women, Black Men: Illicit Sex in the Nineteenth-Century South (New Haven: Yale University Press, 1999), 3.

${ }^{227}$ Pascoe, What Comes Naturally, 12.
} 
Letitia may also have been protected by her isolation. When she came across the plains, she was among the first African American women to enter Oregon, and there weren't many who preceded her. As the census of 1850 and 1860 show, the exclusion laws passed by the provisional and then territorial government were effective in preventing Black emigration. Not to mention that at the time, a majority of Black people in the United States were enslaved and not able to choose where they lived. And though some enslaved people were brought to Oregon, the anti-slavery sentiment discouraged many who might have otherwise come. Letitia may have been accepted in the otherwise hostile region because she was singular, isolated, an aberration. Like other isolated Black women in the early western frontier, Letitia may not have been openly welcomed, but presented no immediate threat because she existed outside a larger Black community. "Token" Blacks, brought from slavery to the region were tolerated, as long as they remained in acceptable roles of deference and service, a single Black woman may not have raised alarm bells.

While Letitia may very well have seen herself as David's wife, there are very good reasons why she would choose not to which have nothing to do with her race. The 19th century United States was unapologetically propped up by multiple systems of supremacy, not only by race but by gender. Married women were especially subject to inferior financial and legal status, given the prevalence of coverture laws throughout the United States. Brought to the colonial United States from English common law, coverture ensured that once married, a woman's financial, legal, civic - in essence her entire public existence - was subsumed into that of her husband's. Women weren't allowed to file suit, 
engage in legal contracts or own property. 228 "Upon marriage," historian Nancy Cott writes, “a woman's assets became her husband's property and so did her labor and future earnings. ${ }^{.229}$ While states began to amend or abolish coverture laws in the mid to late 1800 s, Oregon didn't pass its first married women's property law until $1878 .{ }^{230}$ When contemplating her legal strategy, Letitia may very well have considered that as David's wife, all of the property she brought to the relationship would have been absorbed by him, and thus become part of his estate upon his death. And a significant part of Letitia's case against Greenberry Smith centered on individuating her own assets from his.

Less than a month after her initial complaint against Smith, Letitia's attorney Andrew Thayer stated in a deposition that he had written proof that the cattle taken by Smith as a part of Carson's estate in actuality belonged to Letitia and were therefore taken in error. According to the deposition, Thayer named Henry W Knighton as a material witness and that Thayer himself "has in his possession two letters purporting to have been written by the said Knighton, wherein (Knighton) states that sometime...during AD 1845, he...sold a cow to David Carson." According to Thayer, the letter written by Knighton also stated that "David informed him that (he) was purchasing said cow for plff (sic) with her money." Additionally, Thayer stated in the deposition that a man named William Henry Walker could attest to the fact that the cow owned by Letitia then produced 29 more cows. ${ }^{231} \mathrm{He}$ was unable to be located, though, and so no such proof

\footnotetext{
${ }^{228}$ Cott, Public Vows, 11.

229 Ibid, 12.

${ }^{230}$ Hazem Alshaikhmubarak, R. Richard Geddes, and Shoshana A. Grossbard, "Single Motherhood and the Abolition of Coverture in the United States," Journal of Empirical Legal Studies 16, no. 1 (March 2019): 95, https://doi.org/10.1111/jels.12210. "State of Oregon: Woman Suffrage - Hierarchy and Coverture." Accessed March 20, 2021. https://sos.oregon.gov/archives/exhibits/suffrage/Pages/context/hierarchy.aspx. ${ }^{231}$ Letitia Carson vs. Greenberry Smith, “Carson Statement,” 1854 Benton County Probate Court,
} 
was provided. Though awarded financial compensation by the jury in her initial suit, it did not include specific remuneration for the cattle. She did not give up.

In the second suit, Letitia specifically demanded that the price of the cattle sold by the Carson estate be paid back. Luckily, Walker was located and was able to provide proof corroboration for her claims. ${ }^{232}$ His testimony was crucial to her case. Walker was deposed in August of 1852 and claimed that while stopping to take care of Letitia and David Carson, who were both sick at the time, he "remarked to David Carson that he had quite a large band of cattle where he replied that the cattle there were not his." ${ }^{233}$ As Letitia had claimed in the previous proceedings, "he further said that 27 head of the cattle...belong to Lutishia (sic) Carson." ${ }^{234}$ Most importantly, Walker provided backup of the claim that one of the cows was responsible for the rest of the other 27 head of cattle. "He particularly pointed out an old pied cow and said that Lutishia (sic) Carson had bought said cow on the plains In 1845 and remarked that 27 which he had pointed out as Lutishia Carson's were the natural increase of said cow."235 Walker provided the court with David Carson's views on the matter. When asked what David had specifically told him about where Letitia had gotten the cow, Walker was again direct. "He told me she had bought that cow (that he pointed out) on the plains in 1845. That the ballance (sic) were the offspring of said cow all of which he said were the property of Lutishia (sic)

http://www.orww.org/History/Letitia_Carson/Documentation/18541857 Carson_vs_Smith/18540313_Statement_L_Carson-1.jpg.

${ }^{232}$ Bob Zybach, "Strangely Absent from History: Carson vs. Smith, 1852-1857," Oregon State Bar Bulletin 77, No. 1 (October 2016): 24-28.

${ }^{233}$ Letitia Carson vs. Greenberry Smith, "Walker Deposition," 1856 Benton County Probate Court, http://www.orww.org/History/Letitia_Carson/Documentation/1854-

1857 Carson_vs Smith/18561008 Deposition_Walker-1.jpg.

${ }^{234} \mathrm{Ibid}$.

${ }^{235}$ Ibid. 
Carson." ${ }^{236}$ The deposition was convincing. In October of 1856, the jury decided in Letitia's favor, and she was awarded $\$ 1200$ plus the cost of her court fees.

The importance of the testimony and the second suit more generally was to prove that Letitia owned property - very valuable property - separate from David. The cow represented income potential for Letitia, an investment into her future. Might this same cow have been the one that infamously saved David in the middle of a blinding snowstorm? That much isn't known, but Walker's deposition was enough to show the jury that the cow and all offspring were unfairly taken from her. If Letitia had been David's legally recognized wife, she would not have been able to make the same claim. There were other reasons to sidestep the role of widow. If Letitia had claimed in court that she had been David's wife, she would have been required to prove it. The burden of proof would have been extremely heavy and inherently risky. Any woman in court would have been subject to intense scrutiny as to her respectability. To claim the status of a common law wife would mean admitting a sexual relationship and relying on the court to believe it existed within its proper place: the marital compact. Yet, if it backfired, the sexual relationship already admitted to would become illicit, with no chance to claim a widow's rights. For Letitia, that risk was substantially greater. In cases where common law marriages showed up in courts, the legitimacy of the marriage might come down to the testimony of others as to the nature of one's relationship, a deep dive into the most private and intimate parts of one's life.

${ }^{236}$ Ibid. 
The case of Alfred and Leah Foster provides an illuminating example of what might have been. ${ }^{237}$ Though the legal proceedings happen in Texas a decade after Letitia's court case, the similarities are informative. Leah had been enslaved by Alfred Foster until he legally manumitted her, had several of his children and moved west with him, from Mississippi to Texas, where they lived until his death. Unlike the Carsons, though, when Alfred Foster died, he left most of his estate to Leah. Despite a clearintentioned will, a White neighbor had been made co-executor of the estate and auctioned off her inheritance. She sued the man in court as Alfred's widow. Central to her case was providing proof that she and Alfred lived as a married couple. As Pascoe explains, Leah's lawyers recognized that "proving a marriage often came down to showing the intentions of the man within it," and so testimony included descriptions of where Leah slept and how often she and Alfred slept together. ${ }^{238}$ Together with other factors, the judge ruled in Leah's favor. Leah took a chance and it paid off. It might not have. Even though Alfred Foster never called Leah his wife - not even in his will - there was apparently enough evidence for the judge to believe that Alfred considered her such.

Letitia did not have the benefit of a will. Had she claimed a widow's inheritance, she might have had to endure the indignity of proving to the state the details of her sexual life. It might have been a useless exercise anyway. Letitia already had an idea of how the state saw her relationship with David. When the two moved to Oregon, they made a provisional land claim of 640 acres in the Soap Creek Valley. With territorial status, all

\footnotetext{
${ }^{237}$ I borrow here from Peggy Pascoe's description and research on the story of Leah and Alfred Foster in the first chapter of her book What Comes Naturally. The case bookends the chapter and underscores the point Pascoe makes about the intersection of gender and miscegenation laws. Pascoe, What Comes Naturally, 17-46.

${ }^{238}$ Pascoe, What Comes Naturally, 34.
} 
claims were voided. When Congress passed the Oregon Donation Land Claim Act, David's claim was cut in half. He was given back 320 acres of his original square mile, the most a single White man could claim. Had David been married to a White woman, she would have been eligible for an additional 320 acres and they might have kept their original claim. Yet, with the 320 -acre land grant came a very significant message: in the eyes of the territorial government, David Carson was not married. Letitia and her lawyers might not have needed any other information while crafting their strategy.

In the end, Letitia staked her claims on a contractual agreement between employer and employee. To assume that her claim in court was genuinely reflective of how she viewed her own life would be to deny her dimension, nuance, or deliberation. The stakes and risk inherent for Letitia in taking a stance against an influential White man in the community were staggering. Despite the increasingly restrictive racial codes Letitia navigated a political and legal environment that was being built to disenfranchise her. But the apparatus of the racist state hadn't fully matured or gained the structure it would in the ensuing years. There was still wiggle room and Letitia successfully found a way to inhabit and exploit it. She told the court of the agreement "that in consideration I would live with and work for the said David Carson for and during the time of his natural life that at his decease he would make me his sole heir or that he would give me his entire property," and that because of this agreement, "I continued to live with and work for the said David." ${ }^{239}$ Letitia invoked the imagery of mutual obligation, encompassing both of the socially acceptable relationships upon which antebellum American life was built. The agreement described by Letitia evoked the mutual responsibilities meant to define both

${ }^{239}$ Letitia Carson vs. Greenberry Smith, Carson Complaint. 
marriage and slavery. Though she claimed a place in neither institution, her statement appealed to both. 


\section{Epilogue}

Even after two unlikely legal victories, Letitia continued to outmaneuver the White supremacy upon which the state of Oregon - and the entire nation - was built. Again, Letitia exercised her right to self-determination when she applied for free federal land under the Homestead Act as a "widow." Given her assertion that she was David Carson's employee during the court case against Greenberry Smith, it seems she contradicted herself, suggesting one of her claims was intentionally false. Though, just as she did in Benton County probate court, Letitia likely used the political and social context surrounding her to inform her approach to staking her own claim as a landed settler in her own right.

In the first few years after David's death, Letitia moved to Douglas County, over 100 miles away from Benton County and her life with David. She can be tracked for a few years in the upper Cow Creek Valley. She and her son Adam, who by now was known as Jack, lived with Donation Land Claim settler Hardy Elliff and his wife Melvina, at least for a short while. According to Bess A. Clough's biographical sketch of her grandfather, Hardy, "Aunt Tish and small son Jack, freed Negro slaves, came to be with grandmother and stayed a year or so. Grandmother's oldest girl, Alice, was born in the fall of 1854 and Aunt Tish took care of her during delivery..." ${ }^{240}$ She and her son lived with the Elliff's during the Rogue River Indian Wars, a series of conflicts between settlers and the Native American tribes in Southern Oregon in 1855-1856. According to the Cow Creek tribe, after broken treaties and violence perpetrated by White settlers and

${ }^{240}$ Bess A. Clough, "Hardy Crier Elliff," The Umpqua Trapper 16, no. 1 (1980): 36. 
miners, they believed their existence was threatened. ${ }^{241}$ The Cow Creek fought back and during the fall of 1855, Letitia and the Elliffs left the area for safety. They spent nine months at the Galesville Stockade while the conflict flared. ${ }^{242}$ Interestingly, this time frame corresponds with her initial court case, and explains why her lawyer, Andrew Thayer, often had to represent her in court. From other oral recollections and written remembrances, it seems "Aunt Tish," as she was known in Douglas County, served as community midwife. ${ }^{243}$ It appears Martha was not with her mother and brother during their stay with the Elliffs, and not much is known about her until 1868, when she married Narcisse Lavadore, a member of the Walla Walla tribe.

However, Letitia again showed up in official records in 1863, when she filed a Homestead Act claim, just months after the historic act was passed in Congress. After years of squatters claiming land in the far reaches of the American frontier, and the pressure by many Northern states to distribute free land, Abraham Lincoln signed the Homestead Act into law in May, $1862 .{ }^{244}$ Most Southern states were opposed to granting free land in the West, for fear that it would fill up with anti-slavery settlers, but once they had seceded, passage of the act through Congress was quick. ${ }^{245}$ The new law required applicants to pay a filing fee, live on the land and demonstrate improvements including building a structure. Afterward, they were free to claim title. The Homestead Act was a watershed moment in the settlement of the West, spanning more than 123 years and

\footnotetext{
${ }^{241}$ Cow Creek Band of Umpqua Tribe of Indians, "Tribal Story: First Contact With Euro-American Settlers," accessed August 30, 2021, https://www.cowcreek-nsn.gov/tribal-story/tribal-story-contact/. ${ }^{242}$ Clough, "Hardy Crier Elliff," 38.

${ }^{243}$ George B. Abdill, "Letitia Carson, Pioneer Black Woman," The Umpqua Trapper 18, no. 3 (1982): 67.

${ }^{244}$ Chused, "The Oregon Donation Land Act," 55.

${ }^{245}$ McPherson, Battle Cry of Freedom, 193.
} 
eventually doling out over 10 percent of U.S. land. ${ }^{246}$ Though more than two million homesteaders eventually made claims under the Homestead Act, Letitia Carson was one of the first.

The new law was unique in its relatively lax application requirements. The act was open to any head of a household over 21 who was a citizen of the United States. Non-White immigrants and Native Americans were expressly excluded as they were not eligible for citizenship, but single women and widows were included, a striking shift from the Oregon Donation Land Claim Act. ${ }^{247}$ It has also often been held up as a racially progressive piece of legislation given the lack of explicit racial requirements. Several Radical Republican senators had argued for the removal of racial restrictions for years. ${ }^{248}$ Prior to its passage, Edward Wade of Ohio argued that African Americans should be able to take advantage of any homestead act to prove once and for all their right to equality. He suggested Congress "Throw open these Territories and permit the colored man to depart from the States which oppress him and locate himself where he can have the opportunity to prove his equality with the whites, or make his inequality manifest beyond controversy." ${ }^{249}$ Wade and other supporters were eventually successful.

However, the lack of express racial restriction did not mean that the act was immediately available for free Blacks. Indeed, after the Civil War, many free Blacks were able to take advantage of the act - as well as with the Southern Homestead Act of 1866 -

\footnotetext{
${ }^{246}$ Benjamin Todd Arrington, “'Free Homes for Free Men': A Political History of the Homestead Act, 1774-1863" (Ph.D., United States -- Nebraska, The University of Nebraska - Lincoln, 2012), 224, accessed August 30, 2021, http://www.proquest.com/docview/1009080583/abstract/12AE84364AC34017PQ/1. ${ }^{247}$ Coleman, "We'll All Start Even," 427.

${ }^{248}$ Eric Foner, Free Soil, Free Labor, Free Men, 296.

${ }^{249}$ Congressional Globe, 33rd Cong., 1st Sess., 1072, accessed August 31, 2021, https://memory.loc.gov/cgi-bin/ampage? collId=1lcg\&fileName=034/llcg034.db\&recNum=361.
} 
and to try their hand at homesteading. ${ }^{250}$ However, when Letitia Carson visited the Land Office at Roseburg, Oregon in June of 1863, the Civil War was still raging, and the Dred Scott decision, passed by the Supreme Court in 1857, still held true: no one with African heritage was considered an American citizen. ${ }^{251} 252$

Letitia Carson filed her application as a "head of a family being a widow having two children." 253 She also had to swear to citizenship, something that in reality was roughly a matter of opinion. Though Black Americans would receive citizenship with the Civil Rights Act of 1866 and the passage of the 14th Amendment in 1868, there existed much confusion in the early 1860 s as to whether free Blacks could be considered citizens. Edward Bates, Attorney General under Abraham Lincoln, published an opinion in 1862, contradicting the Supreme Court's Dred Scott decision and essentially asserting that free Blacks were citizens if they were born in the United States. "The Constitution... is silent about race as it is about color. Our nationality was created and our political government exists by written law, and inasmuch as that law does not exclude persons of that descent, and as its terms are manifestly broad enough to include them, it follows inevitably that such persons, born in the country, must be citizens..." he opined. ${ }^{254}$ Writing a letter to Salmon P. Chase, secretary of the Treasury in November 1862, he concluded thusly, "And now, upon the whole matter, I give it as my opinion that the free man of color

\footnotetext{
${ }^{250}$ For more: Richard Edwards, "African Americans and the Southern Homestead Act," Great Plains Quarterly 39, no. 2 (2019): 103-29, https://doi.org/10.1353/gpq.2019.0018.

251 "Homestead Act Affidavit," June 17th, 1863.

${ }^{252}$ John S. Vishneski, "What the Court Decided in Dred Scott v. Sandford," The American Journal of Legal History 32, no. 4 (1988): 373-90, https://doi.org/10.2307/845743.

253 "Homestead Act Affidavit", June 17th, 1863.

${ }^{254}$ Edward Bates, Opinion of Attorney General Bates on Citizenship (Government Printing Office, 1862), 15, http://archive.org/details/opinionattorney01bategoog.
} 
mentioned in your letter, if born in the United States is a citizen of the United States."255 The conclusion, though widely disseminated, did little to clarify what would eventually require an additional Constitutional amendment. Between 1862 and 1866, then, free Blacks' ability to claim citizenship was murky at best.

At the same time, Oregon passed even more racially restrictive laws, including formally outlawing interracial marriage. Oregon also passed a law requiring all Blacks, Chinese, Hawaiians to pay an annual poll tax of five dollars. If not paid, they could be pressed into service. ${ }^{256}$ Clearly anti-Black sentiment was alive and well in Oregon in 1862. Just as existed when Letitia claimed an employee's status in the first court case against Greenberry Smith, overlapping and often contradictory laws and proclamations and resolutions meant that Letitia needed to choose her approach wisely. By no means guaranteed to be seen as a citizen, even though she had been legally classified as a free woman, Letitia chose instead to file her claim as a widow.

In conclusion, it is similarly impossible to know why Letitia chose to file contradictory claims. What we know, however, is that in both instances, Letitia emerged victorious. Just like her legal victory, her successful Homestead Act claim is proof that multiple conflicting realities existed in antebellum Oregon, and indeed across the United States. Therefore, it is essential for historians to interrogate her strategies and her eventual success for what they can illuminate about the epically influential decades through which Letitia made her mark on Oregon history. While White supremacy provided the foundation for the settlement of the state, an incredibly determined woman

${ }^{255}$ Ibid, 27.

${ }^{256}$ McLagan, A Peculiar Paradise, 64. 
waded through the various power structures and successfully used the system intended to deny her power against itself. Throughout her life, Letitia Carson resisted attempts to categorize and control her, eventually laying claim to her own piece of the promise of the American West: land, space, and freedom. She lived the rest of her life on her own land and on her own terms. 


\section{Bibliography}

Abdill, George B. "Letitia Carson, Pioneer Black Woman.” The Umpqua Trapper 18, no. 3 (1982): 67-71.

Arrington, Benjamin Todd. “'Free Homes for Free Men': A Political History of the Homestead Act, 1774-1863.” Ph.D., The University of Nebraska - Lincoln, 2012. Accessed August 30, 2021.

http://www.proquest.com/docview/1009080583/abstract/12AE84364AC34017P $\underline{\mathrm{Q} / 1}$.

Alshaikhmubarak, Hazem, R. Richard Geddes, and Shoshana A. Grossbard. "Single Motherhood and the Abolition of Coverture in the United States." Journal of Empirical Legal Studies 16, no. 1 (March 2019): 94-118. https://doi.org/10.1111/jels.12210.

Barber, Katrine. "'We Were at Our Journey's End': Settler Sovereignty Formation in Oregon.” Oregon Historical Quarterly 120, no. 4 (Winter 2019): 382-411.

Bardaglio, Peter. "'Shamefull Matches': The Regulation of Interracial Sex and Marriage in the South before 1900." In Sex, Love, Race: Crossing Boundaries in North American History, edited by Martha Elizabeth Hodes, 112-138. New York: University Press, 1999.

Basch, Norma. "Invisible Women: The Legal Fiction of Marital Unity in NineteenthCentury America.” Feminist Studies 5, no. 2 (1979): 346-66. https://doi.org/10.2307/3177600.

Bergquist, James M. "The Oregon Donation Act and the National Land Policy." Oregon Historical Quarterly 58, no. 1 (1957): 17-35. https://www.jstor.org/stable/20612302.

Berwanger, Eugene H. The Frontier Against Slavery: Western Anti-Negro Prejudice and the Slavery Extension Controversy. Urbana: University of Illinois Press, 1967.

Binder, Andrea Mary. “'Deep Is the Grave, and Silent:' Death and Mourning on the Oregon-California Trails.” M.A., University of Wyoming, 2011. Accessed September 10, 2021. http://www.proquest.com/docview/866190821/abstract/4E4483F838304452PQ/ $\underline{1 .}$

Blair, Karen J. Women in Pacific Northwest History: An Anthology. Seattle: University of Washington Press, 1988. 
Block, Sharon. "Lines of Color, Sex, and Service: Comparative Sexual Coercion in Early America." In Sex, Love, Race: Crossing Boundaries in North American History, edited by Martha Elizabeth Hodes, 141-163. New York: University Press, 1999.

Carey, Charles. The Oregon Constitution and Proceedings and Debates of the Constitutional Convention of 1857. Salem, Or.: State Printing Department, 1926.

Carlin, Amanda. "The Courtroom as White Space: Racial Performance as Noncredibility." UCLA Law Review 63, no. 2. (2016): 452-484. https://www.uclalawreview.org/courtroom-white-space-racial-performancenoncredibility/.

Carter, Robert W. "'Sometimes When I Hear the Winds Sigh': Mortality on the Overland Trail." California History (San Francisco) 74, no. 2 (1995): 146-61. https://doi.org/10.2307/25177489.

Child, Sargent B, T J Edmonds, Walter Kiplinger, Harold D Grey, Florence Kerr, Mary H Isham, and Gladys E Everett. "Historical Records Survey Project: Benton County Records," n.d., 257.

Chused, Richard H. "The Oregon Donation Act of 1850 and Nineteenth Century Federal Married Women's Property Law." Law and History Review 2, no. 1 (1984): 44-78. https://doi.org/10.2307/743910.

Clayton, Daniel. "The Creation of Imperial Space in the Pacific Northwest." Journal of Historical Geography 26, no. 3 (2000): 327-50.

Clinton, Catherine, and Michele Gillespie. The Devil's Lane: Sex and Race in the Early South. New York: Oxford University Press, 1997.

Clough, Bess A. "Hardy Crier Elliff.” The Umpqua Trapper 16, no. 1 (1980): 36.

Coleman, Kenneth. "'Dangerous Subjects': James D. Saules and the Enforcement of the

Color Line in Oregon.” Corvallis: Oregon State University Press. 2017.

Coleman, Kenneth R. “We'll All Start Even': White Egalitarianism and the Oregon Donation Land Claim Act." Oregon Historical Quarterly 120, no. 4 (2019): 414-39. https://doi.org/10.5403/oregonhistq.120.4.0414.

Cummins, Sarah J. Autobiography and Reminiscences of Sarah J. Cummins. La Grande, Or.: La Grande Printing Co., 1914. http://hdl.handle.net/2027/uc2.ark:/13960/t0zp3z41c. 
Earle, Jonathan H. Jacksonian Antislavery and the Politics of Free Soil, 1824-1854. Chapel Hill: The University of North Carolina Press, 2004. http://ebookcentral.proquest.com/lib/psu/detail.action?docID=413263.

Faragher, John Mack. "Midwestern Families in Motion: Women and Men on the Overland Trail to Oregon and California, 1843-1870.” Ph.D., Yale University, 1977. Accessed September 10, 2021. http://www.proquest.com/docview/302861507/citation/8FAB84C35C8D4B75P $\underline{\mathrm{Q} / 1}$.

Foner, Eric. Free Soil, Free Labor, Free Men: The Ideology of the Republican Party Before the Civil War. Cary: Oxford University Press, 1995. http://ebookcentral.proquest.com/lib/psu/detail.action?docID=694007.

Gordon-Reed, Annette. Thomas Jefferson and Sally Hemings: An American Controversy. Charlottesville: University Press of Virginia, 1997.

Graaf, Lawrence B. de. "Race, Sex, and Region: Black Women in the American West, 1850-1920.” Pacific Historical Review 49, no. 2 (1980): 285-313. https://doi.org/10.2307/3638903.

Hardaway, Roger D. “African-American Women on the Western Frontier.” Negro History Bulletin 60, no. 1 (1997): 8-13. http://www.jstor.org/stable/24766796.

Hill, William E. The Oregon Trail, Yesterday and Today: A Brief History and Pictorial Journey along the Wagon Tracks of Pioneers. Rev. ed. Caldwell, Idaho: Caxton Printers, 2000.

Hine, Darlene Clark. “'Ar'n't I a Woman?: Female Slaves in the Plantation South': Twenty Years After." The Journal of African American History 92, no. 1 (2007): 13-21. http://www.jstor.org/stable/20064151.

_. "Rape and the Inner Lives of Black Women in the Middle West." Signs 14, no. 4 (1989): 912-20. http://www.jstor.org/stable/3174692.

Hodes, Martha. White Women, Black Men: Illicit Sex in the Nineteenth-Century South. New Haven: Yale University Press, 1999. http://ebookcentral.proquest.com/lib/psu/detail.action?docID=3421444.

Holman, Frederick V. "A Brief History of the Oregon Provisional Government and What Caused Its Formation." The Quarterly of the Oregon Historical Society 13, no. 2 (1912): 89-139. https://www.jstor.org/stable/20609900. 
Huebner, Timothy S. “'In Defiance of Judge Taney': Black Constitutionalism and Resistance to Dred Scott." Journal of Supreme Court History 45, no. 3 (2020): 215-35. https://doi.org/10.1111/jsch.12245.

Hurtado, Albert L. Intimate Frontiers: Sex, Gender, and Culture in Old California. Albuquerque: University of New Mexico Press, 1999.

Jagodinsky, Katrina. Legal Codes and Talking Trees: Indigenous Women's Sovereignty in the Sonoran and Puget Sound Borderlands, 1854-1946. Lamar Series in Western History. New Haven: Yale University Press, 2016.

Johannsen, Robert W. "The Kansas-Nebraska Act and the Pacific Northwest Frontier." Pacific Historical Review 22, no. 2 (1953): 129-41. https://doi.org/10.2307/4492028.

Johnson, David Alan. Founding the Far West: California, Oregon, and Nevada, 1840-1890. Berkeley: University of California Press, 1992. http://stats.lib.pdx.edu/proxy.php?url=http://search.ebscohost.com/login.aspx?di $\underline{\text { rect }=\text { true } \& \mathrm{db}=\text { nlebk\&AN=21226\&site }=\text { ehost-live. }}$.

Johnson, Walter. "The Slave Trader, the White Slave, and the Politics of Racial Determination in the 1850s." The Journal of American History 87, no. 1 (2000): 13-38. https://doi.org/10.2307/2567914.

Jones, Bernie D., Paul Finkelman, Kermit Hall, and Timothy S. Huebner. Fathers of Conscience: Mixed-Race Inheritance in the Antebellum South. Athens: University of Georgia Press, 2009. http://ebookcentral.proquest.com/lib/psu/detail.action?docID=3038991.

Labbe, Jim M. “The Colored Brother's Few Defenders: Oregon Abolitionists and Their Followers." Oregon Historical Quarterly 120, no. 4 (2019): 440-67. https://doi.org/10.5403/oregonhistq.120.4.0440.

Lansing, Ronald B. Nimrod: Courts, Claims, and Killing on the Oregon Frontier. Pullman: Washington State University Press, 2005.

Lemire, Elise. Miscegenation: Making Race in America. Philadelphia: University of Pennsylvania Press, 2009. http://ebookcentral.proquest.com/lib/psu/detail.action?docID=3441458.

Lockley, Fred. "Some Documentary Records of Slavery in Oregon." The Quarterly of the Oregon Historical Society 17, no. 2 (1916): 107-15. https://www.jstor.org/stable/20610035. 
- "The Case of Robin Holmes vs. Nathaniel Ford." The Quarterly of the Oregon Historical Society 23, no. 2 (1922): 111-37.

https://www.jstor.org/stable/20610207.

Mcclintock, Thomas C. "James Saules, Peter Burnett, and the Oregon Black Exclusion Law of June 1844.” The Pacific Northwest Quarterly 86, no. 3 (1995): 121-30. https://www.jstor.org/stable/40491550.

McLagan, Elizabeth. A Peculiar Paradise: A History of Blacks in Oregon, 17881940. 1st ed. Portland, Or.: Georgian Press, 1980.

McLaurin, Melton A. Celia, a Slave. Athens: University of Georgia Press, 1991. http://ebookcentral.proquest.com/lib/psu/detail.action?docID=3038977.

Minto, John. "Reminiscences of Experiences on the Oregon Trail in 1844.--II." The Quarterly of the Oregon Historical Society 2, no. 3 (1901): 209-54. https://www.jstor.org/stable/20609503.

Moore, Shirley Ann Wilson. Sweet Freedom's Plains: African Americans on the Overland Trails, 1841-1869. Race and Culture in the American West; v. 12. Norman, OK: University of Oklahoma Press, 2016.

Nokes, R. Gregory. Breaking Chains: Slavery on Trial in the Oregon Territory. Corvallis, OR: Oregon State University Press, 2013.

Oregon Secretary of State Archives Division. "Early Oregonian Person Profile." Accessed August 20, 2021. https://secure.sos.state.or.us/prs/profile.do?ancRecordNumber=94926.

Oregon Northwest Black Pioneers Organization. Perseverance: A History of African Americans in Oregon's Marion and Polk Counties. Salem, Or.: Oregon Northwest Black Pioneers, 2011.

Pascoe, Peggy. "Race, Gender, and Intercultural Relations: The Case of Interracial Marriage." Frontiers: A Journal of Women Studies 12, no. 1 (1991): 5-18. https://doi.org/10.2307/3346572.

-What Comes Naturally: Miscegenation Law and the Making of Race in America. Oxford, England: Oxford University Press, 2009.

Perry, James R., Richard H. Chused, and Mary DeLano. "The Spousal Letters of Samuel R. Thurston, Oregon's First Territorial Delegate to Congress: 18491851.” Oregon Historical Quarterly 96, no. 1 (1995): 4-79. http://www.jstor.org/stable/20614637. 
Petterson, Jay R. "A Return to Filius Nullius.” North Dakota Law Review 48, no. 1 (1971): 59-91.

Prescott, Cynthia Culver. "Gender and Generation on the Far Western Frontier." Women's Western Voices, edited by Laura Woodworth-Ney. Tucson: University of Arizona Press, 2007.

Rhyne, J. Michael. “'Conduct ... Inexcusable and Unjustifiable': Bound Children, Battered Freedwomen, and the Limits of Emancipation in Kentucky's Bluegrass Region." Journal of Social History; Oxford 42, no. 2 (Winter 2008): 319-340, 547-548. http://dx.doi.org.proxy.lib.pdx.edu/10.1353/jsh.0.0111.

Richard, K. Keith. "Unwelcome Settlers: Black and Mulatto Oregon Pioneers." Oregon Historical Quarterly 84, no. 1 (1983): 29-55. https://www.jstor.org/stable/20613888.

Riley, Glenda. "American Daughters: Black Women in the West." Montana: The Magazine of Western History 38, no. 2 (1988): 14-27. https://www.jstor.org/stable/4519131.

Robertson, James Rood. "The Genesis of Political Authority and of a Commonwealth Government in Oregon." The Quarterly of the Oregon Historical Society 1, no. 1 (1900): 3-59. http://www.jstor.org/stable/20609444.

Robbins, Horace H., and Francis Deák. "The Familial Property Rights of Illegitimate Children: A Comparative Study." Columbia Law Review 30, no. 3 (1930): 30829. https://doi.org/10.2307/1115305.

Robbins, Roy M. "The Federal Land System in an Embryo State." Pacific Historical Review 4, no. 4 (1935): 356-75. https://doi.org/10.2307/3634046.

Robbins, William G. Oregon: This Storied Land. Second edition. Seattle: University of Washington Press, 2020.

Ronda, James P. Astoria \& Empire. Lincoln: University of Nebraska Press, 1990.

Ruffin, Herbert G., and Dwayne Mack. "Freedom's Racial Frontier: African Americans in the Twentieth-Century West." Race and Culture in the American West; v. 13. Norman: University of Oklahoma Press, 2018.

Shammas, Carole. "Re-Assessing the Married Women's Property Acts." Journal of Women's History 6, no. 1 (1994): 9-30. https://doi.org/10.1353/jowh.2010.0269. 
Smith, Stacey L. Freedom's Frontier: California and the Struggle over Unfree Labor, Emancipation, and Reconstruction. Chapel Hill: The University of North Carolina Press, 2013.

Smith, Wilmer C. The Smith Chronicle: Two Centuries of an American Farm Family. Self-published, 1973.

Sohoni, Deenesh. "Unsuitable Suitors: Anti-Miscegenation Laws, Naturalization Laws, and the Construction of Asian Identities." Law \& Society Review 41, no. 3 (2007): 587-618. https://www.jstor.org/stable/4623396.

Statistics, United States Bureau of Labor, Estelle M. (Estelle May) Stewart, and Jesse Chester Bowen. "History of Wages in the United States From Colonial Times to 1928." Bulletin of the United States Bureau of Labor Statistics, No. 499. October 1, 1929. https://fraser.stlouisfed.org/title/history-wages-unitedstates-colonial-times-1928-4067.

Stevenson, Brenda E. "What's Love Got to Do With It? Concubinage and Enslaved Women and Girls in the Antebellum South." The Journal of African American History 98, no. 1 (2013): 99-125.

https://doi.org/10.5323/jafriamerhist.98.1.0099.

Suval, John. "The Nomadic Race to Which I Belong': Squatter Democracy and the Claiming of Oregon." Oregon Historical Quarterly 118, no. 3 (September 22, 2017): 306-38. https://go-galecom.proxy.lib.pdx.edu/ps/i.do?p=AONE\&sw $=w \& i s s n=00304727 \& v=2.1 \& i t=r$ $\underline{\text { \&id }=\text { GALE } \% 7 C A 559357658 \& \text { sid }=\text { googleScholar\&linkaccess }=\text { abs. }}$.

Taylor, Quintard. In Search of the Racial Frontier: African Americans in the American West, 1528-1990. 1st ed. New York: Norton, 1998.

Taylor, Quintard, and Shirley Ann Wilson Moore. African American Women Confront the West, 1600-2000. First paperback edition. Norman, Oklahoma: University of Oklahoma Press, 2008.

Thoennes, Philip, and Jack Landau. "Constitutionalizing Racism: George $\mathrm{H}$. Williams's Appeal for a White Utopia." Oregon Historical Quarterly 120, no. 4 (2019): 468-87.

Unruh, John David. The Plains Across: The Overland Emigrants and the TransMississippi West, 1840-60. Champaign: University of Illinois Press, 1993.

United States, C. C. McCain, Roland P. Falkner, and Nelson W. Aldrich. Wholesale Prices, Wages, and Transportation. Report by Mr. Aldrich, from the Committee on Finance, March 3, 1893. 52d Cong., 2d Sess. Senate. Rept. 1394. 
Washington: Govt. Print. Off., 1893.

https://catalog.hathitrust.org/Record/001309548.

Van Tassel, Emily F. "Women, Property, and Politics in Nineteenth-Century Law." Edited by Norman Basch. Reviews in American History 11, no. 3 (1983): 374 80. https://doi.org/10.2307/2702468.

Vishneski, John S. "What the Court Decided in Dred Scott v. Sandford." The American Journal of Legal History 32, no. 4 (1988): 373-90. https://doi.org/10.2307/845743.

Wells, Charles. Enumeration of the Inhabitants of Benton County, Oregon Territory, as Taken by Charles Wells, Assessor for the Year 1854. Copied from the Original in the

Benton County, Oregon. Corvallis, 1947. https://ia802307.us.archive.org/29/items/EnumerationOfTheInhabitantsOfBento nCounty $1854 /$ Enumeration $\% 20$ of $\% 20$ the $\% 20$ inhabitants $\% 20$ of $\% 20$ Benton $\% 20$ County\%201854.pdf

West, Elliott. The Last Indian War: The Nez Perce Story. Cary: Oxford University Press, 2011. http://ebookcentral.proquest.com/lib/psu/detail.action?docID=431369.

Whaley, Gray H. "Oregon, Illahee, and the Empire Republic: A Case Study of American Colonialism, 1843-1858." Western Historical Quarterly 36, no. 2 (2005): 157-78. https://doi.org/10.2307/25443145.

White, Deborah G. Ar'n't I a Woman?: Female Slaves in the Plantation South. Rev. ed. New York: W.W. Norton, 1999.

Williams, George H. "Political History of Oregon from 1853 to 1865." The Quarterly of the Oregon Historical Society 2, no. 1 (1901): 1-35. http://www.jstor.org/stable/20609486.

Woodward, Walter Carleton. "The Rise and Early History of Political Parties in Oregon II: Part II: Period of the Territorial Government, Political Organization." The Quarterly of the Oregon Historical Society 12, no. 1 (1911): 33-86. http://www.jstor.org/stable/20609861.

Zybach, Bob. "Strangely Absent from History: Carson vs. Smith, 1852-1857," Oregon State Bar Bulletin 77, No. 1: 24-28. 


\section{Primary Sources}

"Appraiser Statements," 1852 Benton County Probate Court, http://www.orww.org/History/Letitia_Carson/Documentation/18521857 Oregon_Probate/18521207_Appraiser_Statements.jpg

"Estate Appraisal," 1852 Benton County Probate Court, http://www.orww.org/History/Letitia_Carson/Documentation/18521857 Oregon Probate/18521207 Estate Appraisal-1.jpg.

"Homestead Act Affidavit", June 17th, 1863. http://www.orww.org/History/Letitia_Carson/Documentation/18531922 Douglas_County/18630617_Affidavit.jpg

Greenberry Smith, "Estate Sale Record," 1852 Benton County Probate Court, http://www.orww.org/History/Letitia_Carson/Documentation/18521857 Oregon_Probate/18530104_Estate_Sale-1.jpg

Greenberry Smith, "Estate Sale Record," 1853 Benton County Probate Court, http://www.orww.org/History/Letitia Carson/Documentation/18521857 Oregon Probate/18530104 Estate Sale-1.jpg.

Greenberry Smith, "Probate Document," 1852 Benton County Probate Court, http://www.orww.org/History/Letitia_Carson/Documentation/18521857 Oregon_Probate/18521125_Administrator_Smith-1.jpg

Letitia Carson vs. Greenberry Smith, “Answer Greenberry Smith,” 1854 Benton County Probate Court, http://www.orww.org/History/Letitia_Carson/Documentation/18541857_Carson_vs_Smith/18541010_Answer_GB_Smith-1.jpg.

Letitia Carson vs. Greenberry Smith, "Bill for Andrew Carson Subpoena," 1854 Benton County Probate Court, http://www.orww.org/History/Letitia_Carson/Documentation/18541857 Carson_vs_Smith/18540313_Subpoena_A_Carson_Bill.jpg.

Letitia Carson vs. Greenberry Smith, "Carson Complaint," 1854 Benton County Probate Court, http://www.orww.org/History/Letitia_Carson/Documentation/18541857 Carson_vs_Smith/18540227_Complaint_L_Carson-1.jpg.

Letitia Carson vs. Greenberry Smith, "Carson Complaint," 1854 Benton County Probate Court, http://www.orww.org/History/Letitia Carson/Documentation/18541857 Carson vs Smith/18540227 Complaint L Carson-1.jpg 
Letitia Carson vs. Greenberry Smith, "Carson Statement,” 1854 Benton County Probate Court, http://www.orww.org/History/Letitia_Carson/Documentation/18541857_Carson_vs_Smith/18540313_Statement_L_Carson-1.jpg.

Letitia Carson vs. Greenberry Smith, “Greenberry Smith Answer,” 1854 Benton County Probate Court, http://www.orww.org/History/Letitia Carson/Documentation/18541857 Carson_vs_Smith/18541010_Answer_GB Smith-1.jpg.

Letitia Carson vs. Greenberry Smith, "Greenberry Smith Answer,” 1854 Benton County Probate Court, http://www.orww.org/History/Letitia_Carson/Documentation/18541857 Carson_vs_Smith/18541010_Answer_GB Smith-2.jpg.

Letitia Carson vs. Greenberry Smith, "Judgment Bill,” 1855 Benton County Probate Court, http://www.orww.org/History/Letitia_Carson/Documentation/18541857 Carson_vs Smith/18550624 Judgment_Bill.jpg.

Letitia Carson vs. Greenberry Smith, "Judgment," 1856 Benton County Probate Court, http://www.orww.org/History/Letitia Carson/Documentation/18541857 Carson_vs_Smith/18561020_Judgment_\$1200.jpg.

Letitia Carson vs. Greenberry Smith, "Kelsay Statement," 1854 Benton County Probate Court, http://www.orww.org/History/Letitia_Carson/Documentation/18541857 Carson_vs_Smith/18540300_Kelsay_Statement-1.jpg.

Letitia Carson vs. Greenberry Smith, "Letitia Carson Complaint,” 1854 Benton County Probate Court, http://www.orww.org/History/Letitia_Carson/Documentation/18541857 Carson vs Smith/18540922 L Carson Complaint.jpg.

Letitia Carson vs. Greenberry Smith, "Letitia Carson Labor Bill,” 1854 Benton County Probate Court, http://www.orww.org/History/Letitia_Carson/Documentation/18541857 Carson_vs_Smith/18540712_L_Carson_Labor_Bill.jpg.

Letitia Carson vs. Greenberry Smith, "Motion Thayer," 1854 Benton County Probate Court, http://www.orww.org/History/Letitia_Carson/Documentation/18541857 Carson_vs_Smith/18541007_Motion_Thayer.jpg.

Letitia Carson vs. Greenberry Smith, "Notice to Greenbury Smith," 1854 Benton County Probate Court, 
http://www.orww.org/History/Letitia_Carson/Documentation/18541857_Carson_vs_Smith/18540228_Notice_Smith.jpg.

Letitia Carson vs. Greenberry Smith, "Response Smith,” 1855 Benton County Probate Court, http://www.orww.org/History/Letitia_Carson/Documentation/18541857 Carson vs Smith/18551004 Response Smith-1.jpg.

Letitia Carson vs. Greenberry Smith, "Response Thayer," 1854 Benton County Probate Court, http://www.orww.org/History/Letitia_Carson/Documentation/18541857_Carson_vs_Smith/18541011_Response_Thayer-1.jpg.

Letitia Carson vs. Greenberry Smith, "Subpoena Greenberry Smith,” 1854 Benton County Probate Court, http://www.orww.org/History/Letitia Carson/Documentation/18541857 Carson_vs Smith/18540922 Subpoena GB Smith.jpg.

Letitia Carson vs. Greenberry Smith, "Subpoena Writsman, et al," 1854 Benton County Probate Court, http://www.orww.org/History/Letitia Carson/Documentation/18541857_Carson_vs_Smith/18541009_Subpoena_Writsman_et_al.jpg.

Letitia Carson vs. Greenberry Smith, "Thayer Complaint," 1855 Benton County Probate Court, http://www.orww.org/History/Letitia_Carson/Documentation/18541857_Carson_vs_Smith/18550802_Complaint_Thayer-1.jpg.

Letitia Carson vs. Greenberry Smith, “Thayer Testimony,” 1854 Benton County Probate Court, http://www.orww.org/History/Letitia Carson/Documentation/18541857 Carson vs Smith/18540922 Testimony Thayer.jpg.

Letitia Carson vs. Greenberry Smith, “Thayer Testimony,” 1855 Benton County Probate Court, http://www.orww.org/History/Letitia Carson/Documentation/18541857_Carson_vs_Smith/18550921_Testimony_Thayer-1.jpg

Letitia Carson vs. Greenberry Smith, "Walker Deposition Bill," 1854 Benton County Probate Court, http://www.orww.org/History/Letitia Carson/Documentation/18541857 Carson_vs_Smith/18540327_Walker_Deposition_Bill.jpg.

Letitia Carson vs. Greenberry Smith, "Walker Deposition,” 1856 Benton County Probate Court, 
http://www.orww.org/History/Letitia Carson/Documentation/18541857_Carson_vs_Smith/18561008_Deposition_Walker-2.jpg.

Letitia Carson vs. Greenberry Smith, "Walker Deposition,” 1856 Benton County Probate Court, http://www.orww.org/History/Letitia Carson/Documentation/18541857 Carson vs Smith/18561008 Deposition Walker-1.jpg.

Debate of the House of Representatives, 28 May 1850, in Congressional Globe, 30 May 1850: 1079, col. 2. "A Century of Lawmaking for a New Nation: U.S. Congressional Documents and Debates, 1774 - 1875," accessed August 23, 2021, https://memory.loc.gov/cgi-bin/ampage.

Debate of the House of Representatives, 3 May 1854, in Congressional Globe: 33rd Congress, 1st Session, 1072, column 2, accessed August 31, 2021, https://memory.loc.gov/cgibin/ampage? collId $=1 \operatorname{lcg} \&$ fileName $=034 / 1 \operatorname{lcg} 034$. db\&recNum=361

Edward Bates. Opinion of Attorney General Bates on Citizenship. Government Printing Office, 1862. http://archive.org/details/opinionattorney01bategoog.

Surveyor General's Office. “Township No 10 South Range No 5 West Willamette Meridian" (Eugene: Surveyor General's Office, 1860).

\section{Newspapers}

“Cool!" The Oregon Statesman, July 14, 1855

"District Court Benton County.” The Oregon Statesman, Oct. 17, 1854.

“The African Race.” The Oregon Statesman, July 13, 1851.

The Oregon Statesman, December 22, 1857. 